



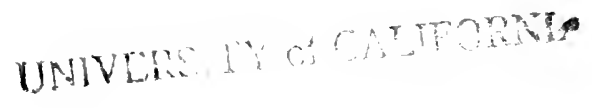





\section{THE AMERICAN TRANSPORTATION QUESTION}





\section{THE AMERICAN}

\section{TRANSPORTATION}

\section{QUESTION}

\section{BY}

\section{SAMUEL O. DUNN}

Editor of the Railway age Gazette; Lecturer on Transportation at NorthWestern UNIVERSity; MeMber of the IllinoIs Bar

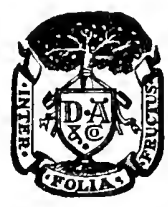

NEW YORK AND LONDON

D. APPLETON AND COMPANY 1912 
Copyrigit, 1912, BY

D. APILETON AND COMPANY

Publixhed Fobuary, rats

Printed in the Inited Sitates of America 


\section{P R EF A C E}

THE transportation problem has three vitally important factors: rates, service and financial return. Neither can be intelligently or equitably considered except with reference to the other two. The railway has a right to exact, and the public to require, fair and reasonable rates; but what are such rates depends largely on the service given for them and on the financial return received by the owners of the railway. The public has a right to demand safe, convenient and adequate service; but how safe, convenient and adequate a railway can make its service depends largely on its financial return, and this on what rates it can charge. The owners of the railways are legally entitled to a "fair return"; but this right is not absolute; it is conditioned on what kind of service is given and at what rates.

The fact that rates, service and return are thus related and interdependent is sometimes overlooked or disregarded. I have read articles and books on the "transportation problem" dealing exclusively with rates. This is like discussing whether the price of a suit of clothes or an automobile is reasonable regardless of how good a suit or automobile it is.

Most of the matter in the following pages was used 


\section{PREFACE}

in a series of lectures to the students of Northwestern University in April, 1911. In these lectures I tried to discuss rates, service and financial return, not por se, but with a view to their proper, and in the long run necessary, relation. Only, I believe, when railway officers, regulating authorities and the people consistently deal with them in this way will the transportation problem be satisfactorily and beneficially solved.

Until a few years ago the "railway problem" was regarded as chiefly the problem of suppressing unfair discrimination by railways between shippers. This is still one of the principal phases of the subject, and in these pages I have given considerable space to it. But the question of unfair discrimination has become relatively less important, and more attention and discussion are now being given to the basis on which rates as a whole should be made and regulated. Much consideration and discussion are also being devoted to the way in which our railways are managed; to whether they are efficiently operated and give as good service as they should; and, if not, to how the economy of their operations can be increased and their service improved. I have also given a good deal of space to these matters. They have not received as much attention in the past as they have deserved.

Until recently the American people did not believe in much regulation of industry. They thought that the less government and business had to do with each other the better, in the long run, it would be for both. In recent years there has been a remarkable change in public sentiment. This has resulted in a great in- 


\section{PREFACE}

crease of public regulation, especially of railways and other public utilities. Many think that we have gone too far in this direction. Many others think that we have not gone far enough. The former class will, perhaps, regard some of the views regarding regulation herein expressed as too radical. The latter class will consider them too conservative. In the present state of public opinion they are more apt to be criticised by most people as too conservative than as too radical. But when I compare them with views that have been expressed by men who for years have been leaders of public opinion in this country on economic, and especially on transportation, subjects, it is hard for me to regard myself as too conservative. President A. T. Hadley of Yale University said in an article on "The Ethics of Corporate Management," in the North American Review for January 18, 1907 :

Personally, I am one of those who look with serious distrust on each extension of political activity. I believe that the interstate commerce law did more to prevent wise railroad regulation than any other event in the history of the country. I think that the courts would have dealt with our industrial problems better than they have done if the antitrust act had never been passed. I have gravely doubted the wisdom of some of the more recent measures passed by the national government.

I do not believe the time will ever come again when the railways will not be subjected to comprehensive regulation; but I do think that Dr. Hadley, in the article mentioned, outlined means for bringing about more satisfactory relations between the large corporations and the public that have much more promise than 


\section{PREFACE}

great additional extensions of government regulation. 1 refer to the following sentences in the article:

But I cannot shut my eyes to the fact that these things are what business men must expect, unless business ethics is somewhat modified to meet existing conditions. Industrial corporations grew up into power because they met the needs of the past. To stay in power they must meet the needs of the present, and arrange their ethics accordingly. If they can do it by their own voluntary development of the sense of trusteeship, that is the simplest and best solution. But if not, one of two things will happen: vastly increased legal regulation or state ownership of monopolies. Those who fear the effects of increased government activity must prove by their acceptance of ethical duties to the public that they are not blind devotees of an industrial past which has ceased to exist, but are preparing to accept the heavier burdens and obligations which the industrial present carries with it.

Dr. Hadley's last sentence contains words of wisdom which every important corporation stockholder and officer, and especially every important railway stockholder and officer, could profitably heed. There is much more to be hoped from an enlightened public sentiment which will insist on corporation officers doing their duty to their stockholders and the public, and from corporation officers who will recognize the fact that they are in a very real sense trustees for the public as well as for their stockholders, and who will act accordingly, than from regulation which shall make public authorities practically the managers of lumerties whose ownership continues to be private. There are wide differences of opinion as to whether state socialism is desirable; but there can hardly be 


\section{PREFACE}

any difference of opinion among intelligent men regarding the proposition that public management of properties which are privately owned would lead to intolerable conditions, simply because it would be impossible for either the owners of the properties or the public to bring anybody to an accountability for the results of their management or mismanagement.

Most of the matter in the chapters on "Railways and Waterways"' is from an article by the author which was published in Scribner's Magazine, in June, 1910, entitled "The Proposed Development of Inland Waterways." Parts of an article by the author entitled "Fair Regulation of Railways," published in the North American Review for April, 1910, have been used in the chapters on "Government Regulation." My thanks are due to the editors of these publications for their kind permissions to make use of this material here.

S. O. D.

Chicago, December 15, 1911. 



\section{CON'TEN'TS}

Chapter

PAGE

I. - Principles of Railway RATEMAKing: CoNT of THE SERVICE . . . . . . . . . 1

II.-Principles of Railway Ratemaking: Value OF THE SERVICE . . . . . . . . . 19

III.-Discrimination Between Commodities AND Communities . . . . . . . . . . . 42

IV.-Discrimination BetweEN Shippers - RemeDIES FOR DISCIRIMINATION . . . . 62

V.-Railway Valuation and Profits . . . . 81 VI.-Railway Valuation and Profits (Continued) . 111 VII.-RAILWAY EFFICIENCY FROM THE STANDPOIN'T OF ECONOMY . . . . . . . . . . 124

VIII.-RAILWAY EFFICIENCY FROM THE STANDPOINT OF Public Service . . . . . . . . . 153

IX. - RAILWAYS AND INLAND WATERWAYS: COSTS OF RaIL AND Water Transportation • • 178

X.-Inland Waterways as Regulators of RaILWAY RATES . . . . . . . . . 206

XI.-Government Regulation: Who Shall ReguLATE? • • • • . . . . . . 222

XII.-Government Regulation: Underlying PrinCIPLES . . . . . . . . . . . 246 $\operatorname{INDEX} \quad . \quad . \quad . \quad . \quad . \quad . \quad . \quad 281$ 



\section{THE AMERICAN TRANSPORTATION QUESTION}

\section{CHAPTER I}

\section{PRINCIPLES OF RATEMAKING: COST OF THE SERVICE}

THE part of the transportation business which has received the most public discussion and regulation is railway rates. The complex rate structure, and especially the freight-rate structure, seems to the average man "confusion worse confounded." Even the expert who thoroughly understands the conditions and causes that have produced the rates in one section is apt to be graveled if he tries to analyze and explain those in another section. Civilized man has inherited from his primitive progenitors a strong tendency to suspect and fear whatever affects his welfare which he cannot understand. The average man, not being a railway expert, is apt to attribute the complexities, and seeming or real inconsistencies and injustices, in rates to the railway traffic manager's incompetency, caprice or unfairness. He cannot discern any well-founded principles on 
which the traffic man has acted; and he thinks the worst suspicions engendered by inspection and experience of the rates confirmed when high railway officers go on the witness stand before the Interstate Commerce Commission or the courts, as they sometimes have, and say that rates are made by "instinct" or "intuition"- -that they "just happen so." 1

While many rates, like Topsy, have "just growed," you will find if you study the history of

1 The following, from a paper by the author entitled "Basic Principles of Rates," which was published by the La Salle Extension University and used by it in its interstate commerce course, conveys, I think, the idea that railway men have in mind when they say that they fix rates by "instinct," or "intuition":

"A short time ago, when the traffic manager of a large railway was testifying in a proceeding before the railway commission of a Southern state, the lawyer who was crossexamining him asked him how he knew what was the correct rate to make on a certain commodity between two given points. The traffic manager said he 'guessed' at it. For this statement he was ridiculed by the newspapers. It was said that if railway traffic managers just 'guessed' what rates ought to be, there surely could be no harm in giving the ratemaking power to railway commissions, as they probably could 'guess' as well as the traffic manager. But let us see if the ridicule and the inference from the traffic manager's statement were justifiable.

"If any of my readers have lived on farms where cattle are fattened for market, they know that there are cattle buyers who will go into a pasture and buy a carload of fat steers 'by guess.' That is, they will judge by looking them over what they will weigh, and will purchase them without 


\section{COST OF THE SERVICE}

railway rate development, that, like other economic and social phenomena, it has taken place along well-defined lines and according to pretty clearly discernible principles. The historical method of investigation often explains what it cannot justify. Sometimes it explains and justifies what at first seemed neither explicable nor justifiable.

The railway is the offspring of the turnpike company and of the common carrier by wagon and stage-coach. It has features and characteristics

driving them over the scales. So skillful are they in estimating the weight of a steer that they seldom lose any money by buying this way, while it would be very risky for most people to estimate values in this manner.

"Now, why is this so? It is because the cattle buyer is an expert at this sort of thing. He knows what weight and quality of meat are indicated by a given depth and length of neck and body, size of bone, breadth of back, and general conformation, because he has seen thousands of steer's of all kinds weighed. When he looks over a bunch of steers he seems to know intuitively how much he can afford to pay. But, as a matter of fact, his 'guessing' is perhaps an unconscious application to each steer of general principles derived from observation and experience.

"Now, the difference between the 'guessing' of an expert and a tyro about the value of a steer is similar to the difference between the 'guessing' of an expert and a tyro about what a given freight rate ought to be. The traffic manager's 'guessing' is the exercise of judgment, developed to a degree approaching perfection, by long experience, and guided by knowledge of the fundamental principles of ratemaking and intimate acquaintance with the special transportation and commercial conditions under which his road operates." 
of both its parents. The turnpike company furnished a highway, but no carriage. The carriers by wagon and stage-coach furnished carriage, but no highway. The turnpike company exacted tolls for passage. The carrier's by wagon and stagecoach made charges for carriage. The railway furnishes both a highway and carriage, and charges both for the passage and for the carriage of goods and passengers. The turnpike company charged more for the passage of vehicles of luxury and pleasure than for carts and wagons, because the owners of the former could afford to pay more; it based the rates for the privilege of passage on its value. The early canal companies, which, like the turnpike companies, furnished no carriage, but merely highways, based their tolls on the value of the goods; while the owners of the boats based their charges on movement expenses.

From the first the railway was faced by both the carrier's problem of getting revenue somewhat in excess of movement expenses, and the turnpike and canal companies' problem of getting enough to pay a return on a large and irreducible

'Said Adam Smith ("Wealth of Nations," Book V, p. 326, McCulloch's Ed.) : "When the toll upon carriages, postchaises, etc., is made somewhat higher in proportion to their weight than upon carriages of necessary use, such as carts and wagons, etc., the indolence and vanity of the rich are made to contribute in a very easy manner to the relief of the poor by rendering cheaper the transportation of heavy goods to all the different parts of the country." 
fixed investment. The early railway solved the problem in a perfectly natural way. It fixed charges for carriage, like those of the carrier by wagon or canal boat, which were based on movement expenses; and also separate tolls for passage, which, like those of the turnpike and canal companies, were based on the values, or the abilities to pay, of the things, or persons, transported. One reason for this was the expectation that carriers other than the owners of the highway would haul passengers and goods on it in their own vehicles. This being found impracticable the toll for passage and the charge for carriage were merged in railway "rates."

While this simplified the tariffs, it did not make it either simpler or less necessary to so adjust rates as to earn a return for a service, part of the expenses of which depended mainly, like that of the carrier by wagon, on the amount of business done, and part of which, like that of the turnpike company, depended hardly at all on the amount of business done. In their anxiety to earn enough to cover both these kinds of expenses, the early railway managers made their rates high. It was doubted if railways would ever be able to compete effectively for cheap and bulky traffic against canal boats; that they would ever be able to compete with coastwise vessels seemed most improbable. The directors of the Pennsylvania Railroad did not think coal traffic worth seeking 
loranse it could not he grot for more than 2 cents Mel ton per mile! Il is said a director of the Iondon and Birmingham, when it was suggested (1) him that his aristocratic line carry coal to lonclon in competition with the Grand Junction Canal and the Newrastle coal brigs, exclaimed: "Coal! Why, they will be asking us to carry dung next!"”2

But soon an important discovery in railway economies was made; just who was its Columbus I do not know. This discovery was, that on a road not being worked to its full capacity, traffic need not, to be worth taking, yield enough to cover both its movement expenses and a proportionate share for fixed charges. The fixed charges of a railway, like the fixed charges of a turnpike company, had to be paid whether the traffic was small or great. Therefore, if the revenue from traffic which could not be got except at a low rate would pay the movement expenses its transportation added to previous movement expenses and, besides, contribute anything, however little, to fixed charges, it was desirable.

Suppose a road was hauling 225,000 tons at 2 cents per ton, it oross earnings therefrom being $\$ 4,500$; and that it: operating expenses were

'The Pennsylvania's average freight rate per ton per mile in 1910 was 5.83 mills.

"Acworth's "Elements of Railway Economics," page 63. 
$\$ 2,500$ and its fixed charges, $\$ 2,500$. It had a deficit, then, of $\$ 500$. I have made the figures small for the sake of simplicity; the reader may add as many ciphers as he likes. Suppose there were 145,000 tons of traffic it could get at a rate of not more than $1 \frac{1}{2}$ cents per ton, and that the average movement expenses per ton for handling it would be the same as for handling the traffic it already had. Was the traffic worth taking? It was. The movement expenses of hauling it would be at the rate of 1.11 cents per ton, or $\$ 1,609.50$; the gross earnings from it would be 1.5 cents per ton, or $\$ 2,175$, leaving $\$ 565.50$ net, or $\$ 65.50$ more than enough to cure the deficit. Every ton of the traffic which the road was handling before earned over the movement expenses an average of 8.9 mills for fixed charges. The new traffic earned less than half as much per ton over movement expenses for fixed charges, or but 3.9 mills. But while it did not contribute as much per ton to the total expenses of the business, including fixed charges, the taking or not taking of it was the difference between bankruptcy and solvency.

On a railway which is not working to its full capacity and on which unit costs of labor, materials and interest are stationary, the law of increasing returns operates with even more force than is indicated by this illustration. Not only do not fixed charges increase as the traffic increases, but neither, in these circumstances, do mainte- 
nance or operating expenses. It costs a good deal less than twice as much to haul a car full as to haul it half full; it costs a good deal less than twice as much to run an engine fully loaded as to run it half loaded; it costs a good deal less than twice as much to maintain a track which is being operated to its full capacity than one which is being operated to only half its capacity.

These principles were rapidly and successfully applied, especially in the United States, in the reduction of rates on, ${ }^{1}$ and the development of, three kinds of traffic:

1. Traffic in cheap and bulky commodities, which, because of their low value, could not bear high rates.

2. Traffic moving long distances. The charges of the carriers by wagon, and the tolls of the turnpike and canal companies, had increased rapidly as distance increased. It was not possible for the railway to make all of its rates this way. The carrier by wagon hauled the goods only a short distance. The turnpike company gave passage but for a short distance. Railways rapidly grew to great lengths, and wanted to haul goods for

'These statements and the subsequent discussion relate almost exclusively to freight rates and tariffs. Passenger rates are usually much simpler than freight rates, being commonly based mainly on distance. The traffic is of such nearly uniform charactel that the difficulties and complexities of adjusting rates for handling it are much smaller. 
long distances. But rates which increased as distance increased were incompatible with long hauls, especially of cheap and bulky commodities. Coal might easily move twenty miles for a rate of 2 cents per ton per mile. But 2 cents per ton per mile for 500 miles would be $\$ 10$ a ton.

3. Competitive traffic, whether the competitors for it were canal boats, coastwise steamers or other railways. The railway could not get on any traffic more than the lowest rate which had been fixed by a competing carrier, due allowance being made for differences in service. In many cases railways made lower rates for longer hauls to points where they met competition than for shorter hauls to points where they did not meet it. They made relatively low rates for cheap commodities and long distances because the traffic could not bear higher rates. They made these low rates for competitive traffic because, owing to its ability to move by some other route or routes, it would not bear higher rates.

This has been described as the system of charging "what the traffic will bear." Dr. Hadley" amended the description to "Charging what the traffic will bear, and not charging what it will not bear." But this fixes merely the maximum limit of rates; what the railway can bear fixes the mini-

1"Railroad Transportation-Its History and Laws," by A. T. Hadley. 
mum. "What the traffic will bear"' is measured by the value of the service rendered to the shipper: he will not pay more for it than it is worth to him. What the railioad can bear is measured by whether a rate will increase gross earnings more than the transportation of the commodity to which it is proposed to apply it will increase operating expenses; it cannot afford to take any business for any rate that will not do this. Between these superior and inferior limits - the value of the service to the shipper, and the minimum, or additional,

${ }^{1}$ It is often said that railways charge all that the traffic can bear. Railway managers denounce this as a misstatement of the principle on which they have acted. E. P. Ripley was for many year's a distinguished traffic officer before he became President of the Atchison, Topeka \& Santa Fe, and, both because of this experience and of his great ability to think and speak clearly, an expression from him is entitled to much weight. In testifying before the Interstate Commerce Commission at Chicago in September, 1910, in cases involving the reasonableness of advances in freight rate which the railways proposed to make, Mr. Ripley said:

"First and foremost there never was any better definition of a reasonable rate than that which was given many year's ago by somebody and which has been used as a byword and a reproach ever since, namely, "what the traffic will bear.' That is the best definition which was ever given of it. That does not mean all the traffic will bear; it does not mean all that can be extorted or squeezed out of it, but what the traffic will bear, having regard to the freest possible movement of commodities, the least possible burden on the producer and on the consumer. The middleman can take care of himself. But with these two qualifications, a reasonable rate is what the traffic will bear." 
cost of the service to the railway - all rates have been, or ought to have been, fixed. The object of the railway manager has been to get the maximum net return from the total business. In pursuance of this object he has tried to fix each rate at that point between these maximum and minimum limits where, under the special conditions of the case, he would get the particular volume of traffic which would yield the largest return over the operating expenses which the handling of the particular traffic added to other operating expenses. This often has involved making rates per ton per mile much higher on valuable than on cheap and bulky commodities, on non-competitive than on competitive traffic, and for short hauls than for long hauls; and it usually also has involved making the rates substantially less than the maximum value of the service to the shipper and substantially more than the minimum additional cost of the service to the railway.

The foregoing gives some idea, however inadequate, of the way in which, and the principles according to which, the complicated rate structure, and especially the complicated freight-rate structure, of the United States has been developed. Railway rates in other countries have been developed along much the same lines and according to much the same principles. The main difference has been that in many foreign countries more consideration has been given to the cost of the ser- 
vice ats compared with the value of the service-in other words, to the average cost of the service as distinguished from the additional cost; and to this the greater density of freight traffic that has been developed here, and the lower average rate at which it is handled, are largely due. ${ }^{1}$

There have been innumerable criticisms of the way American railway rates have been made. Some of these have gone merely to the way the underlying principles have been applied-or misapplied; others to the principles themselves. I shall discuss the specific subject of railway discrimination in later chapters. Such discussion should logically be preceded by consideration of what are the standards by which the fairness of rates ought to be measured. This is my task in the present and the next chapters.

One class of persons-including most railway managers, a great many economists and some regulating authorities - think that rates should be based mainly, or even almost wholly, on the value of the service. Another class-including a very few railway men, some economists, probably a majority of railway regulating authorities, and

'The density of freight traffic - tons hauled one mile per mile of line-on the French railways (1907) is 496,939; on the German railways (1908), 827,390 ; and on the railways of the United States (1910), 1.085,745. The average rates per ton per mile are: France (1907), 12.8 mills; Germany (1908), 12.7 mills; United States (1910), 7.53 mills. 
most of the general public--think that rates should be based mainly, or even almost wholly, on the cost of the service.

Many railway men in their public utterances say that rates cannot and ought not to be based to any considerable degree on cost of service. Their practice refutes their theory. Transportation costs are of two kinds-terminal and road haulage. The former are the same per ton whether a shipment moves one mile or a thousand miles. The latter increases with distance. Now, every railway has at the foundation of its rate structure a distance tariff, the rates in which are very high per ton per mile for short hauls, and rapidly diminish per ton per mile as the length of the haul increases. Unless competition interferes, rates always increase in absolute amount with, although not in proportion to, distance, until they reach a point where they can be made no higher without obstructing the movement of traffic. Why are rates constructed thus? Obviously, one reason why they usually are made higher per ton per mile for short than for long distances is that it is believed the short distance as well as the long distance traffic should pay its own terminal expenses; and they usually increase in absolute amount with distance because ordinarily the farther a shipment moves the more its haulage costs.

Again, higher rates per ton per mile are ordinarily charged on local than on through traffic be- 
cause, as local traffic moves in smaller car loads and the trains transporting it make frequent stops, it costs more in proportion to haul it. Higher rates are charged for freight in less-than-car lots because, owing to the larger station and accounting expenses that must be incurred for the lessthan-car lot freight, and to the fact that it moves in smaller quantities per car, its transportation costs more. If costs cut no figure in railway rates, they would be like postal charges, the same for all distances.

Cost largely influences the fixing of rates, not only on the same article when hauled under different conditions, and different distances, but on different articles. There are three important classifications of freight on the railways of the United States: the Official, in the territory east of the Mississippi River and north of the Ohio and the Potomac; the Southern, in the territory east of the Mississippi River and south of the Ohio and the Potomac; and the Western, in the rest of the country. These classifications group commodities, according to their varying characteristics and the varying conditions under which they are transported, into from 6 to 10 classes. The sime rate applies for any given distance on all the articles in a class, but the rate is different for each class. The first-class rate between Chicago and New York, for example. is 75 cents: the sixth-class rate, 25 cents, or 66 per cent. less. Now, of two 
articles having the same value per ton, that which has the greater ratio of bulk to. weight will, other things being equal, be put in the higher class. Likewise, of two articles having similar values and bulks per ton, but one of which is more risky to handle than the other, that which is the more risky to handle will, other things being equal, be required to pay a higher rate.

Furthermore, when the railways go into court to defend rates made by their officers or to attack those prescribed by legislatures or commissions, they very generally base their defense or attack on the ground that the rates made by their own officers are not too high in proportion to the cost of the service, or that those prescribed by the regulating authorities are too low in proportion to it. Where entire schedules of rates are involved, they include in their estimates of cost both operating expenses and fixed charges and what they consider reasonable dividends.

The truth of the matter is, that when the railway man asserts cost of service should not be a factor in ratemaking, he does not mean it. The seeming inconsistency may be due to the fact that his business has been to so adjust rates as to move the traffic, not to analyze and theorize about the principles on which he acts, and that consequently, like most practical business men, when he tries to state the principles by which he has been, and thinks he should be, guided he is apt not to make 
himself clear. What he really means, I think, is merely that the average lolal cost of service, which is what is generally meant by "cost of service," cannot and should not be used as a basis for making rates. For the words "cost of service" do not always mean the same thing to him and others, or even to him at different times. If he is considering what is the very lowest rate he can afford to make, he thinks only of the additional expense that handling the additional traffic will cause. The additional cost of handling certain traffic may be but four mills per ton per mile; if the traffic manager can get it with a rate of five mills, and no more, it is worth having at that rate. But if the road's average cost of handling all traffic is eight mills, obviously he could not take all traffic for five mills. Since he must get an average of eight mills, he makes all traffic that cannot pay that much pay as near it as it reasonably can, and then offsets the traffic which cannot pay the average cost with traffic that is required to pay more than the average cost.

The charge is often made, and with good reason, that in many instances the railways have not given due weight to cost of service. In some instances they have made rates which did not cover even the additional cost. This involves positive loss which has to be made good by making some rates needlessly high. In other cases they have made rates lower in proportion to cost than was 16 
necessary to avoid interfering with the movement and growth of the traffic. This is contrary to sound principles. Every species of traffic should contribute to the total cost of operation as nearly in proportion to the expenses incurred in handling it as it reasonably can. On no defensible principle can part of the traffic be charged more than its proportionate share, and other traffic less than its proportionate share, unless it is not reasonably practicable for the latter to pay its full proportionate share.

One of the main obstacles to the better apportionment of rates according to costs has been the failure of the railways to develop as good methods of cost accounting as are in use in many manufacturing concerns. Some railway men say that the element of joint cost in their business is so large that accurate cost accounting is impracticable. In every system of cost accounting it is necessary to allocate fixed charges and many other expenses on more or less arbitrary bases, but this does not keep them from being approximately accurate, and useful as guides in fixing prices. In the opinion of some who have given great attention to the matter it would be practicable to work out pretty accurate and useful railway cost accounting systems. ${ }^{1}$ The railways introduce very elaborate cost

${ }^{1}$ See the very able opinion of the Railroad Commission of Wisconsin in the passenger rate cases decided in 1907; particularly, Buell vs. C. M. \& St. P. Ry. 
figures in rate cases; and it is a stigma on railway management that the bases on which the calculations have been made sometimes have been changed from case to case, from state to state, and as applied to state and interstate business, so as to have shown that some prosperous railways are losing money on every single branch of their business! When figures prove that the sum of all the parts is less than the whole there is something wrong with them. If railways can work out cost figures to defend or attack rates they can work them out as more or less useful guides for making rates. If the operating expenses of handling each kind of traffic were more carefully calculated, some rates that are now made would not be made, and some would be raised, and others reduced. 


\section{CHAPTER II}

PRINCIPLES OF RATEMAKING: VALUE OF THE SERVICE

MANY persons go so far as to contend that railway rates ought to have been based mainly, or entirely, on cost of service, and that the existing rate structure ought to be so revolutionized as to put them mainly or wholly on that basis. It is said that this is the way prices are fixed in other businesses, and that it is the only fair way to fix either prices for goods or charges for services. This is carrying the cost of service theory much too far. It is not true, as is commonly assumed, that the method of making railway rates according to value given as well as cost incurred is an anomaly in industrial price making. Even if it were that would not be reason enough for trying to revolutionize it.

The manufacturer who makes, or the merchant who sells, but one thing usually tries to base his price on cost. But even he often sells at the same price in different sections of the country, where, to the extent of differences in freight rates, his costs are different; and he often makes different prices to different customers where costs are not 
different. The manufacturer or merchant who makes or sells numerous things having widely varying values, and in whose business, therefore, as in the railway business, there is a large element of joint cost, fixes his prices with as little regard to cost as the railway does its rates.

Take, for example, the case of the meat packer. He pays, perhaps, $\$ 8$ per 100 pounds for a steer. He makes a number of things from the carcasssteaks, roasts, etc., and, finally, from the residue, fertilizer. He does not sell 100 pounds of each for the average cost per 100 pounds of the steer, plus proportionate parts of the expense of operating his factory and his overhead charges. He sells porterhouse steaks for a great deal more than this; he sells fertilizer for very much less. He bases his price for each on its market value. He does not try to base his prices on his average costs, because if he did the prices of his higher class products would not equal, and the prices of his lower grade products would exceed, their value to his patrons, and his profits would be reduced both because he accepted less for porterhouse steaks than they were worth and because he tried to get more for fertilizer than any one would pay.

The analogy with railway ratemaking is perfect. The stone and sand traffic is the railway's fertilizer; the dry goods and other high class traffic is its porterhouse steaks. The packer keeps cost accounts; but they are not his only or principal guide 


\section{VALUE OF THE SERVICE}

in making prices. He consults them to see if the prices of the articles he sells at less than average cost cover the additional cost of making them. If they do, and the prices he gets are the highest he can reasonably obtain without injuring his market, and he receives a substantial profit on all his business, he is satisfied.

But, it is said, the railway, being a public utility, has no right to ignore cost and base its charges on value to the same extent as industrial concerns. As a matter of fact, almost every pub. lic utility to a very great degree bases its rates on the value of its services, and regulating commissions. with public approval, permit, and sometimes require, this. The Pullman company formerly charged the same rate for an upper as for a lower sleeping-car berth. The Interstate Commerce Commission ordered it to make its rates for upper berths less than for lower berths. The public approved, and the Pullman company is complying. Now, it costs more to build the upper berth; in the day time the upper berth passenger has one of the seats which at night are used to make the lower berth; and it is more work for the porter to make up the upper. Therefore, to require a lower rate for the upper berth is contrary to the cost of service theory. It is justifiable only because the lower berth service is the more valuable.

Again, the telegraph companies charge 75 cents for sending 50 words in the form of a day letter 
from Chicago to New York; at night, in the form of a night letter, they send 50 words for 50 cents; and their day press rates are double their night press rates. These differences entirely disregard cost of service, for the companies' fixed charges at night are the same as in the daytime, and their operating expenses per word are no less, and probably greater. The lower rates are based on value of service, and are made to stimulate business when the wires are not busy.

Electric light and power companies make lower rates for power in some hours than in others to get an equal distribution of the load on their plants. The Northwestern Elevated Railroad, under city ordinances, charges me 5 cents for hauling me seven miles between my home and office in Chicago. It charges the man who rides only between Chicago Avenue and the Loop, a distance of only a little over a mile, the same rate. The postal department, the most public of all public utilities, charges the same rate for carrying letters, newspapers and merchandise from your house to a house in the next street as for carrying them from New York to San Francisco; and many favor the establishment of a parcels post, like those of foreign countries, which would carry an eleven-pound package from ocean to ocean as cheaply as for a city block. Obviously these rates are not based on cost.

To say prices or rates are based on "what the 22 


\section{VALUE OF THE SERVICE}

traffic will bear," or on the value of services or of goods, is just one way of saying they are adjusted to supply and demand. The packer charges a lower price for fertilizer than for porterhouse steaks; the telegraph company, a lower rate for night than for day messages; the railway, lower rates per ton per mile on cheap, competitive, or short-haul traffic than on valuable, non-competitive, or long-haul traffic, to stimulate and enlarge the market for the less valuable commodities and services. They are, if you please, by-products, the market's appetite for which has to be whetted and coaxed by low prices.

Even if the system of basing prices and charges largely on the value of commodities or services were not used elsewhere, its use in the railway business would be necessary and justifiable as a matter of public, as well as of railway, policy. While railway rates should be made with constant reference to cost of service, it always has been, and would now be, utterly impracticable to base them solely, or perhaps even mainly on cost. While it is possible to make estimates of the costs of transporting different articles under different conditions these estimates are, and must be, at the best only rough approximations. When they are made they vary extremely and with utter want of relation to commercial conditions, even for different parts of the same railway. Albert Fink, a railway economist of the greatest authority, when 
he was connected with the Louisville \& Nashville Railroad, found that "under the ordinary circumstances under which transportation service is generally performed the cost per ton per mile in some instances may not exceed $\frac{1}{7}$ of a cent, and in others will be as high as 73 cents per ton per mile on the same road." 1 Would even the most Quixotic theorist attempt to base rates on costs varying thus? Costs per ton per mile vary widely on the same railway from month to month, from week to week, and even from day to day, because of variations in the amounts of operating expenses and of traffic. Costs of transportation vary extremely on competing railways, on which the rates must be the same. It is, therefore, not merely desirable, but a matter of absolute necessity, that in ratemaking the cost of the service principle should be supplemented by, and very often completely subordinated to, the value of the service principle. The latter's employment is requisite not only to the development of a large traffic, but to that free circulation of all goods and that development of all the country's natural resources, which are essential to the "greatest good of the greatest number."

As I have said, the three kinds of traffic on which rates are made less than the average-on the basis of additional rather than average cost-

'Report of the Louisville \& Nashville Railroad for 1874. 
are low grade traffic, long distance traffic and competitive traffic.

That the rates on different commodities of widely different values should not be based either on the average or on the actual costs of the service is conceded by practically all who have studied the subject, even those who contend that the cost of service principle ought usually to prevail. ${ }^{1}$ A ton of coal is worth at the mine, perhaps, $\$ 1.50$. A ton of shoes is worth at the factory, perhaps, $\$ 1,500$. Coal moves in carloads of 40 tons or more; therefore, a carload is worth about $\$ 60$. Shoes move in carloads of perhaps 10 tons; therefore a carload is worth about $\$ 15,000$. There would not be much difference between the direct costs of hauling the carload of coal and the carload of shoes. But does it not appeal to equity and common sense that the carload of coal, which is worth $\$ 60$, should be given a lower rate per ton per mile, or even per car per mile, than the carload of shoes, which is worth $\$ 15,000$ ?

Many who concede that rates on different commodities should be based on the value of the ser-

${ }^{1}$ See a very able paper advocating cost of service ratemaking which was read by Halford Erickson, a member of the Railroad Commission of Wisconsin, at the twenty-third annual convention of the National Association of Railway Commissioners at Washington, D. C., November 17, 1910 : also Professor W. Z. Ripley's series of articles on "Railway Rate-Making in Practice," in the Railway Age Gazette, May 7 to June 18, 1909. 
vice deny that this principle should be applied to hauls of the same commodity for different distances. But much long-distance traffic will not bear as high rates per ton per mile as short distance traffic, regardless of terminal expenses. The distance tariff rate on corn per 100 pounds for 10 to 15 miles in Illinois is 3.9 cents. The terminal expenses at origin and destination together are, perhaps, $\$ 6$ a car, or, say, 1.06 cents per 100 pounds, leaving for a haul of 15 miles 2.84 cents per 100 pounds as the strictly transportation charge, or 1.9 mills per 100 pounds per mile. That seems small; but if you applied it on a 500 mile shipment it would be 95 cents per 100 pounds, allowing for no terminal expenses at all.

Much higher rates than any ever charged could be imposed on the more valuable commodities without impeding their movement for even the longest distances, unless competitive conditions intervened. The rate on a pair of shoes from New York to Chicago is about $1 \frac{1}{2}$ eents. If the rate were raised 200, or even 500 per eent., as many shoes would be shipped as before. But in practice it is found that for each of a great majority of commodities there is some rate which is the very maximum that, regardless of distance, it can pay and move. Says Professor W. Z. Ripley:'

1.Railway Rate-Making in Practice," R'tilualy Age Gnzette, May $7,1909$. 


\section{VALUE OF THE SERVICE}

In other words, suppose the traffic consists of grain or coal. No more than a certain amount could ever be charged, no matter how great the distance, without so diminishing the profit in the transaction as to render the business impossible. . . . This maximum varies, of course, with each commodity; on cotton it may be 55 cents per 100 pounds, on grain or coal it will be much lower, and on cement or sand lower still. The problem of the traffic manager is to attain this highest rate as speedily as possible with increasing distance, and to grade his rates with distance up to this level as quickly as possible, consistent of course with maintenance of full volume of business.

Although the traffic, after it has attained this maximum rate, which is the measure of the maximum value of the service of transporting it, will bear no more, it may be profitable to the railway, on the theory of additional cost, to haul it still greater distances at this same maximum rate. And if the railway can do this, it is desirable from the standpoint of the public that it should do so. As a general principle it is in the interest of the public welfare that rates shall be made lower in proportion for long than for short hauls. Rates which are relatively low for short hauls and high for long hauls tend to give the producers and shippers in each community a monopoly of their business in that community. On the other hand, rates which are relatively high for short distances, and relatively low for long distances, enable producers 
to invade each other's territories; and this stimulates commercial and industrial competition, which, when not carried to the extreme, promotes industrial efficiency and tends to keep down prices. The shipper whose territory is invaded is pretty sure to complain loudly because the rates of his competitor are not based on distance; but he can always offer a dozen reasons-good ones, too!why the rates he uses to invade the territory of his competitor should not be based on distance.

The most severe criticisms of railway ratemaking are directed against partial or complete disregard of cost of service in fixing rates on competitive, as compared with non-competitive traffic. Competition is either transportation or commercial - that is, between either railways or shippers; in many cases it is both; and it often justifies disregard of cost of service. Suppose each of two railways reaching a certain market has a coal mine on it, one of which is 200 miles from the market, and the other only 50 miles. Here we have both transportation and commercial competition. If the rates be based entirely on cost of service, the mine 50 miles distant will have practically a monopoly of the coal market, and the road on which it is situated a monopoly of the transportation of coal. If average cost of transportation be disregarded, and only additional cost be considered, and the rates be so made as to enable the operator of the mine 200 miles distant to reach the market 28 


\section{VALUE OF THE SERVICE}

-in other words, be based on the value of the service-the second railway will get to participate in the coal traffic and derive some profit from it, however small; the second coal-mine owner will be able profitably to develop an otherwise valueless property; and the people situated at the market will be able to buy coal shipped over competing roads and produced by competing coal operators, instead of being obliged to deal with transportation and coal-producing monopolies. Can there be any serious question as to which method of ratemaking better promotes the "greatest good of the greatest number?"

If the two mines were located on the same railway, we should have merely commercial competition-that is, competition between the two mine operators. Would the railway, in that event, be justified in so adjusting its rates according to the value of the service, and to some extent in disregard of cost, as to enable both operators to do business and the people at the market to buy from either or both? If the "greatest good of the greatest number," and not merely the selfish interest of the man who owns the nearer mine, is to be considered, there can be no doubt as to the right answer. ${ }^{1}$

${ }^{1}$ Often competition causes cost to be disregarded to such an extent that lower rates are made for longer than for shorter hauls. Whether or not this is ever justifiable will be discussed later. 
Let me give one of the best possible examples where low rates were made to develop traffic which was at once low grade, long distance and competitive, and the results. Merchandise formerly was hauled to the Pacific Northwest in cars which returned Eastward empty. There was a great deal of timber in the Northwest, but it and its products were not used to load these cars Eastward because they could not bear the rates in effect; and they could not bear the rates because they were low grade traffic, because they met in the Chicago and other Middle Western markets the competition of lumber produced in states farther East, such as Michigan, Minnesota and Wisconsin, and because the haul was very long. Mr. James $J$. Hill reasoned that the actual cost to his road, the Great Northern, of transporting this Northwestern lumber would be, not the then average cost per ton per mile incurred in handling its existing traffic, but that, as the cars had to move Eastward, anyway, it would be the difference between hauling them loaded and hauling them empty; and that if he could get rates, however low, which would more than cover this difference he would gain. The rates were made: an enormous lumber traffic was built up; and the profits of the transcontinental roads were largely increased. As the cost of service theory deals with average, and not with additional cost, on that theory these rates could not have been made; and the traffic could 


\section{VALUE OF THE SERVICE}

not have moved. The cost of service principle, as commonly understood, waits for traffic to become able to bear high rates; the value of the service principle makes for traffic which cannot bear high rates, low rates which it can bear.

What were the effects on the various concerns, persons and communities concerned, of the making of these low rates? The effect on the railways was to increase their profits. The effect on the Northwestern lumber producers was greatly to broaden their markets, and to enable them to so increase their expenditures as to promote the development of the Northwest along all lines. It is sometimes said that the effect of taking some traffic at rates below the average cost of service is to render it necessary to make the rates higher on other traffic than would otherwise be necessary. But whatever margin there was between the additional expenses caused by, and the additional revenue derived from, the lumber traffic was just that much added to the clear profits of the roads; and whatever any certain traffic adds to profits must tend to make it practicable to reduce, not to make it necessary to increase, the burden of rates imposed on other traffic. The effect on lumber consumers was to give them a chance to buy from an increased number of competing producers and to postpone the day when they would have to pay higher prices. The only persons who were hurt by the low rates were the more Eastern producers 
of lumber; and I think it ought to go without argrument that rates ought to be adjusted in the interest of the large body of producers and consumers, and not in the interest of the particular producers who happen to be located nearest the markets.

The making of these low rates had an interesting sequel. The price of Northwestern lumber increased until it averaged more than 100 per cent. higher in 1907 than in 1894, when the low rates on it were made. Meantime the lumber traffic grew so heavy that the empty car movement changed from Eastward to Westward. From being the difference between hauling the cars empty and hauling them loaded, the cost of hauling the lumber became the expense of sending cars empty all the way to the Pacific coast and hauling them back loaded. Both the cost of the service to the railway and the value of the service to the shipper having increased, the railways believed they were justified in raising the rates, and in November, 1907, they did advance them 15 to 20 per cent. The shippers appealed to the Interstate Commerce Commission. The Commission upheld only part of the advances. The United States Circuit Court, to which the railways appealed from the Commission, upheld practically all of them. It seemed to railway men that there was ample justification from the public standpoint both for the making of these low rates on lumber and for raising them 


\section{VALUE OF THE SERVICE}

when they had become disproportionately low as measured not only by the rates charged on other commodities, but also by the cost of the service and the value of the service. ${ }^{1}$

Some able economists and traffic managers believe that it would be better for the public if rates were made to bear a more direct and consistent relation to the values of commodities. A railway rate is not a tax, as some have argued. It is a charge, a price, for a specific service. And yet railway charges, and the principles on which they should be made, resemble, in some ways, taxes, and the principles on which they should be levied. It is an equitable rule of taxation that each person should be required to contribute in proportion to his ability toward the support of the government; and, these persons believe, it is an equitable rule for fixing railway rates that, within reasonable limitations, each shipment or commodity should be required to contribute in proportion to its ability to meeting the cost of maintaining and operating the railway and of paying a return on the investment in it. This would mean, in a general way, that if $\$ 1$ was charged for hauling a ton of a commodity that was worth $\$ 20$ a ton, then, other things being equal, $\$ 10$ should be charged for

${ }^{1}$ The next five paragraphs are from the paper by the author entitled "Basic Principles of Rates," already referred to, which is used by the La Salle Extension University in its course on interstate commerce. 
hauling an equal distance, under similar conditions, a ton of a commodity that was worth $\$ 200$ a ton. In each case the rate would be 5 per cent. of the value of the commodity. If a cheap commodity can pay a rate that is 5 per cent. of its value, it would seem that a more valuable commodity could equally afford to pay a rate that is 5 per cent. of its value. Now, the railway traffic managers, in applying the principles of charging "what the traffic will bear," and not charging what it will not bear, have done something analogous to this. They have made dry goods pay more than coal; boots and shoes more than stone; because dry goods, boots and shoes, owing to their greater value, can afford to pay more.

But the principle has not been carried out consistently. Freight rates are almost uniformly higher in proportion to the value of cheap commodities than in proportion to the value of valuable commodities. The total cost of the transportation of the wool in a $\$ 35$ suit of clothes from the back of a sheep to the back of a man is perhaps 7 or 8 cents, while the domestic rate on a bushel of wheat from Chicago to New York is $11 \frac{1}{2}$ cents. The cost of transportation is 19 of the value of the wheat, and only 500 or $\frac{1}{600}$ of the value of the suit. Now, generally speaking, the so-called "masses" are the largest consumers, proportionately, of cheap, bulky commodities, while the so-called "classes" are the largest consumers, 
proportionately, of the more valuable articles. Consequently, a rate system that applies higher rates, proportionately, to cheap than to expensive articles, tends to place a greater burden, proportionately, on the poor than on the more prosperous. Regardless of whether present freight rates are, on the average, too high or too low, it would seem that, for social reasons the railways should be encouraged to make their rates higher on the more valuable than on the cheaper commodities, on the same principle that in taxation we tax luxuries higher than we tax necessaries.

The more one studies ratemaking the more he is impressed with the fact that, broadly speaking, the railway traffic manager does not arbitrarily make rates, but to a large extent, is merely the agent of transportation, industrial and commercial conditions in adjusting them. The seeming, or real, inconsistencies, anomalies and injustices that we frequently meet in classifications and schedules are mainly due to this cause.

The student of biology knows that in every animal organism there survive numerous atrophied parts which formerly served highly useful purposes, but, which, owing to changes of the environment in which the animal lives and gains its subsistence, have ceased to be of value, or, like the human vermiform appendix, have become even a chronic source of danger. The student of jurisprudence knows that in every branch of his sci- 
ence there survive rules of substantive or adjective law handed down, perhaps, from the period of feudalism, many of which are ill-adapted to modern conditions, and others of which demand excision by the lawmakers. Similarly, the student of railway ratemaking and railway economics often finds rate adjustments that seem ill-adapted to industrial and commercial conditions, or positively unjust; and he may be disposed at first to denounce railway managers for making such rates. But if he will study the adjustment carefully he may find that when it was first made it was admirably adapted, like some of the feudal rules of law which I just mentioned, to the conditions that then existed. He also may find, as students of jurisprudence often do, that the thing he at first condemned is not nearly so ill-adapted to existing conditions as at first he thought. And if he pursues the matter far enough he may find, as many who have set out to reform parts of our jurisprudence have found, that the thing he criticises is so bound up with other things of vital importance and value that it cannot be eradicated without doing a great deal more indirect harm than direct good. This explains why traffic managers often are very slow or reluctant to make changes that to the lay mind seem clearly fair and desirable.

Then, sometimes changing conditions force the traffic managers to abandon old adjustments of rates, just as changing conditions often force the 36 
most conservative courts to abandon old precedents or make new ones. Some years ago the manufacturers of cotton piece goods in New England appealed to the railways in that section to make them lower rates to the West. They pointed out that they had to pay for the transportation of raw cotton the long distance from the South to New England, as well as for the transportation of cotton goods from their mills to the West, while competing manufacturers in the South had only a relatively small rate to pay for the transportation of raw cotton to the mills. The consequence, the Eastern manufacturers said, was that they were gradually becoming unable to meet in Western markets the competition of their Southern rivals.

When the Eastern roads hesitated about making the reductions asked for the New England manufacturers said that unless they were made they would have to move their factories to the South. The Eastern roads then made the desired reductions. Now, you might say that the traffic managers did not have to make the lower rates. But probably they had either to make them or lose a large amount of traffic. And that is the kind of situation that confronts the traffic manager every day. He is seeking to get the largest possible traffic and earnings for his own road. But to do that he has got to adjust his rates just as perfectly as possible to the conditions created by the past and present competition of railways, waterways, 
producing centers and markets. He may charge all the traffic will bear; but he is very careful not to charge more than it will bear; and how much it will bear is always determined by circumstances many of which are entirely beyond the control of any man or set of men.

If my reasoning is not entirely wrong, rates cannot be, or at least ought not to be, based wholly on either the cost of the service to the railway or its value to the shipper. They must be, or at least should be, based on both. They cannot be, or at least should not be, based wholly on the actual or the average cost of the service, because they would obstruct or prevent the movement of a great deal of traffic which, from the social point of view, it is desirable shall move. ${ }^{1}$ They should not be based wholly on the value of the service, because if they were some traffic would be charged less than the additional cost of handling it; and

'We may perhaps assume that the average cost per ton per mile, including all operating expenses, taxes and return on stock and bonds is 7.53 mills, which is the average rate per ton per mile in the United States. Suppose we should abolish all the existing complicated classifications and taritfs and begin to charge a flat rate on all commodities of 7.53 mills per ton per mile. We would then have rates based absolutely on distance and average total cost of service. Millions of tons of ore, coal, stone, etc., are hauled each year for $3 \frac{1}{2}$ to 4 mills per ton per mile. It cannot be assumed that they can bear a higher rate; if they could the carriers would hardly make on them a rate so much below the average. The first effect, therefore, of the application 


\section{VALUE OF THE SERVICE}

some traffic might be charged more than it ought to be required to pay. For example, the rate on a suit of clothes for a thousand miles may be 6 cents. If, instead, the rate were 60 cents it would not exceed the value of the service and the clothes would be shipped. The fact that the rates on the more valuable goods are so small in proportion to their value, and that an advance of 10 , or 100 , or even 1,000 per cent. in them probably would not hinder the movement of the traffic is sometimes used as an argument in favor of higher rates. Within certain limitations, and under certain conditions, it is a valid argument. If, in order that the railways might continue to give good, improving and increasing service it were necessary that the rate on a suit of clothes be even 60 cents and that the rates on other valuable commodities be proportionately high, it would be best for the public to permit the roads to charge them. But no matter how

to all traffic of a rate based on average total cost would be that an enormous amount of this low grade traffic would quit moving. The resulting slump in earnings would necessitate an increase in the rate. This would make it too high for another large quantity of relatively low grade traffic, and there would be another slump in business and earnings which would necessitate another increase in the average rate. The ultimate result, it would seem, would be that the rate would become so high that only the higher classes, or even the highest class, of commodities could move. Much the same effect would be caused by trying to base rates on actual total cost, as distinguished from average total cost. 
small in proportion to the value of goods a rate may be, and how little a raise in it would affect the movement of the traffic, the rate comes out of somebody's pocket, and therefore if the traffic is already paying the average total cost of transportation or more there can be no justification for advancing the rate, unless such advance is needed to enable the railway to earn enough to continue to exist and to give the public good, improving and increasing service.

The foregoing considerations regarding the application of the cost-of-the-service and the valueof-the-service principles suggest two vitally important points. The first is, that there must be discrimination in rates; and it is necessary to determine when in the application of these basic principles fair, and when unfair, discrimination results, and how unfair discrimination may be prevented. The second point relates to the question of what return railways should and must be allowed to have in order that they may give good and adequate service. We know that in the past the application-or misapplication-of these underlying principles has resulted in many unfair discriminations. We know that it is essential, in order to have good and adequate transportation, that the railways be able to earn their operating expenses and such interest and dividends on their bonds and stocks as will make the railroad business attractive to investors; proper interest and divi- 
dends as well as operating expenses and taxes being factors in the entire cost of transportation which must be incurred and met. It is much easier to state the basic principles than it is to determine what is unfair discrimination, and when and where it has taken place and is taking place; or than to determine what is the return that railways should and must be allowed to earn, on what basis it should be computed, and what railways are now earning, and what, if any, are not earning, this desirable and necessary return. I shall take up the question of discrimination in the next chapter, and shall later discuss the questions of railway valuation and financial return. 


\section{CHAPTER III}

\section{DISCRIMINATION BETWEEN COMMODITIES AND COMMUNITIES}

IN the consideration of many subjects differentiation and definition should precede discussion. This is conspicuously true of railroad discrimination. Many persons condemn railroad discrimination as if it were essentially wrong. They overlook the fact that in all thinking and affairs there are at least two kinds of discrimination. In one sense, to discriminate is to "set apart as being different," to "distinguish accurately"; in another, it is to "treat unequally." When we call a man "discriminating" in taste or conduct we do not dispraise, but praise him. Only when we say he discriminates, meaning that he "treats unequally," "do we condemn him. Now, this distinction holds in railway as in other matters. You could no more have satisfactory rates and transportation without the discrimination that "sets apart things which are different" than without it you could have philosophy, or friendships, or statesmanship, or industry, or commerce. Entirely

' See an article by E. P. Ripley in the Atlantic Monthly for January, 1911. 
undiscriminating rates and service would be most unfair and intolerable. The important question, then, as to railway rates and railway services is not whether they discriminate, but whether, when they do, they do so fairly or unfairly-whether they "distinguish accurately" or "treat unequally."

Many consider railway discrimination something fundamentally different from discrimination in other businesses. Merchants and manufacturers "lay the flattering unction to their souls" that it is wrong for the railway to publish a schedule of rates and secretly depart from it for favored shippers, but right for the manufacturer or merchant to publish price lists and depart from them for favored customers. But the difference between railroad discrimination and discrimination in other businesses, it would seem, is mainly legal, not ethical. Understand, I do not say it is morally as right for the railway to discriminate as for the manufacturer; but merely that it is morally as wrong for the manufacturer unfairly to discriminate as for the railway. Under the common law even the legal distinction was not made. Unfair discrimination has nothing to do with the absolute amount of rates; it is an inequitable relation between them. Now, under the common law such a relation was not illegal. All the common law required was that a rate should not be excessive. If it was not, a shipper would not be heard by the 43 
courts to conplain that some one else got a lower rate.

It may be said that the railway's service being legally public imposes a special moral obligation not arbitrarily to discriminate. But if an act is immoral, laws punishing it do not make it more so. Manufacturers enjoying the benefits of a protective tariff are thereby as much obligated morally to deal fairly as are railways exercising the power of eminent domain. A more closely analogous case is that of water-carriers. They use navigable highways owned, developed and maintained by the public. They exercise the power of eminent domain to get land for wharfs, etc. The public has the same legal power to regulate their charges as those of railways, and they owe it as high a duty. Yet we let boat owners, even on our coastwise and inland waterways, where they compete directly with railways, discriminate as they please as to all traffic but that moving partly by water and partly by rail; and they use the privilege to the fullest extent.

Often an economic distinction is drawn between railways and other concerns, based on the idea that competition regulates prices in other industries, while each railway is practically a monopoly where it is the only line, and practically a transportation monopoly exists at other places where community of interest arrangements and consolidations have eliminated active competition. The 
monopolistic nature of the railway does give the government a special right and duty to regulate its charges. But I am unable to see much economic difference between the act or effect of arbitrary discrimination by a railway monopoly and by an industrial monopoly, such as some of the great American "trusts," which have got as complete control of prices as any railway combination ever got of rates.

This parallel between discrimination in the railway and in other fields has not been introduced in defense of unfair railway discrimination. It has been the most pervasive and pernicious abuse that ever developed in the railway business. No efforts should be spared to extirpate it. But there has been, perhaps, too much tendency to single it out as something so peculiarly odious and harmful as to merit peculiar obloquy as well as peculiar punishment. Our aim should be to get all kinds of business on a higher moral plane. We can get the railway business on a higher plane by public regulation and by training and keeping trained on it an intelligent and militant public opinion. About the only effective means we have as yet found for raising other businesses to a higher moral level is the creating and applying to them of a discriminating and exacting public sentiment; and we do less than justice to railway managers and owners, and interpose a formidable obstacle to the reform of other businesses, when we con- 
demn and punish in the railway business, what we permit, condone and even foster, elsewhere.

The distinction between fair and unfair railway discrimination is clearly recognized by the law. The Act to Regulate Commerce ${ }^{1}$ defines unjust discrimination as charging or receiving from one a greater or less compensation for any service than is charged or received from another for a "like or contemporaneous service in the transportation of a like kind of traffic under substantially similar circumstances and conditions." Elsewhere ${ }^{2}$ it is defined as "any undue or unreasonable preference or advantage to any particular person, company, firm, corporation or locality, or any particular description of traffic." When traffic is not "of a like kind," or the circumstances and conditions of transportation are not substantially similar, or no undue or unreasonable preference or advantage is given, discrimination is proper and legal.

But what are "like kinds of traffic"? When are "circumstances and conditions substantially similar"? When is an "undue or unreasonable preference or advantage" given? The standards to be applied are the fundamental principles of correct ratemaking - that is, what it costs the railway to render the services, and what are their relative values. Silk and sand are not a "like kind of traffic," and are not hauled under "substantially

'Section two.

"Section three. 


\section{DISCRIMINATION}

similar circumstances and conditions." As silk is much the more valuable, the value of the service of hauling it is greater; and as it moves in smaller carlots and on faster trains, and there is more risk in handling it, its transportation costs more. The circumstances and conditions of the transportation of goods from New York to Spokane, Washington, an inland city, and to Seattle, which is on an arm of the sea, are not, the Supreme Court of the United States has held, substantially similar. There is cheap water transportation at Seattle. There is not at Spokane. Therefore the value of the railway service to the shipper at Seattle is limited by what he can bring his goods in for by water, while its value to the shipper at Spokane is not thus limited.

Of course, ultimately all discriminations are between shippers or consignees; but for convenience they may be divided into discriminations (1) between commodities, (2) between localities, and (3) between persons.

All classification is discrimination. It is the segregation of things, which, from the special viewpoint of the classifier, are different, and the grouping of things, which, from his viewpoint, are similar. As I have said in another chapter, railway classifications divide commodities into from 6 to 10 groups having different rates. There are also many "commodity rates" which are exceptions to, and lower than, the class rates. 
Some commodities are competitive with each other; most are not. Competition between commodities affects classification and ratemaking because the adjustment of rates may determine whether one commodity shall be substituted for another, or whether one or both shall be produced. In one case before the Interstate Commerce Commission ${ }^{1}$ the question was whether the railways were justified in charging between New York City and Atlanta, Georgia, a rate of 33 cents per 100 pounds on common soap and one of 73 cents on Pearline. It was shown that the two commodities were competitive in that they could be substituted for each other, and that the difference in the costs of transporting them did not alone justify the difference in the rates. It was also shown that Pearline was about twice as valuable as common soap, and that common soap moved by water as far as Savannah, Georgia, while Pearline, owing to its susceptibility to dampness, could not move by water. The Commission held that the disparity between the two rates was too wide, but that "the very great difference in the value, and also the risk in case of serious accident in the transportation of Pearline as compared with common soap, would seem to indicate that there is ground for a reasonable difference in the freight rates on

'Jas. Pyle \& Sons vs. E. Tenn., Va. \& Ga. R.R. Co., 1 I. C. C. Rep., 465. 
these two articles"; and it ordered a rate of 60 cents on Pearline, which was almost double that on soap. The differential was based almost not at all on the difference in the costs of the services, which was small, but almost entirely on the difference in the values of the services, which was large.

Some of the best illustrations of discriminations, both fair and unfair, between commodities are afforded by the rates on raw materials and their products; for example, on wheat and flour, corn and corn-meal, live stock and packing-house products. Both the cost and the value of hauling corn-meal are greater than those of hauling corn. Therefore, the Interstate Commerce Commission in one case ${ }^{1}$ allowed a differential of 3 cents per 100 pounds between the rates on them from the Missouri River to points in Texas, and in another case $^{2}$ one of 5 cents between the rates on them from the Missouri River to the Pacific coast. The competitive relation between grain and its products is such that if the rate on flour, for example, be made higher than that on wheat the tendency will be to concentrate the milling industry near large consuming markets; if the rate on wheat be made the higher the tendency will be to relegate milling to the wheat-growing sections; while if the rates be the same, or substantially the same,

${ }^{1} 11$ I. C. C. Rep., 220.

211 I. C. C. Rep., 212. 
the millers at all points will be put practically on a parity. Competition between the millers and the railways serving them has caused the rates on grain and its products to be usually made the same. The social advantages of having them so adjusted as to put the millers at different points on a substantial parity justify, from the public standpoint, the disregard, to this extent, of the cost and the value of the service. In some cases competition has caused the rates on grain products to be made lower than on grain. It is hard to defend such an adjustment on any ground except that it is the policy of our law to foster extreme railway competition, and that this is one of its results.

Some of the best examples of unjust discrimination between both competitive and non-competitive commodities are to be found in the rates on live stock and packing-house products. The Interstate Commerce Commission once estimated the value per 100 pounds of live hogs at from $\$ 4.50$ to $\$ 4.75$, and of dressed pork at $\$ 7.50$. The values of both are greater now, but the relation is about the same. In one case ${ }^{1}$ the Commission, basing its findings on the testimony of railway experts, held that the cost of hauling packing-house products was the greater. In the same case, on the basis of the same testimony, of the same experts, the

Chicago Live Stock Exchange $2 s$. C. G. W. Ry. Co. et al., 10 I. C. C. Rep., 428. 
courts held that the cost of hauling live stock was the greater. This illustrates the difficulty sometimes met in finding out what is the cost of transportation! The case mentioned grew out of the Chicago Great Western's having reduced the proportional rate on packing-house products from the Missouri River to Chicago from $23 \frac{1}{2}$ to $18 \frac{1}{2}$ cents in consideration of a contract with the packers on the Missouri River, under which it was to be given a stipulated part of their business for seven years. There being no corresponding reduction made in the rate on live stock, this made the packing-house products rate substantially lower than the live stock rate, which tended to cause live stock to be killed at the packing houses on the Missouri River, rather than in Chicago. The Chicago Live Stock Exchange complained that this was an unfair discrimination against the live stock traffic and against the Chicago market. The Interstate Commerce Commission upheld it. "The value of the article is important," said the Commission, "principally because of its bearing upon the value to the shipper of the transportation service; and the value of the service is, and has always been, considered by carriers one of the important elements to be considered when fixing rates to be charged for transportation."

The Supreme Court ${ }^{1}$ overruled the Commission,

${ }^{1}$ I. C. C. vs. C. G. W. Ry. Co. et al., 209 U. S., 106. 
holding that the rates were the direct result of competition between the carriers; that they had not changed the volume of traffic to Chicago; and that therefore an unlawful discrimination was not proved. Not one railway traffic officer or economist in a hundred would dispute that the rate principles stated by the Commission were correct, and that the making of the lower rates on packinghouse products was economically unjustifiable. But so long as it is the policy of our law to compel unrestricted competition between railways, the courts cannot be blamed for straining a point to uphold rates directly resulting from that competition. This low rate on packing-house products was not merely unfairly discriminatory as compared with the rates on live stock. It was unfairly low as compared with practically every other rate of the railways making it. For example, the rate on mixed carloads of dressed poultry and eggs from the Missouri River to Chicago was 45 cents, or 150 per cent. higher. Most of the railways recognized that it was at once so unfairly low as compared with the rates on other commodities, and so unremunerative because of the expensive service given for it, that in 1910 all but two raised it back from 18.1. to $23 \frac{1}{2}$ cents. It is still in effect on these two.

It has been said by the Commission and the courts that where the competitive relation between two commodities, such as flour and silk, is very 
remote they will not disturb a rate on one because it is relatively very high or very low compared with the rate on the other. But the rates on all commodities should be adjusted with reasonable reference to the costs and values of the services of hauling them. If the rate on one is made unreasonably low, measured by these standards, as was and is done in the case of packing-house products, either (1) the carrier does not earn as much from its whole business as it is entitled to, or (2) some traffic is charged disproportionately high rates to offset the disproportionately low rates accepted on other traffic. In the one case, the stockholders of the railway suffer; in the other, the shippers that are charged too much suffer.

The second class of discriminations I have mentioned-those between localities-have been, especially in recent years, the subject of bitter complaints and endless controversies. An analysis of all the species would alone require a good-sized volume; I shall have to confine myself to a very few genera.

Rates in some parts of the country are higher than in others. The people of the sections where they are comparatively high often contrast their rates unfavorably with those of sections where they are comparatively low. The fact that the rates of one section are higher than those of another is not, however, proof, or even prima facie evidence, of unfair discrimination. The railways 
of some sections are built and operated through mountains where the costs of construction, maintenance and operation are high; in other sections they are built and operated across prairies, where construction, maintenance and operation are comparatively inexpensive. These differences in the costs of service justify differences in the rates. Again, the traffic in some sections is much denser than in others. The Interstate Commerce Commission divides the railways of the United States into 10 territorial groups. In group 2, including New York, New Jersey, most of Pennsylvania, and part of Maryland, the railways had, in 1909, a freight density of $2,451,841$ tons hauled one mile per mile of line, and a passenger density of 290 ,023 passengers hauled one mile per mile of line. In group 9, including Louisiana and Texas and a part of New Mexico, the density of traffic was but 411,357 ton miles and 67,097 passenger miles, ${ }^{1}$ or less than one-fifth of what it was in group 2 . Even in group 6, including Illinois, Wisconsin, Iowa and Minnesota, and parts of Missouri, Michigan, South Dakota and North Dakota, the density was less than one-third that of group 2. The less the density of traffic the more it costs to haul each unit of traffic, and the higher the rates properly may and, indeed, must be. Comparisons of rates in different sections mislead unless they take into

"'Statistics of Railways in the United States," 1909. 


\section{DISCRIMINATION}

account these dissimilarities in the "circumstances and conditions" of transportation. If, however, these dissimilarities be allowed for, comparison of the rates of one section with those of others is a good test of their reasonableness.

In other cases communities complain that part of their rates are high compared with the rates on the same commodities in other sections. When the entire schedules of rates of such communities, including those on both inbound and outbound traffic, are scrutinized it may be found that while part of their rates are relatively high, part are relatively low. For example, there has been much complaint that the rates from the East to places between the Rocky and Sierra Nevada Mountains are excessive. But examination of the rates from this section to the East shows they are relatively low. Outbound rates on the products of the country had to be made low per ton per mile to enable them to compete in the Middle Western and Eastern markets with the similar products of more Eastern communities. The rates from the East to these communities were made relatively, and in some cases very, high, because they applied on merchandise which could bear high rates, and because, as the railways had to make low rates on the outbound traffic, they considered themselves justified in sweetening their revenues with high rates inbound. The consumers who ultimately paid the high inbound rates were largely the pro- 
ducers who paid the low outbound rates. Both classes of rates were made in disregard of cost of service; they were based on "what the traffic would bear" ; and if, for this reason, the high inbound rates should be condemned, then, for the same reason, so should the low outbound rates be. But without the low rates out, production in that section would not have been so well fostered; and without the relatively high rates in the railways could not have lived while production was being fostered. Before we decide any community is being unfairly treated we should always compare not merely part of its rates with part of those of other communities, but all of its rates with all of those of other communities.

I have tried already to show that rates ought not to be, and, indeed, cannot be, based entirely or mainly on distance. Ordinarily they should increase with distance, but not in proportion to it. Often, however, distance is almost wholly ignored. For example, the rate on oranges was $\$ 1.15$ per 100 pounds from California to Salt Lake City and the same from California to all points farther East, including New York City. The people of Salt Lake City complained" about this arrangement. It does look unfair on its face. But there is a reason, good or bad, for all things, including

Commercial Club of the Traffic Bureau of Salt Lake ('ity, Utah, es. A. T. \& S. F. Ry. Co. th al. 
all railway rates. The farther East the oranges are hauled the greater is the cost of service. But, also, the farther East they go the stronger is the competition that they meet from the oranges of Florida and the West Indies. Therefore, the rates to the East had to be made on the basis of additional cost, or value of service, rather than on that of average cost, because otherwise the California producer could not sell his oranges in the East; the railway would not get to haul them there, and the Eastern consumer would not get to consume them. The fact that the highest rate the railway could secure to the most distant markets was relatively low made it necessary, if it was to receive a reasonable profit from its total orange business, to grade its rates up to this maximum as quickly as possible. Whether this way of making rates is justifiable, I leave to the reader's judgment; but it is worth remarking in passing that while the people of Salt Lake City complained that their rate should not be as high as that to Chicago and New York, the people at Chicago, 1,400 miles farther East, and at New York, 2,400 miles farther east, have never been heard to complain that their rate should not be as low as to Salt Lake!

Most complaints about discriminations between localities come from communities more or less directly competitive. The most strenuous and insistent relate to instances where the rates are not merely lower per ton per mile to some communities 
than to others, but are absolutely less for longer than for shorter hauls. If there be cases where the charging of a lower rate for a longer than for a shorter haul is justifiable it goes without saying that there are conditions under which less extreme discriminations are justifiable. I certainly do not believe that all past or existing instances of the charging of higher rates for shorter hauls can be defended; but I do believe there are circumstances in which this method of making rates is clearly defensible.

Suppose a railway is 100 miles long between two points, $\mathrm{A}$ and $\mathrm{D}$, and that its rate between them is $\$ 1$. Suppose another line to be built over a more circuitous route, so that between the same points it is 125 miles long; and that it charges $\$ 1.10$ to a point, $\mathrm{B}, 110$ miles from $\mathrm{A}$, and $\$ 1.20$ to a point, $C, 120$ miles from $A$, and meets the $\$ 1$ rate of the older road to $D$. All the rates are based absolutely on distance, except the second road's rate from $A$ to $D$. Its manager knows this $\$ 1$ rate will not cover the average cost of handling all the business, but it is all he can get and he figures that it will cover the additional cost of handling the A to D traffic and leave some profit. The first road made this rate originally; it was there before his road came; his road merely met it. If he reduced all intermediate rates to the same basis the people at the intermediate points on his line would have lower rates per ton per mile, or in pro- 
portion to cost, than those on the competing line; and, anyway, he could no more afford to do this than he could afford to reduce his rates on dry goods to the basis of those on coal, or than the packer could afford to reduce his price for porterhouse steak as low as his price for fertilizer.' If he did not meet the competitive rate he would forego whatever profit he might get by participating in the competitive traffic, and the people at non-competitive points on his line would be no better off, because the $\$ 1$ rate from $A$ to $D$ was made by the first road and would be kept in by it in any event. In fact, it would be better for the people at intermediate points on his line for him to meet the competitive rate, for whatever profit he thus got would tend to enable him either to make lower rates to the intermediate points, or to

${ }^{1}$ It is commonly assumed that if railways were absolutely prohibited from making lower rates for longer hauls they would reduce all their intermediate rates. What they would usually do, unless prevented, would be to raise their rates for the longer hauls; for they would usually lose more by reducing their intermediate rates than by ceasing to compete. The only state where a long-and-short haul rule has been rigorously enforced is Iowa, and there the longer lines between any two points commonly do not meet the rates made by the shortest line. N. S. Ketchum, a member of the Iowa Railroad Commission, in a recent newspaper interview, advocated modification of the Iowa law so as to authorize the Commission to determine when rates for shorter hauls might be made higher than for longer hauls, saying the present rigorous law injures the state's industries. 
improve the service of his road. The most powerful stimulus to improvements in service is equality in rates between competitive points; for where rates by competing lines are the same, superiority of service is the only thing a road can offer to attract competitive traffic.

The competing route, instead of being a shorter railway, may be a waterway. A great majority of the instances of the charging of lower rates for longer hauls are due to controlling competition by a shorter road or by a water route at the more distant point.

Suppose, however, there are two competing railways of substantially similar lengths between large markets; and that, owing to their competition the rates to the large centers are reduced below those to intermediate non-competitive points. The discrimination under these conditions is indefensible, for the competition between the railways is a condition created by themselves and one which, unlike substantial differences in their lengths, or water competition, they could remedy. I say it is indefensible, but I say it with one reservation. As it is the policy of our law to compel unrestricted competition, and as this discrimination is a direct result of competition, the railways may with much truth retort on their accusers that they commit the offense under duress from the law and the courts.

Again, railways sometimes make lower rates for 60 


\section{DISCRIMINATION}

longer hauls merely to enable some shippers to meet the competition of other shippers. They have made lower rates on furniture from the Middle West to the Pacific coast than to intermediate points such as Spokane, Washington, not because of water competition, for furniture does not move by water no matter how low a water rate is made; but to enable the Middle Western furniture manufacturer to compete with manufacturers on the Pacific coast, who make furniture from lumber native to that section. When a railway accepts a lower rate for a longer haul to meet the competition of a shorter railway or a water line, it can truly say that it is justified in so doing because it did not make the lower rate originally but that the competing line made it first and that it merely met it. But here the railways themselves made the low rate to the coast originally; and for them thus voluntarily to make the low rate to the coast without making it for shorter distances is regarded even by many railway men as an unfair discrimination against the intermediate points. 


\section{CHAPTER IV}

DISCRIMINATION BETWEEN SHIPPERS -REMEDIES FOR DISCRIMINATION

THE most harmful form of unfair discrimination is the third kind I have mentioned - that between shippers. Our law seemingly allows but one form of freight-rate discrimination between persons, viz., between those shipping in car lots and those shipping in less-than-car lots. This distinction is justified by the facts that the station and accounting expenses of handling less-than-car lot freight are greater, and that the cost of hauling it is greater because usually the amount of it moved per car is smaller. No doubt the cost per car load of handling the goods of those who ship in multiple car load or train load quantities is smaller than that of handling the goods of those who ship in single car loads; but the difference in cost is small, and the value per car load of the service to the small shipper is no greater than to the large shipper. Therefore, there is perhaps little justification for making specially low rates for greaterthan-car load quantities, although special rates for train loads are quite generally granted by the railways of Europe. 


\section{DISCRIMINATION-REMEDIES}

The single discrimination permitted by law is very far from being the only one that has been practiced. Before, and for some years after, the Interstate Commerce Act of 1887, the more or less secret paying of eash rebates was universal. Every shipper for whese business there was any competition got them; the only difference was that some got bigger ones than others. After federal legislation was passed against rebating human ingenuity and cunning were exhausted in contriving means and devices for continuing it without the direct and vulgar solicitation and payment of money. Both railway men and shippers acted on the theory that that which we call a rebate by any other name would smell as sweet. To enumerate in all their versatility and shamelessness the multifarious lawless means used by shippers to get through railway concessions the better of other shippers, and by railways to get by the same means the better of other railways, would be a post-mortem both unfruitful and unedifying. Every one now admits that until 1906, when the Hepburn Act went into effect, all railways unfairly discriminated between shippers, and that all shippers sought and accepted all the good things that were being passed around, each being scrupulous only to seek and struggle for more than his fair share. It will be more to the purpose, rather than to review the bad conditions prior to 1906 , to consider those that have existed since. 
There has been a very great and most salutary reduction of all forms of unfair discrimiration, and especially of unfair discrimination between persons. The improvement has been so extraordinary that those who have been in close touch with railway affairs only since 1906 find it hard to believe what was done before. It is even said sometimes that unjust discriminations between persons ended in 1906. Unfortunately, that is not true. Rebating in the old form of cash deductions from published rates practically ceased; but unjust discrimination between shippers did not cease. Fortunately, it now appears in the published tariffs, where it is easier to detect. I have known people to defend certain existing discriminations because, as they say, they are published and therefore legal. The law prohibits unfair, not merely secret discrimination. Otherwise, it would be easy to anoint with printers' ink the blackest and ugliest discrimination and make it, legally, fair and beautiful.

One existing form of unfair discrimination is the giving of disproportionately low rates on commodities made or handled almost exclusively by certain of the large "trusts." I have mentioned the very low rates from the Missouri River to Chicago on packing-house products. They are typical of not a few rates made for the special benefit of large industrial combinations.

Another good example of unduly low rates made 64 


\section{DISCRIMINATION-REMEDIES}

for the benefit of large shippers is afforded by the rates on copper. The principal shippers of this commodity are such large concerns as the Amalgamated Copper Company and the American Smelting and Refining Company. It is very valuable, the price at present being $12 \frac{1}{2}$ cents per pound, which makes a 60,000 pound car load worth $\$ 7,500$. Spokesmen of the railways always lay great stress on the principle that rates should be based on the value as well as on the cost of the service; they sometimes contend that they should be based almost entirely on its value. The values of the services of hauling different commodities depend mainly on the values of the commodities. Therefore, on the value of the service principle, copper should be charged a relatively high rate. And yet it was shown in the testimony in the Salt Lake rate case that the copper rate from Utah and other parts of the West to Omaha was less than the rate on common junk!

The copper rate from Minnesota Transfer, Minnesota, to New York City is 20 cents per 100 pounds. The distance being 1,324 miles, this figures out the extremely low rate of 3 mills per ton per mile. The revenue from a 60,000 pound car load is but $\$ 120$, and the freight charges are but 1.6 per cent. of the value of the commodity. Compare this rate on copper with those on corn, wheat and flour from Minneapolis to New York City, a distance of 1,333 miles. The price of corn at the 
time this chapter is written is $63 \frac{1}{4}$ cents per bushel. A car load of 60,000 pounds is, therefore, worth $\$ 676.78$. The corn rate is $23 \frac{1}{2}$ cents per 100 pounds, or 3.5 mills per ton mile, which yields a revenue per car load of $\$ 141$. The freight charges are 20.8 per cent. of the value of the shipment. Wheat is worth $86 \frac{3}{4}$ cents per bushel, and therefore the value of a 60,000 pound car load is $\$ 867.50$. The rate on it is 26 cents per 100 pounds, or 3.9 mills per ton mile, which yields a revenue of $\$ 156$ per car load. The freight charges are 17.9 per cent. of the value of the commodity. Flour is worth $\$ 4.90$ per barrel. There being 300 barrels in a car load of 60,000 pounds, its value is $\$ 1,470$. The rate is 25 cents per 100 pounds, or 3.8 mills per ton mile. The revenue per car load is $\$ 150$, which is 10.2 per cent. of the value of the commodity.

The rates on copper, corn and wheat from Omaha to New York are even more significant. The distance is 1,400 miles. The copper rate is 20 cents per 100 pounds, or 2.85 mills per ton mile. This yields a revenue-again using the 60,000 pound car load as a basis - of $\$ 120$ per car; and the freight charges are 1.6 per cent. of the value of the commodity. The rate on corn is 27 cents per 100 pounds, or 3.85 mills per ton mile. This yields a revenue of $\$ 162$ per car, which is 23 per cent. of the value of the commodity. The rate on wheat is 28 cents per 100 pounds, or 4 mills per ton mile. 


\section{DISCRIMINATION—REMEDIES}

This yields a revenue of $\$ 168$ per car, which is 19.3 per cent. of the value of the commodity.

Grain rates in general average less than those on any other commodity moving in large quantities, except coal. The grain rates which are here compared with those on copper are exceptionally low. Yet the rates on copper, in spite of its very great value, are much less than are these exceptionally low grain rates. It would be hard to find a lower rate per ton mile even on soft coal than the one of 2.85 mills on copper from Omaha to New York City; and while a 60,000 pound car load of copper is worth $\$ 7,500$, a 100,000 pound car load of soft coal might be worth less than $\$ 100$. The existing rates on copper were in effect in 1907, when it was worth $22 \frac{1}{2}$ cents per pound, or $\$ 13,200$ per car load. The freight charge for the haul of 1,400 miles from Omaha to New York was then less than 1 per cent. of the value of the commodity, while the rates on corn were around 20 per cent. of its value.

Another example of unfair discrimination is the allowance of excessive divisions of through rates to so-called "tap line" railways. These are railways, usually small ones, owned by, or controlled by the same interests as, great industrial corporations, and originating traffic from their plants and delivering it to the trunk line railways. Many tap lines that have received divisions of rates are mere plant facilities and no more entitled to par- 
ticipate in a milway rate than a facility composed of horses and a truck would be if the company chose to team its goods to the railway. Even when tap lines are really common carriers they very commonly get larger allowances of various kinds from the trunk lines than they are entitled to. In one case ${ }^{1}$ the Interstate Commerce Commission held that a tap line which switched cars no more than four miles was entitled to no more than three dollars a car for the service, basing its ruling on the amounts railways pay and receive for switching cars for each other. Numerous tap lines are still receiving allowances much in excess of this in proportion to the services they render. It is one of the many inconsistencies of our laws that the "Carmack Amendment" to the Hepburn Act forbids railways to haul commercial products belonging to them while it allows industrial corporations to own railways, many of them thousands of miles long, which are sometimes used to secure and perpetuate the most odious discriminations.

Another widespread abuse, which an investigation by the Interstate Commerce Commission disclosed in 1909, was what is technically known as "substitution of tonnage at transit points." 2 The transit arrangement gives to the shipper the privi-

Re-Divisions of Joint Rates, 10 I. C. C., 385.

2 In Re-Subdivision of Tonnage at Transit Points, $18 \mathrm{I}$. C. C., 280 . 
lege of stopping a commodity in course of transportation, holding it for such period and making such changes in it as may be specified in the tariff, and then forwarding it, all for the through rate from the point of origin, to final destination. If a grain dealer ships wheat from South Dakota to Chicago and sells and delivers it to a local miller there, and subsequently buys wheat from, say, a point in Illinois and ships it to the East, he ought to pay on the wheat from South Dakota the local rate to Chicago, and on the Illinois wheat the local rate from Illinois to the East. But if a grain dealer ships wheat from a point in South Dakota to Chicago, puts it in an elevator there, keeps it for a while and then ships it out to the East, he is required, by transit rules, to pay only the through rate from South Dakota to the ultimate destination. By means of substitution of tonnage, shippers at many transit points have got the benefit of the through rate on what were really local shipments. For example, the local rate from the Missouri River to Chicago on wheat was 12 cents per 100 pounds, and the local rate from Chicago to the Ohio River was 7 cents, the total sum being 19 cents. The through rate from the Missouri River, via Chicago, to the Ohio River on a transit basis was 13 cents, or 6 cents less. A practice grew up under which the dealer who sold in Chicago, or shipped out from there by boat, grain from the Missouri River, subsequently took the balance of 


\section{THE AMERIOAN TRANSPORTATION QUESTION}

the through billing and shipled out on it to the Ohio River grain which originated at points in Illinois South and East of Chicago and which was not entitled to the transit privilege to the Southeast through Chicago. He made two local shipments, one from the Missouri River to Chicago, and one from Chicago to the Southeast. He ought to have paid on them the sum of the two local rates, 19 cents. What he did was to so use his through billing from the Missouri River via Chicago to the Southeast as to get a rate of 13 cents, securing thus a rebate of 6 cents, or almost 30 per cent. As the transit privilege is not granted at all points, and as the opportunities for thus substituting tonnage are not equally good at all markets, this sort of abuse operates as an unfair discrimination both between shippers and between markets. Since the investigation by the Interstate Commerce Commission there has been less abuse of the transit privilege, but it has not been entirely stopped, and shippers at some places show a disposition to fight every rule proposed to stop it.

Another form of abuse that has developed since the Hepburn Act went into effect has been the occasional presentation by shippers and allowance by railways of excessive claims for loss of and damage to freight. Again, the railways make special rates for "return shipments"; that is, for the return of goods to the shipper when they are in a damaged condition on reaching the consignee, 


\section{DISCRIMINATION-REMEDIES}

or because he will not receive them; and large corporations have been caught making original shipments from branch houses on these low rates in the guise of return shipments.

Examples of still existent preferences and advantages might be further multiplied. Enough have been cited to show that unjust discriminations between shippers have not been extirpated. Why do they continue? Is it because shippers and railway men are incorrigibly unscrupulous? This is not the explanation. It is simply because, while most shippers and most railway men want to deal fairly and obey the law, there is a minority who still brave the statutes to get unfair advantages. The shipper who wants to gain an undue preference over his competitors goes shopping among the railways, tempting or putting pressure on their officers by offering, or threatening the withdrawal of, traffic. He is apt finally to find some traffic manager whose hunger for more business or apprehension of the loss of present business exceeds his scruples and his fear of the law. When a shipper has got an unfair concession from one road he at once demands it from others, under threat of withdrawing business from roads that do not give it. Competing shippers demand the same concession, both from the first road and from others which, for competitive reasons, grant it. Thus, when the unsci'upulous railway man and the unscrupulous shipper strike hands there is the be- 


\section{THE AMERICAN TRANSPOR'TATION QUESTION}

ginning of unfair rates of allowances by all the competing railways to all the competing shippers whose business is worth bidding for. In other words, as I have remarked before, the policy of our law is to compel unrestricted railway competition; and unfair discrimination between shippers, as well as between commodities and localities, is the offspring of excessive competition. As Martin A. Knapp, formerly Chairman of the Interstate Commerce Commission, and now Chief Justice of the Commerce Court, has said: ${ }^{1}$

The evils which have attended the growth and management of our railway systems and which have provoked so much public indignation have their origin and inducement for the most part in the competition of carriers, which it is still our legislative policy to enforce. . . . It is simply out of the question to have at the same time the presence of competition and the absence of discrimination.

Many people think that railway men unfairly discriminate from mere mischievousness of spirit. The fact is, that railway managers have been trying to stop unjust discrimination for many years, simply because such discrimination decimates railway revenues. Before the passage of the Act to Regulate Commerce they formed pools to maintain rates and prevent unfair discrimination. The Act

'Speech at the dimner of the Railway Business Association, New York City. November 22, 1910. 
to Regulate Commerce, passed in 1887, prohibited both unfair discrimination and pooling. The public objected to pooling because it was thought that whatever restricted competition tended to make rates high. Most authorities think that it did not tend to make rates unduly high, ${ }^{1}$ and that it did tend to reduce discrimination. After the Act to Regulate Commerce went into effect the railways formed traffic associations, having the same purposes as pools of competitive traffic or earnings. These were declared by the Supreme Court of the United States in the Trans-Missouri ${ }^{2}$ and the Joint Traffic Association cases to be in violation of the Sherman Antitrust Act. It held that any com-

1 "It does not seem, moreover, that the pools were a detriment to the public. Although the rival railroads made their rates by joint action, and united to maintain the charges thus agreed upon, they were not able to control the industrial forces to which transportation charges are in a large measure subject. Nor was it possible for the railroads by means of rate agreements and pools to prevent the ocean, the large rivers, and the Great Lakes from exercising a wide and effective influence on rail rates. From 1870, when pooling began, to 1887 , when it was prohibited by law, the average receipts of the railroads of the United States for hauling a ton of freight one mile declined from nearly two cents (in gold) to about one cent; in other words, the average ton-mile earnings in 1887 were only a little more than half those of 1870. Charges did not decrease because of pools, but the pools did not prevent their decline." - “American Railway Transportation," by Professor Emory R. Johnson, pp. 238, 239.

2166 U. S., 290. 
bination between railways, reasonable or unreasonable, to restrict competition was unlawful. The effect of the legislation against pooling and of the decisions of the Supreme Court in these cases was to stimulate the tendency toward railway consolidation. As Professor Johnson says: ${ }^{1}$

For many years the rival companies sought to prevent competition from producing its undesirable results by rate and traffic agreements; but when it became impracticable for the railroads, either directly or indirectly, to effect such agreements, the only available course of action was to secure unity of management by such consolidation as would tend to divide the field. Undoubtedly, the railway consolidations would have taken place and the strong systems would have continued to become larger had the Interstate Commerce Law permitted pooling and had the courts not held the antitrust law to apply to rate agreements; but the incentive to consolidation would have been less urgent and the process would probably have been slower.

To prevent unfair discrimination, it was necessary for the roads to coöperate in order to keep competition within reasonable limits. But the Sherman Act forbade such coöperation; it equally, as the Supreme Court later held in the Northern Securities case, forbade consolidation. Finding it necessary, as they believed, to break one law or

1“American Railway Transportation," page 251. 
the other, the railways chose what seemed the lesser of two evils, and broke, and probably, in some instances, are still breaking, the Sherman Law. But they dared not violate it as openly as was necessary entirely to prevent unfair discrimination; so the effect of the decisions under the Sherman Law and of the enforcement of the Interstate Commerce Act has been to cause the latter to be obeyed somewhat better than formerly, but not entirely; and to cause the former to be pretty frequently disobeyed in spirit, if not in letter.

Government regulation of railways has no more important object than the complete suppression and prevention of unjust discrimination. Past experience shows that to accomplish this the adoption of at least two means are necessary:

First. The Interstate Commerce Act and the Sherman Law should be so amended as to permit reasonable concerted action by railways regarding competitive rates. It is no longer necessary, in order to keep rates from being maintained at, or being raised to, unreasonable heights, to forbid such concerted action. The Hepburn Act gives the Interstate Commerce Commission authority to reduce any unreasonable rate and the Mann-Elkins Act gives it authority to restrain any proposed advance in rates, pending investigation, and to forbid it if found unreasonable. Why should we continue to forbid railways from acting together 
regarding competitive rates, when the Commission has ample power both to reduce, and to prevent the naking of, any excessive rate, whether made or proposed by one railway or by the concerted action of any number of railways?

Second. The Commission ought to be given the same authority to fix minimum, that it now has to fix maximum, rates. Unfair discrimination does not consist in making rates too high. It consists in establishing an unjust relation between thema relation which may exist either between two rates that are too low, or between two rates that are too high, or between one rate that is too high and another that is too low, or between one that is too high and another that is just high enough, or between one that is just high enough and another that is too low. Obviously, therefore, full authority justly to remove discriminations must include the power to raise a rate that is too low as well as to reduce one that is too high.

It may be said that when a discrimination consists in the fact that one rate is too low as compared with another, the railways can remove it by raising the lower rate. But while any one of a number of competing railways can reduce a rate, it takes all of them to raise it. Now, it not infrequently happens that the same men who control a big industrial concern having a large traffic, also own a large, or even controlling part of the stock of one of a number of competing railways 76 
and have representatives on its board, and that they use their influence over this railway to get it to make unfairly low rates on the commodities of the industrial concern in which they are interested. There is no power under existing law by which a railway thus dominated for the benefit of an industrial concern can be compelled to raise a rate paid by that concern. But to permit it to make disproportionately low rates on commodities in which some of its stockholders and directors are interested is palpably unfair to its other stockholders, to other railways and to other shippers. It would seem plain that, in such circumstances, the Interstate Commerce Commission ought to have and to exercise the authority to compel the advance of an unreasonably low rate.

To get these changes in our laws and to get the laws against unjust discrimination enforced and obeyed, our great need is a more enlightened and a fairer public opinion on this subject. Public opinion too often fails to distinguish accurately between what is fair and wholesome, and what is unfair and harmful, in railway rates. It magnifies molehills into mountains and minimizes mountains into molehills. It condemns practices without which the railway business could not be salutarily conducted, and condones and even favors practices which are incompatible with its being even decently conducted.

Furthermore-and this is one of the main 
reasons why these abuses have been so persistent public opinion does not fairly apportion the blame for unjust discrimination. It visits the bulk of it; condemnation for them on railway managers, when, as a matter of fact, railway managers are no more responsible for them than are big shippers. In the great majority of cases it is the shipper who first suggests the discrimination, simply because he, not the railway, will be its chief beneficiary; and the public has little conception of how perseveringly many big shippers press for illegal concessions even after railway men have repeatedly protested against them on the ground of their injustice and unlawfulness. The big shipper has a great advantage over the railway traffic manager in business negotiations, because, while the railway, being a public service corporation, cannot legally retaliate on the shipper who discriminates against it by taking or withdrawing business from it, the shipper can retaliate on the railway that refuses to do his bidding, by taking his business entirely away from it; and the big shippers use ruthlessly the power that their ability to give or withhold traffic confers. As I have pointed out, in not a few cases the same interests that control a large industrial corporation also are large factors in one or more of a group of competing railways. When this is true, it is little short of a miracle if this industrial concern pays fair rates. 


\section{DISCRIMINATION-REMEDIES}

The big shippers always have succeeded in putting most of the odium for unfair discrimination on the railways while getting most of the benefits of it themselves. ${ }^{1}$ When an attempt is made to raise rates in which they are concerned their representatives are the first to appear before the Interstate Commerce Commission as tribunes of the people. The public is apt to forget that no rebate, or other form of unfair discrimination, was ever given that somebody did not receive. It should not condemn the railways any more severely than it has in the past for unjust practices; but it needs to learn that the big shippers are working for their own pockets all the time; that every unfairly low rate and every unjust concession that they get, like every secret rebate, either deprives the railway of the ability to earn a fair return or makes it necessary for other shippers to pay higher rates than they ought to be required to pay; and

${ }^{1}$ The success the big shippers have had in getting illegal favors from the railways, and then causing the railways alone to be punished for giving them, reminds me of a joke played by an old friend of mine down in Missouri. He was the most inveterate practical joker I ever knew. Once when he was very sick an intimate friend went out and shot some quail to provide him with a delicate repast. The old gentleman, while ill, was very appreciative. But "The Devil was sick, the Devil a monk would be; the Devil was well, the Devil a monk was he." As soon as my old friend had recovered he went before a justice of the peace and had the Nimrod fined for hunting out of season in violation of the state game laws! 
that, therefore, the shipper who gets and benefits by an unfair discrimination deserves just as severe condemnation and punishment as the railway man who gives it. We will never stop unjust discrimination, never get fair and salutary regulation of rates, until the public clearly and fully recognizes the fact that in the public interest it is just as needful that public regulation shall protect the railway from the shipper as it is that it shall protect the shipper from the railway. 


\section{CHAPTER V}

\section{RAILWAY VALUATION AND PROFITS}

UNTIL lately the main problem, and aim, of regulation of railways was the suppression of unfair discrimination in rates between commodities, communities and persons. Different states had passed laws to reduce entire schedules on the ground that they were excessive; but often the belief that they were excessive grew out of comparisons between them and lower rates in other states. It was generally agreed that, on the average, American railway rates were reasonable. But recently the questions-of what are the correct standards for determining whether the rates as a whole of each of our railways, and of all of them, are excessive or unremunerative, or just the happy mean between these two extremes; and of how, when entire schedules are found unreasonable, they shall be made reasonable-have become of paramount interest and importance.

The change is due to two causes. One is the reduction during the past five years in the number and perniciousness of unfair discriminations, which has made the question of their elimination relatively less important. The other is the con- 
troversy and struggle between travelers, shippers, and many public men, on the one side, and the managers of the railways, on the other, that have sprung from the belief of the former that rates as a whole are too high, and their attempts to reduce them, and the belief of the latter that rates are too low, and their attempts to raise them.

Economists have used three standards for measuring the reasonableness of entire schedules of rates. ${ }^{1}$ The first is their effect on traffic. If they hamper its movement and growth, that is conclusive proof that they exceed the value of the service rendered for them and are excessive; and the courts of this country will in that case reduce them, even if the effect be to disable the roads concerned from earning any profit whatever. ${ }^{2}$ The railway's right to a return is subordinate to the public's right to reasonable rates. Tested by their effect on traffic the rates of the railways of the United States as a whole cannot be regarded as unreasonable. In all parts of the country traffic moves freely, and grows as fast as, or faster than, facilities can be provided to handle it.

The second test economists have used is comparison between the rates in question and those of other railways. Owing to the great differences between the conditions under which railways are built and operated, this is seldom an easy standard

${ }^{1}$ Hadley, “Railroad Transportation," page 103.

"Rearin i's. Farmers' I wan and Trust Co., 154 U. S., 362. 
to apply. Rates that would be excessive on roads built and operated at small cost, and having a large traffic, would be reasonable on lines built and operated at large cost and having a small volume of traffic. Again, some railways handle a larger proportion than others of cheap, bulky commodities. These must be given comparatively low rates if they are to move freely; and they can be because they can be hauled in large car loads, or even in solid train loads, at relatively small cost. Then, some roads get much longer average hauls than others, which also tends to enable them to handle the traffic more cheaply and to make lower rates. Adequate weight must be given to such dissimilarities of conditions to make comparison of the rates of different railways at all useful.

Now, the railways of the United States have cost a great deal less than those of England, and substantially less than most of those of Europe.

On the other hand, the prices they have to pay for materials and labor with which to conduct their operations are much higher. Their density of passenger traffic is much less than that of the railways of Europe. On the other hand, their freight traffic is denser than that of the railways of Europe. This is both because it contains a larger proportion of cheap, bulky commodities, and because in Europe the railways handle the very valuable goods moving in small consignments which in this country are handled by separate car- 
riers-the express companies. For these reasons we should expect to find that the average rate per passenger per mile here is higher, and that the average rate per ton per mile is as low as, or lower than, in Europe. And this is the case. The average passenger rate in the United Kingdom is about 1.54 cents; in Germany, 9.3 mills; in France, 1.54 cents; and in the United States, 1.94 cents. The average rate per ton per mile in the United Kingdom is about 2 cents; in Germany, 1.27 cents; in France, 1.28 cents; and in the United States, .753 cents. Allowing fully for differences in conditions, rates in the United States as a whole are as low, if not lower, as anywhere else in the world.

The third test economists have applied in considering the reasonableness of rates as a whole is the net return on their capitalization received by the railways charging them. Measured by this standard also the rates of the railways of the United States are low. They have never in any year paid as much as 4 per cent. on both their bonds and stock. ${ }^{1}$

In recent years a new theory of the proper way to ascertain the reasonableness of rates has gained wide acceptance. Many believe that the railways of this country are overcapitalized. They think, therefore, that the return on their capitalization is not a criterion of the reasonableness of their

${ }^{\prime}$ Poor's Manual, 1910, page cxiv. 
rates. The sole true criterion, they believe, is a "fair return" on the "fair value" of the properties of the railways; a "fair return" is the current rate of interest; and therefore the government should make a valuation of the properties, and in future so regulate rates as to restrict net earnings to the current rate of interest on this valuation.

All agree that return to the owners of the railways should be considered, and given much weight, both in making and regulating rates. The differences of opinion arise over (1) the basis on which the return should be computed; (2) the percentage of it that should ordinarily be allowed to be earned; and (3) the weight that should be given to it in regulating rates, compared with the weight that should be given to other considerations.

Many believe that the just basis on which to compute the percentage of the net earnings of the railways in order to ascertain whether their rates are too high or too low is the capital that has been invested in them, exclusive of earnings. Large amounts of net earnings, that legally might have been paid out to the stockholders, have instead been invested in the properties. The properties also contain a large amount of so-called "unearned increment." It is argued that, as railways are public service corporations, their owners are not entitled to receive a return on those parts of their value which have been created by the investment 
of earnings or by increases in the value of real estate caused by the industrial development of the country.

The owners and managers contend, on the other hand, that in any estimate that may be made of the value of the properties on which a return should be allowed to be earned, every factor entering into their present value should be considered. The net earnings, they say, belong to the stockholders. They may either invest them or pay them out as dividends; and where they have chosen to invest them the value thereby added belongs to them. They also own the real estate used for railway purposes as absolutely-so long as it is used for railway purposes - as the farmer owns his farm; and therefore they have the same right, it is said, to profit by increases in its value.

From a legal standpoint the spokesmen for the railways seem to have the better of the argument. The fifth and fourteenth amendments to the Federal Constitution prohibit the Nation and the States from taking private property for public use without due process of law and just compensation. When the railway, in the exercise of the power of eminent domain, takes the farmer's land, these provisions are construed to mean that it must pay him for it-not what it cost him-but its reasonable market value at the time that it is taken. A similar construction of the same provisions as they apply to railways would require that rates should 
be so regulated as to enable the railways to earn a return on the value of their properties at the time that the rates are being regulated, however the value may have been created. For if the rates were so regulated as to disable the company from earning a return on any part of the value of its property this would be, in effect, to take so much of its value. The Supreme Court of the United States has, therefore, indicated that while the original cost of construction of public utilities, when ascertainable, should be considered, this is merely to get such light as it will throw on their present value. In a recent case involving the rates of a gas company it said: ${ }^{1}$

We concur with the court below in holding that the value of the property is to be determined as of the time when the inquiry is made regarding the rates. If the property which legally enters into the consideration of the question of rates has increased in value since it was acquired the company is entitled to the benefit of such increase.

The United States Circuit Court for the District of Minnesota recently held similarly in a case involving railway passenger and freight rates fixed by the state authorities of Minnesota. It said:

The costs of rights of way from 5 to 40 years ago through wild lands, and through towns and villages

${ }^{1}$ Wilcox vs. Consolidated Gas Company, 212 U. S., 19. 
Whose population and the value of the moperty in which have since multiplied by from 2 to 10 , is obviously no criterion of the value of those rights of way in 1908, when they were userl under these fares and rates and when agricultural lands in Minnesota were worth from $\$ 35$ to $\$ 100$ an acre, and rights of way and land for yards and sites for stations in cities like St. Paul and Duluth have wonderfully increased in value. It is a fair return upon the reasonable value of their Minnesota property in 1908 to which these companies were entitled, and the cost of that property at times varying from five to forty years ago may be some evidence; but it certainly is no criterion of its value in that year.

It costs on the average from one and one-third to three times as much to get land for railway as for other purposes. This is because its acquisition and use for railway purposes involve damage to adjacent property which must be paid for, and because land that is directly in the path of a coming railway attains a monopoly value. The Railroad Commission of Minnesota, in making its valuation of the railways of that state, ${ }^{1}$ held, however, that the appraisal of railway land should be based on the value of adjacent land used for other purposes.

But how, railway men ask, can what the farmer would have to pay for land properly be used as a factor in estimating what it would cost to repro-

'Twenty-fourth Annual Report of the Railroad and Warehouse Commission of Minnesota, 1908. 


\section{VALUATION AND PROFITS}

duce the railway? Suppose that adjacent farm land were worth $\$ 100$ an acre; that the valuation of an established railway were made on this basis; and that afterward there was built a new and competing line, to which the actual cost of land was $\$ 200$ an acre. The competitive rates on competing railways must be the same. If the rates of the older railway were to be so fixed as to restrict it to a return on $\$ 100$ an acre, the new railway would have to meet them and might thereby be deprived of the opportunity to earn a return on part of its actual investment. This would tend to discourage new railway construction.

The Railroad Commission of Washington met a situation similar to this when it made its valuation of the railways of that state. The Northern Pacific, many years ago, acquired land for extensive terminals on Puget Sound at a low price. The Harriman lines recently built to Puget Sound, and because of the increase in the value of land had to pay very much more for it. The two systems were competitors, and had to make the same competitive rates. To have based the valuation of the Northern Pacific's land on its original cost, or on its estimated value for other than railway purposes, might have prevented the Harriman lines from earning a fair return on the actual cost of their land. The Commission, therefore, based the valuation of the land of both roads on its present estimated cost of acquicition for railway purposes. 
In deciding the Minnesota rate case, Judge Sanborn of the Uniter States Circuit Court overruled the Minnesota Commission and held that the proper basis of valuation of land owned by a railway and used for transportation purposes, is what it would now cost the railway to acquire it for those purposes, even though that would be much more than it would cost to acquire it for any other purpose.

Another important point in estimating the cost of reproducing the physical plants of railways, is what deduction should be made for depreciation, and what addition should be made for appreciation, in the value of their various parts. The moment a rail or tie is laid, or a signal tower or station is finished, it begins to deteriorate, owing to use, and the ordinarily insidious, but often violent, ravages of the elements. All of the state commissions that have made valuations of railways have, to arrive at their present value, made deductions for depreciation from their estimated cost of reproduction new. But, say railway men, while the depreciation is going on there is also appreciation going on. As soon as a new line is finished maintenance forces are put to work, if it is well managed, which limit the depreciation that takes place by making constant repairs and renewals. And by their efforts, by the pressure and pounding of trains, and the action of sun and rain, of frost and heat, of drought and flood, weaknesses in fills are 
disclosed and remedied, watercourses are established, roadbed and embankments are solidified, and, throughout a period of fully ten years, the transportation machine is better and better adapted to its purpose. Therefore, an old railway which has been well maintained is physically a more valuable property than a new one; and, railway men contend, if a deduction from the cost of reproduction should be made because of depreciation, an addition to it should be made ${ }^{1}$ because of appreciation.

According to the widely accepted theory, as soon as an estimate of the cost of physical reproduction is finished, we should go ahead and so regulate rates on it as to limit each carrier to the same return. But is such an estimate a valuation?

' This contention was upheld by Circuit Judge Sanborn in the Minnesota rate case. He said: "Whether at a given time a railroad property is more or less valuable than it would be if it had just been constructed is a question of fact, that in a suit of this nature must be answered by the evidence. That evidence in this case is that the railroads, rolling stock, and appurtenances which constitute the great transportation machines of these companies in Minnesota are in better condition for use, more efficient, more stearfast, better adapted to each other, than if their construction was just completed, that all depreciation has been offset by appreciation, and that values to the amounts here allowed hy the master have been adred to the values of these properties new, by their age, their repairs, their renewals, their adaptation and the assured efficiency that comes from constant careful maintendnce and operation. There was no error in these allowances." 
Indubitably, other things being equal, a railway having a good physical plant is more valuable than one having a poor one. But, surely, the estimated cost of reproducing a railroad's plant is not the value of the plant; and the value of the plant is not the value of the railroad.

A railway through mountainous country might be more expensive to reproduce than one built through easy prairie country; but the latter's plant may be the more valuable, simply because it is the better machine for rendering transportation.

Again, of two roads having equally good physical plants, that having the larger net earnings is plainly the more valuable. Now, net earnings do not depend solely on rates. They are the margin between gross earnings and operating expenses. Gross earnings depend not only on the rates charged, but on the nature and density of traffic. These, in turn, result largely from the energy and skill used by the traffic department of the railway in attracting population to its lines, teaching the farmers how to increase the productivity of the soil, securing the opening of mines and the location of factories, and so adjusting rates as to enable producers in the territory to compete successfully in the markets of the entire country and of the world against the producers in other sections and countries. Whether operating expenses shall be high or low in proportion to gross earnings depends on the enterprise and skill used by the man- 
agement in reducing the grades and eliminating the curvature in track, in enlarging terminals, developing esprit de corps among officers and employees, increasing shop efficiency, augmenting tonnage per ear and per train load, and in a hundred other elements of good management. A road whose traffic is large and whose operating expenses are relatively small, obviously would have larger net earnings, and, therefore, be a more valuable property, than a road on which the traffic is relatively small and the operating expenses relatively high, on any basis of rates whatever that might be applied on both. The Union Pacific and the Denver \& Rio Grande, for example, are competing lines. Both the average freight rate and the average passenger rate of the Union Pacific in 1909 were a little lower than those of the Denver \& Rio Grande. But owing to the greater density of traffic of the Union Pacific and its lower operating expenses per unit of traffic handled, its net earnings were $\$ 7,308$ per mile, while those of the Denver \& Rio Grande were but $\$ 2,535$ per mile. ${ }^{1}$

${ }^{1}$ The figures in detail are as follows:

Union Denver \&

Pacific. RioGrande.

(Year ending June 30, 1909)

Average rate per passenger per mile........ 1.959 eents. 1.997 cents.

Average rate per ton per mile............... 1.004 cents. 1.305 cents.

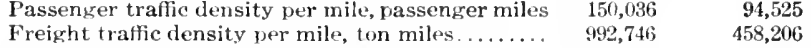

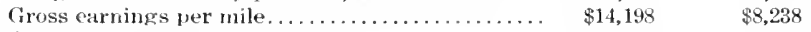

Operating exponses per mile............. $\$ 6,890 \quad \$ 5,703$

Net earnings per mile. . . . . . . . . . . . . . . $\ldots \ldots \quad \$ 7,308 \quad \$ 2,535$

It will be noted that the operating expenses of the Union 93 
Athough thoir ates were practically the same, if you capitalize their net earnings at 7 per cent. you get a valuation of $\$ 102,312$ per mile for the Union Pacific and one of only $\$ 35,490$ for the Denver \& Rio Grande. As it renders more service to the public and earns more money for its owners, the road having the greater density of traffic and the proportionately lower operating expenses is the more valuable to both. Is it not, therefore, entitled to the higher valuation?

Large traffic and relatively low operating expenses are strong evidences of good management. If valuation were based entirely on the cost of physical reproduction, and the net earnings of each road could be, and were, limited to the same amount, the better managed roads would be deprived of the fruits of their good management.

As a matter of fact, such regulation probably would be entirely impracticable; for the competitive rates on different roads must be the same; and, owing to the differences in density of traffic

Pacitic were absolutely larger per mile than those of the Denver \& Rio Grande, although smaller in moportion to gross earnings. If the Denvel \& Rin Grande's equipment, roalway and structures had been as well maintained as those of the Union Pacific, its opelating expenses would have been much larger and its net carnings mueh smaller. A similar contlast could he made be tweral roads in any part of the enontry : for :xample, in the Mirdle West, between the ('hicage Great Western, on the one hatne, and the Chicagn \& North-Western and the Chicago, Burlington \& Quiney on the other. 


\section{VALUATION ANI PROFITS}

and operating expenses, no two roads charging the same rates could be made to carn the same percentages on their valuations. The theory that rates should be based on physical valuation alone assumes that the percentage of net earnings on the physical valuation is the measure of the reasonableness of the rates. As on the same rates one road might earn very much more than what might be considered a "fair return," and another, having a relatively lighter traffic and relatively higher operating expenses, much less, it would follow, on this theory, that the same rates might be at once both reasonable and unreasonable! The road having the larger percentage of net earnings might, by less skillful management, so reduce its density of traffic and increase its operating expenses as, without any change in the rates, to reduce its net earnings to a "fair return." On the theory in question, this would make reasonable the rates which previously, as to it, were unreasonable. A theory so easily susceptible of a reductio ad absurdum cannot be entirely correct.

The Supreme Court of the United States has clearly held that the value of a railway consists not merely in its physical plant but also in the actual use and usefulness of the property. It said in a railway tax case: ${ }^{1}$

But the value of property results from the use to ${ }^{2}$ C. C. C. \& St. L. $v ' s$. Backus, 154 U. S., 445. 
which it is put and varies with the profitableness of that use, present and prospective, actual and anticipated. There is no pecuniary value outside of that which results from such use. Will it be said that the taxation must be based simply on cost when never was it held that cost of a thing is the test of its value? Suppose there be two bridges over the Ohio, the cost of construction of each being the same, one between Cincinnati and Newport, and the other 20 miles below, where there is nothing but a village on either shore. The value of the one will, manifestly, be greater than that of the other, and that excess of value will spring solely from the larger use of the one than of the other.

The advocates of exclusively physical valuation rely fo: legal support mainly on the decision of the Supreme Court of the United States in the Nebraska rate case. ${ }^{1}$ But Justice Harlan, in the opinion of the court in that case, mentioned not only the cost of original construction and permanent improvements and the cost of reproduction as factors to be considered, but also the amount and market value of stocks and bonds outstanding; the sum required to meet operating expenses, and the probable earning capacity of the r"operty under the particular rates prescribed by statute. The probable earning capacity of the property under any rates depends on the nature and density of the traffic. Ilere, therefore, we have, by direct

${ }^{1}$ Smythe i's. Ames, 169 U. S., 466. 


\section{VALUATION AND PROFITS}

implication, a ruling of the Supreme Court that the density and nature of the traffic and the operating expenses must be considered in making a valuation.

While it is easily shown that of two railways with equally good physical plants, that having the relatively larger business and the relatively lower operating expenses is the more valuable, the value of a difference in volume or quality of traffic, or in operating expenses, cannot be expressed in terms of money until it emerges in net earnings; and it can only emerge in net earnings after rates expressed in money have been applied to the traffic. But there is, perhaps, a way in which, while using physical valuation as a basis for regulating rates and profits, we might secure to each road the benefit of every element entering into its total value as a going concern.

It might be found, if a general physical valuation were made, that some roads could not earn a fair return on their valuations without charging rates which would interfere with the movement and growth of traffic. They would have to be denied it, for, as has already been said, the right of a railway to earn any return is subordinate to the right of shippers and travelers to reasonable rates.

Just above this class of railways would be found others in all parts of the country, which would, perhaps, be barely able, with rates that would not oppress the traffic, to earn the current rate of in- 
terest on the estimated cost of physically reproducing them. The courts have indicated that if a railway, without levying exorbitant charges, can earn a "fair return" on the "fair value" of its property it cannot be denied the opportunity to do so; this would be confiscation. They would hardly hold in any case that the cost of reproducing the physical property exceeded the fair value of such a railway; or that the current rate of interest exceeded a fair return. It would seem, therefore, that railways of this class could not be restricted to less than the current rate of interest on their physical valuations.

Still above them would be found roads, which, on the same rates, could earn more, and in some cases much more, than the current rate of interest on their physical valuations. Should they be permitted to do so? While they would earn larger percentages of return on their physical value, their percentages of return on their total value, including their physical value and their utility to the public and to their owners, as evidenced by the amount of business that they handled and the economy and efficiency with which they handled it, might be no larger. Even if some railways did earn large profits this might not be proof that their rates were excessive. The fact that other ordinarily well and prudently managed roads in the same territory, charging the same rates, earned no more than a fair return on the physical value of their 


\section{VALUATION AND PROFITS}

properties would be evidence that the rates were reasonable and that, therefore, the more prosperous roads were entitled to their large profits. The Supreme Court of the United States has never held that a railway is not entitled to earn more than a fair return. What it has held, in Smythe vs. Ames and other cases, is that a public service corporation, so long as it does not charge unreasonable rates, cannot be restricted to less than this. Justice Brewer in Cotting vs. Goddard, ${ }^{1}$ a case involving the rates of a stock yards company, said:

As to parties engaged in a public service, while the power to regulate has been sustained, negatively the (Supreme) Court has held that the legislature may not prescribe rates, which, if enforced, would amount to confiscation of property. But it has not held that the legislature may enforce rates that stop only this side of confiscation.

In another part of the same opinion he said:

But it does not follow, therefore, that the legislature has power to reduce any reasonable charges because by reason of the volume of business done by the party he is making more profit than others in the same business. . . The amount of the aggregate profits may be a factor in considering the reasonableness of the charges, but it is only one factor and is not that which finally determines the question of reasonalleness.

$$
183 \text { U. S., } 75 .
$$


Nor have the courts ever held that the current rate of interest or any other specified percentage is a "fair return" under all circumstances. The Supreme Court in the Consoliclated Gas case ${ }^{1}$ said:

There is nu particular rate of compensation which must, in all cases and in all parts of the country, be regarded as sufticient for cipital invested in business enterprise. Such compensation must depend greatly on circumstances and locality; among other things, the amount of risk in the business is a most important factor, as well as the locality where the business is conducted, and the rate expected and usually realized there upon investments of a somewhat similar nature with regard to the risk attending them. There may be other matters, which, in some cases, might also be properly taken into account in determining the rate which an investor might properly expect.

The Supreme Court held in this case that the Consolidated Gas Company, the risk in the investment in which was pronounced very small, was entitled to 6 per cent.

The United States Circuit Court in the Minnesota rate case held that the railways in Minnesota were entitled to 7 per cent., saying:

To deprive them of such a return would prevent advances and tend to compel reductions in the wages and salaries of their employees, would tend to prevent the extension of their lines into portions of the state

${ }^{1}$ Wilcox $v$ s. Consolidated Gas Company, 212 U. S., 19. 


\section{VALUATION AND PROFITS}

where the development and accommodation that railroad service assures would be welcome and may be needed, to deteriorate the character of the service they render, and to retard the general prosperity. The legal rate of interest on a debt in Minnesota, in the absence of contract, is 6 per cent., and by contract it may be 10 per cent. per annum. Rational investments in agricultural, manufacturing, mercantile, and other industrial pursuits, and even well-secured loans, yield returns in Minnesota corresponding with these lawful rates. Investments in railroads and the returns thereon are at the risk of failures and partial failures of crops, of the disasters, delays, and expenses of unusual storms, snow and cold, of the great financial disasters which occasionally prevent or delay the movement of traffic, and of the burden of continuous operation, whether profitable or unremunerative. It is an axiom in economics that the greater the risk the greater must the return be upon invested capital, and the conclusion is irresistible that a net return of 7 per cent. per annum upon the respective values of the properties of these companies in Minnesota devoted to transportation is not more than the fair return to which they are entitled under the Constitution of the United States.

Letting the more successfully managed roads earn more than the less successfully managed would tend to foster efficient management on all; no stimulus to the use of enterprise and skill is so potent as allowing enterprise and skill to garner and enjoy the fruits that they have nurtured. 
Wages are the compensation labor receives for its services. Profits are the compensation investors in railways receive for their public service in furnishing transportation. There has been much discussion recently of the subject of "scientific management." The managements of the railways, and of other concerns, have been criticised for not more generally applying its principles to their operations. Now, fundamentally, scientific management consists in adopting such conditions of employment, and such schemes of compensation for labor, as will secure for the employee and the employer the maximum returns for a given expenditure of energy by the employee and a given investment of capital and expenditure in wages by the employer. The principal means to these ends commonly used is to fix a standard wage less than which no employee will be paid, and to then pay extra wages for the exertion by employees of more than average skill and energy, these extra wage payments being so adjusted that as a result of them the employer will get each unit of the products of labor at a smaller cost. The idea is that both employee and employer receive the largest benefits from their joint endeavors when each employee is paid in proportion to the quality and quantity of the work that he does. Opposed to this scheme of scientific management is the plan usually favored by the leaders of the labor unions, of paying the same scale of wages to all men doing 


\section{VALUATION AND PROFITS}

the same kind of work, in substantial disregard of the amount and the quality of the work that they do. Those who advocate "scientific management" condemn the labor union plan of "each for all and all for each" on the ground that it does not stimulate, but retards, individual effort; and that only by stimulating individual effort can the cost of production be kept down to the minimum and the return to both labor and capital be raised to the maximum.

Now, the managements of railways and other business concerns are strictly comparable to individual workingmen. Some managements have great ability and enterprise; some only the ordinary amount; some almost none. The public occupies a position analogous to the employer, and the railway to the employee. The public employs the railways to render the service of transportation. As I have shown, it would be impossible, merely by regulation of rates on the basis of valuation, to restrict all competing railways to the same return, because, owing to differences in the operating expenses, in the density of traffic and in other characteristics of competing railways, they are bound, when they charge the same rates, to earn different net amounts. It has, therefore, been suggested by one eminent economist that all net earnings in excess of a "fair return" be appropriated by the public. Suppose, for example, that a fair return for railways in a certain territory 
were held to be 7 per cent. and that some of the roads were able to earn 10 per cent. Under the plan suggested the extra 3 per cent. would be taken by the public in the form of taxes.

It is questionable if this could constitutionally be done. It is also questionable if, in case it were constitutional, it should be done. For this would be applying to railways the very principle of compensation which those who advocate scientific management oppose applying to the compensation of labor; and its tendency would be to deprive railway managements of initiative and enterprise. At present improvements are undertaken with the hope of increasing profits, but always with the knowledge that their cost may exceed their worth. A reduction of grades is a permanent improvement. It should properly be charged to capital account. Its two effects are to reduce the cost of running trains-in other words, to reduce operating expenses-and to increase fixed charges in proportion to the investment involved. Whether it results profitably depends on whether it reduces operating expenses or increases fixed charges the more. If it has the former effect the road gains; if the latter, it loses. Under the proposed policy, if an attempted improvement turned out unprofitably the road would have to pocket the loss, until it could get an increase in raies or until the growth of traffic made it whole; while if it turned out well none of the benefit would go to the railway's 10.4 
stockholders in increased dividends, but all would go to shippers and travelers in the form of reduced rates, or to the public in the form of increased taxes. Under such a policy railway managements would not be keen to undertake improvements. They would be more apt to be so inefficient that increases in operating expenses would take place which would raise the cost of transportation.'

The application of the principles of scientific management to the railways would involve permitting them to earn returns increasing with, although perhaps not in proportion to, the energy and skill with which they were managed. Such a policy would be much better adapted to fostering economical and efficient management than one of

${ }^{1}$ It will be recalled that it was Mr. Louis D. Brandeis who, appearing before the Interstate Commerce Commission in the so-called Rate Advance Cases as counsel for certain shippers, contended that the railways should get such increased net earnings as they might need by augmenting the efficiency of their operations and not by advancing their rates. Testifying subsequently before the Railway Securities Commission, of which President Hadley of Yale was chairman, and which was created by Congress to investigate the question of whether the issuance of railway securities should be subjected to supervision by the government, Mr. Brandeis made an argument following the same line that I have taken in the text. My own discussion of the question, as it appears in the text, was written before Mr. Brandeis' testimony was given. Mr. Brandeis said:

"To-day efliciency in management is in danger of being punished, whereas it should be rewarded. Efficiency is naturally reflected in large net earnings; and as no ready means 
limiting all the railways to the same return, whether that return were made high or low. And the results would be much more likely to be beneficial to the public.

The total gross earnings of the railways of the United States in the year ending June 30, 1910, were $\$ 2,750,667,435$; their operating expenses, $\$ 1,822,630,433$. The interest on their funded debt may, perhaps, be regarded as a practically irreducible amount; limitation of their profits can affect only the dividends they pay. The net dividends paid by them-that is, the dividends on stock not owned by railways, but outstanding in the hands of the public-were almost $\$ 294,000,000$, or less than 11 per cent. of their total earnings.

exist for determining whether greater net earnings are due to greater efficiency in management, or to higher rates, large earnings are frequently accepted as evidence that rates are too high, and invite a demand for reduction; whereas, in fact, the large earnings may be due wholly to better judgment, greater efficiency, and economy in administration. To take from railroad corporations the natural fruits of efficiency-that is, greater money rewards-must create a sense of injustice suffered, which paralyzes effort, invites inefficiency, and produces slipshod management. . . . Private capital embarked in a quasi-public business ought to receive compensation on a sliding scale, so that the greater the service to the public, the greater the profit to those furnishing that service. We should endeavor to approximate results similar to those obtained in Boston by applying the sliding scale system to the production and sale of gas. There the dividend to the stockholders rises as the selling price to the public is reduced." 
Therefore, if their dividends were entirely wiped out the public's bill for transportation could thereby be reduced less than 11 per cent., and if they were doubled its transportation bill would thereby be increased less than 11 per cent. The vast bulk of the money they collect from the public is paid out for operating expenses, which amount to six and one-half times as much as their net dividends. Obviously, therefore, there is much more chance for the public to gain largely by adopting a policy which will tend to keep down or reduce railway operating expenses than one that will tend to keep down or reduce dividends. Ten per cent. of the operating expenses equals 62 per cent. of the dividends. The courts hold that the railways cannot be restricted to less than a "fair return"-say 6 or 7 per cent. Suppose that the public at the same time provides that no railway shall have more than this. Thus assured of a minimum return and restricted to this as a maximum, the railways would be deprived of all incentive to economical operation. This might easily result in an increase of 10 per cent. in operating expenses-or prevent a reduction of 10 per cent., which comes to about the same thing. This, being shifted to the shoulders of the public, would amount to as much in its effects as a 62 per cent. increase of dividends. If, on the other hand, the public should adopt the policy of rewarding each road according to its deserts, and this should cause a 10 per cent. reduc107 
tion in operating expenses, the reduction in the economic cost of transportation would be equal to il $6: 2$ per cent. reduction in dividends.

These figures show conclusively that there is much more chance for the public to gain largely by stimulating the railways to adopt more economical and efficient methods of operation than by restricting their profits; and experience indicates that the public would share in the benefits of better management. It has received a large share of the benefit of the ever-increasing economy and efficiency of railway operation in the past in the form of reduced rates, or of rates which remained nearly stationary while the wages of labor and the prices of commodities were generally rising, which are equivalent to reduced rates. If the public prefers in future to receive its share of the benefits of the growth of traffic and of more efficient management in the form of higher taxes, instead of low rates, the suggestion that earnings in excess of the percentage held by the courts to be a fair return be appropriated in taxes might be adopted in a modified form. It might be provided-assuming this would be constitutional, which it probably would not be--that all earnings in excess of, say, 7 per cent. should be divided equally between the railway and the public, the public's share being paid into the treasuries of the states through which each railway operates in proportion to its mileage in the different states. This would be 108 
much better adapted to securing efficient and economical management than the limitation of all railways to the same maximum return. It would not tend to prevent all reductions in rates, for many reductions so greatly stimulate the growth of traffic as to increase net earnings; and the railways would still have an incentive to do anything that would increase their net earnings. It might protect the roads against some unreasonable demands of shippers; for whatever reductions in rates reduced net earnings would reduce the public's share of them as well as the railway's share.

It is sometimes contended that after a valuation is made rates should be so regulated as to restrict the most prosperous carriers to a fair return. As the competitive rates of competing railways must be the same, the result would be either (1) to restrict the weaker lines to less than a fair return, or (2) to cause them to get a fair return by making their rates at non-competitive points very much higher in proportion than their rates to competitive points. The decisions of the courts seem clearly to hold that so long as a road does not make its rates so high that the traffic cannot easily move it cannot be restricted to less than a fair return. It seems to follow that to restrict the earnings of the stronger roads to the so-called "fair return" would be, in effect, to justify the weaker roads in making their rates to non-competitive points relatively much higher than those to 
competitive points. Thus the proposed policy might have the effect not only of impairing railway efficiency, but of causing very injurious discriminations against many communities. It has been one of the main purposes of past regulation to prevent such discriminations. 


\section{CHAPTER VI}

\section{RAILWAY VALUATION AND PROFITS (Continued)}

I HAVE tried to outline in the previous chapter the only way in which, it would seem, a valuation could be made which would stand the test of the courts, and the only way in which, apparently, it could be used as a basis for the regulation of rates without impairing railway efficiency and injuring rather than benefiting the public. What would be the results of an attempt to carry out such a policy is largely a speculative matter.

The making of a valuation of our entire 240,000 miles of railway would involve a very heavy initial expenditure by the government. The appraisal would have constantly to be revised, for a railway's value, owing to improvements, and variations in the value of its land, may change greatly from year to year; and, as we have seen, the courts hold that it is the value at the time that the inquiry is being made regarding the rates that must be considered. Therefore, there would have to be continuing expenditures to keep the valuation up to date. While the initial valuation was in progress investors and railway managers would have a feeling of some uncertainty as to the results of its making and its use, which, like uncertainty regarding public action affecting any large industry, would tend to retard railway development and 111 
cause more or less depression in business in general. It is probable the final results would be surprising to most people. The major premise in the argument for valuation has been that our railways are overcapitalized and that, therefore, the return on their capitalization cannot be used as one of the tests of the reasonableness of rates. Some of our railways are overcapitalized-certain of them grossly so. But on the average they have the lowest capitalization per mile of the railways of any first-rate country in the world, and a much lower capitalization than those of many second-rate countries. ${ }^{1}$ They make annual reports of the cost

1 The capitalization (or costs of construction) per mile of the railways of the United States and those of some other countries as reported for the years mentioned are as follows :

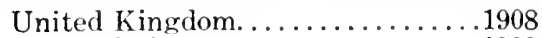

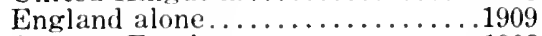

German Empire ................ 1908

France....................... 1907

Austria .......................1907

Hungary .................................

Italy *.................... 1907-8

Spain ..............................

Portugal ........................ 1905

Sweden......................... 1906

Norway . . . . . . . . . . . . . . . . . .1908

Denmark * ..................1907-8

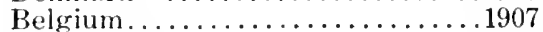

Holland ....................1907

Switzerland ..................1907

Roumania...................19197-8

Argentina . . . . . . . . . . . . . . . . 1907

Japan *. . . . . . . . . . . . . . . . . . 1908

British Indial.................... 1908

New South Wales ................1909

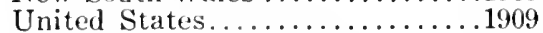

$\$ 275,040$

314,000

109,788

139,237

112,875

63,011

$124,583 \dagger$

77,077

113,954

33,678

38,458

50,215

$157,298+$

86,211

110,740

92,719

59,930

47,758

43,364

63,999

59,259

\section{* State only.}

$\dagger$ Canital 1906-1907.

$\$$ Capital, state only, 2,543 miles. 


\section{VALUATION AND PROFITS}

of their road and equipment to the Interstate Commerce Commission, and up to 1909, this cost, as reported for 221,679 miles of line, amounted to $\$ 13,451,451,401$, or $\$ 60,679$ a mile as compared with a net capitalization of $\$ 13,711,867,733$ for the entire mileage of the country, or $\$ 59,259$ a mile. Valuations have been made in a number of states; and in Washington, South Dakota, Michigan, Minnesota and Wisconsin, where the aggregate gross capitalization was $\$ 1,210,999,033$, the aggregate estimate of the cost of reproduction, new, of the mere physical properties made by the state commissions was $\$ 1,211,806,522$.

The only one of these valuations that has been put directly to the test of a court decision is that in Minnesota. The capitalization of the railways in Minnesota, excluding duplications due to intercorporate ownership of securities, was $\$ 39,496$ a mile; the commission's estimate of cost of reproduction, new, was $\$ 54,201$ a mile, or 38 per cent. greater. And, despite the fact that the commission's estimate of the cost of reproduction, new, was 38 per cent. greater than the capitalization, Judge Sanborn held in the Minnesota rate case that it was 20 per cent. too low as to the Northern Pacific, the Great Northern and the Minneapolis $\&$ St. Louis, the roads directly involved in the Minnesota litigation. The aggregate capitalization of these three roads in Minnesota was $\$ 155$,051,909 ; the commission's estimate of their cost of 
reproduction was $\$ 193,094,302$; and the valuation put on them by the court was $\$ 250,238,300$. If Judge Sanborn's decision be correct, then not only the Minnesota valuation, but all the other valuations made have been too low.

In view of all these facts, there seems ground for the confidence railway men express that an estimate of the cost of reproducing the physical properties of the railways of the United States would equal, and probably greatly exceed, their outstanding capitalization. The demand for valuation was started as a means of reducing rates. Those who started it had no conception of the additions to the values of American railways that have been made by the investment of earnings in permanent improvements and by increases in the value of real estate. Of course, if a valuation largely exceeded the capitalization of the railways, instead of legally justifying reductions in rates, it would legally justify substantial advances in them.

Even if it did so it might be commercially impracticable for the roads to take full advantage of it. It is very widely believed that the railways are not only overcapitalized, but that they have so adjusted their rates as to pay a return on their capitalization. This is a misapprehension. In some periods many have not paid the interest on their bonds, and have become bankrupt. Never have all paid dividends on all their stock. In the three years 1895-1897 inclusive they paid no divi- 
dends on over 70 per cent. of it. Not until as recently as 1901 did they pay dividends on 50 per cent. of it. Even in 1907, their most prosperous year, they paid none on 33 per cent. of it. Of course, if they based their rates on their capitalization, they would have so fixed them as to have made them yield a return on this part of their stock. They have had to make rates which the traffic would bear, and with which they could meet the competition of each other and of the water carriers. Thus conditioned, they have been unable so to adjust them as to earn a return on their aggregate capitalization-however much they may have longed to do so. They would be confronted with similar conditions after a valuation was made. The rates on each commodity and for each haul would have to be adjusted as they have been in the past-that is, with reference to what each kind of traffic, according to its value and the competitive conditions under which it was handled, could and would bear-and if the aggregate valuation of the railways, like their aggregate capitalization in the past, were such that the rates could not be so adjusted as to earn a return on all of it, the roads would have to be content without a return on parts of it.

It is not meant to imply that no advances would be practicable, but merely that no very great advances might be practicable. No doubt considerable advances on some commodities could and 
would be made. But it must be borne in mind that if rates were to be based on valuation, and valuation were to be based on the cost of reproduction of the properties, then every increase in the value of the real estate owned by the railways would entitle their owners to a larger minimum return. If rates were raised accordingly, a crushing burden might ultimately be imposed on the commerce and industry of the United States. The effect would be to hamper their development; which would react with great and harmful force on the earnings of the railways. ${ }^{1}$

One reason, no doubt, why valuation has been received with such widespread favor as a possible solution of the problem of determining the reasonableness of railway rates is that in many cases it has served pretty well as a basis for the regulation

"At first it was the popular advocate, the shrewd politician, who seized upon physical valuation as a slogan because he had heard so much of watered securities that he believed that a valuation of ralway property would afford an automatic excuse for the reduction of rates. But after the first few valuations had been made the shrewd politician dropped that theory like a hot putato. The practice of the mailways in the past of putting back into the property : large a proportion of their revenues through maintenance expenses, and the increment of real estate values which the railways claimed ecually with the owner of the corner int, were demonstrated to have run up the physical value of most of the railways, when ascertained by any fair system of appraisal, to a figure which was dangerous to the theo: that rates were too high if based solely on physical value. 
of the rates of other public utilities. But a railway differs from most other public utilities in several important particulars. It owns a large amount of real estate, while such public utilities as street railways, light and power companies and water works occupy, in the main, real estate owned by the public. An appraisal of one of these utilities is, therefore, much simpler and easier than a physical appraisal of a railroad. A public utility, such as a street railway or a water works, handles only one kind of business. A railway handles a great many different kinds of traffic which cannot bear the same rates. A public utility, such as a street railway or a water works, usually has a monopoly in its field, while steam railways operate under varying physical conditions, have widely varying amounts of traffic, and, despite the fact of these differences in conditions,

So some railways themselves who at first had opposed physical valuation, seized upon the discard of the politician and promoted it into a ground for an injunction. But probably this plea must now be abandoned also by the railways. The implacable logic of the suggestion that on this theory as values are constantly increasing, rates must also constantly increase, would seem to put an end to ratemaking on the simple arithmetic of physical valuation, for every student of political economy knows that railway rates in the United States, taken by and large, have, through the operation of general economic laws, gradually and steadily decreased." - From an address by Fairfax Harrison, President Chicago, Indianapolis \& Louisville Railway, before the Transportation Club of Indianapolis, March 31, 1911. 
compete with each other and with water carriers at numerous points, and must make their rates with reference to these competitive conditions. Therefore, while making and regulating the rates of a street railway or a water works is a comparatively simple matter, involving comparatively few and simple considerations, the making and regulating of the rates of a steam railway, which apply to the carriage of passengers and of from six to ten thousand different commodities handled under widely varying conditions, is a highly complex matter. The earnings of a public utility, such as a street railway or a water works, do not fluctuate greatly. In the calendar year 1908 the gross earnings of the railways of the United States declined $\$ 300,000,000$, while those of the street railways increased.

While, therefore, something like mathematical exactitude is practicable in the regulation of other utilities it does not seem practicable in the regulation of railways. The making and regulation of railway rates-so long, at least, as they are owned by different companies-must always be, not. merely an exercise in mathematics, but an exercise of judgment guided by a thorough knowledge of economic principles and commercial and transportation conditions.

It may be advisable, as a matter of public policy, to ascertain the probable cost of reproducing the physical properties of the railways. This would 


\section{VALUATION AND PROFITS}

satisfy the public as to whether or not they are earning excessive returns. But whether a valuation be made or not, we must continue to determine the reasonableness of specific rates precisely as railway men and intelligent railway regulating authorities have heretofore; and it might be wiser, instead of making a valuation and using it as a measure of the reasonableness of rates as a whole, whether those of one road or of all the roads of the country, to judge of the reasonableness of entire schedules of rates in the future, as economists have in the past-that is, by noting their effects on the movement and growth of traffic; by comparing them, making allowances for differences of conditions, with the rates on other railways in this and other countries; by comparing the capitalizations of the railways whose rates may be in question-allowances again being made for differences in conditions-with the capitalizations of other railways in this and other countries; and by comparing their returns with the returns earned by other railways similarly situated, and in other industries. If, in view of these considerations, the rates of a railway, or a group of railways, seem unreasonably high, perhaps they should be reduced; and if they seem unreasonably low, perhaps they should be allowed to be advanced.

Personally, it seems to me that very exaggerated prominence has been given in recent years to 
the question of the basis on which rates as a whole should be regulated. I believe this for two reasons. First, all my comparisons of rates in this and other countries have led to the conclusion that rates here, on the average, are relatively low. Second, as I have pointed out, the determination of what profits the railways shall be allowed to earn is apt to have comparatively little influence in determining how high or how low their rates shall be. The dividends on their stock amounted in 1910 to but 16 per cent. of their operating expenses. It is, therefore, from the standpoint of those who pay the rates, almost seven times as important that, by efficient and economical management, their operating expenses shall be kept down as that their dividends shall be kept down.

The great desideratum is the working out of some permanent policy which will tend to secure to the public the best practicable service at the lowest rates practicable for such service. This end is much less apt to be attained by a policy of restrictive regulation which will tend to keep the railways and the people at loggerheads than by a policy of coöperative regulation-that is, by some policy which will give the railways an incentive to good management and will cause the results of their good management to be equitably divided between the people and their owners. The railway managers have more to gain for the owners by following a course that tends to promote the 120 
interests of both the owners and the public than by following one that tends to promote the interest of the owners at the expense of the public. Similarly, the public has more to gain by adopting a policy that will tend to benefit both the owners of the railways and the public than by adopting one designed to promote the interests of the public at the expense of the owners.

Conditions may change, but for the present it would seem that the best course for the public to take is to cause public authorities to so regulate rates as to establish equitable relations between them; to exercise some control over the issuance of railway securities mainly to see that none in future are issued except for cash or its equivalent, and that the money derived from them is honestly invested in the properties; and then to let each railway earn such return as it can, so long as the average return of any particular group of railways, or of the railways as a whole, does not exceed the ordinary rate of commercial return in the territories where they do business. Under this plan some railways would earn very large returns on their capitalizations; but if other railways operating in the same territory and charging the same rates were barely able to earn only the current rate of interest on as low or lower capitalizations, this would be strong evidence that the prosperity of the more prosperous roads resulted largely from better management; that they were 
entitled to their larger returns; and that it was expedient for the public to let them enjoy them. This scheme of regulation does not appeal so strongly to minds loving mathematical exactitude as does the plan of making a valuation and fixing the precise percentage of profit on it that each railway shall be allowed to earn; but it is more feasible and better adapted to secure to the public in the long run low and equitable rates and good service.

NotE. - While the proofs of the text were being read the report of the Railroad Securities Commission to President Taft was made public. This Commission was created to study and report on the question of regulation of railway securities by the federal government. It included within the scope of its investigation the matters of valuation and limitation of profits. The reasoning in its report and the conclusions reached are very similar to those in the text. The Commission was composed of Arthur T. Hadley, President of Yale University; Frederick N. Judson, a distinguished lawyer and author of "Judson on Interstate Commerce"; Frederick Strauss, a member of a great private banking firm; Walter L. Fisher, Secretary of the Interior; and Balthasar H. Meyer, a member of the Interstate Commerce Commission. The Securities Commission favored giving the Interstate Commerce Commission "broad powers and adequate means for valuation of the physical property of railroads as one element in determining fair value, whenever, in the judgment of that Commission, this is of sufficient importance to warrant such action. . . . The attempt to oppose a system of physical valuation of this kind tends to give countenance to exaggerated estimates of the amount of water in railroad stocks." "It is hardly necessary to add," the Commission said, "that your Commission does not believe that the cost of reproduction of the physical 


\section{VALUATION AND PROFITS}

properties, however carefully computed, is the sole element to be considered in determining the present value of a railroad, or that the outstanding securities could or should be made to conform to any such arbitrary standard."

In another place the Commission said: "No attempt should be made by statute to limit railroad profits to a fixed percentage, or to treat a high cash dividend as necessarily indicating extortion. Railroad charges must be reasonable; but to try to control rates by arbitrarily limiting profits is to put the manager who makes his profit by efficiency and economy on the same level as the one who tries to accomplish the same result through extortionate charges. . . . We hear much about a reasonable returu on capital. A reasonable return is one which under honest accounting and responsible management will attract the amount of investors' money needed for the development of our railroad facilities. More than this is an unnecessary public burden. Less than this means a check to railroad construction and to the development of traffic. Where the investment is secure, a reasonable return is a rate which approximates the rate of interest which prevails in other lines of industry. Where the future is uncertain the investor demands, and is justified in demanding, a chance of added profit to compensate for his risk. We cannot secure the immense amount of capital needed unless we make profits and risks commensurate. If rates are going to be reduced whenever dividends exceed current rates of interest, investors will seek other fields where the hazard is less or the opportunity greater. In no event can we expect railroads to be developed merely to pay their owners such a return as they could have obtained by the purchase of investment securities which do not involve the hazards of construction or the risks of operation." 


\section{CHAPTER VII}

\section{RAILWAY EFFICIENCY FROM THE STANDPOINT OF ECONOMY}

THE public is always concerned as to the effciency with which our railways are operated. The railway system of the United States is the greatest in point of mileage, of investment represented, and of traffic handled in the world. That public sentiment in this country is still opposed to public ownership is due to the fact that it is believed that government ownership might endanger our political institutions and that private management of this great railway system is more efficient than public management would be. If it should be shown that under private ownership the operation of our railways is relatively inefficient, either as compared with what it ought to be, or as compared with that of railways in other countries which are owned and operated by the state, this would be a strong reason for a change in public sentiment regarding the best railway policy for us to follow. ${ }^{1}$ For inefficient management makes

Public interest in the question of the efficiency with which railway transportation in the United States is conlucted has been greatly intensified recently by testimony introduced at the hearings before the Interstate Commerce 
operation needlessly expensive; and, in the long run, whatever tends to increase the cost of operation tends to increase the rates that the public must pay for the transportation service.

Any intelligent consideration of the question as to whether any railway or group of railways is efficiently managed must be preceded by definition of what is meant by "efficiency." The word is quite commonly used in discussions of railway affairs as if it were synonymous with "economy." But economy is not the same thing as efficiency. The public demands, and properly, that the railways shall not only be economically operated, but that they shall give good service. Efficient operation may, therefore, properly be defined as the rendering, as economically as may be practicable in the circumstances, of such service as best furthers the public convenience and welfare.

The railway managers have reached pretty accurate conclusions as to the most economical speed to run any given train with an engine of any given tractive power. But this most economical speed may be so slow as to be inefficient for shippers

Commission in 1910 in the so-called "rate advance" cases to show that they might be operated with much greater efficiency. Mr. Louis D. Brandeis, a prominent Boston lawyer who was counsel for some of the shippers in these cases, asserted that by the adoption of so-called "scientific management" the roads could save a million dollars a day, and a number of professional efficiency engineers gave evidence in support of this view. 
who wish their goods rapidly transported to their destination. Mere economy may be hauling cars loaded to their maximum capacity and running trains with enough cars to utilize the engine's full tractive power. But good service is incompatible with holding cars and trains at terminals until each can be loaded to its capacity. The commercial organizations in several cities, including New York, Pittsburgh, Chicago and St. Louis, have within recent years got the railways to put on many "package cars" which run from these cities to numerous points over a wide area on regular schedules. When the time comes for one of them to go it must start whether it contains 40,000 pounds of merchandise or 4,000 pounds. Therefore, their average lading is small. From the standpoint merely of economy this is inefficient operation; but the shipper considers it efficient operation, because it is good service.

Similarly, in the passenger service economical operation would consist of loading each car to its reasonable capacity and running just enough wellloaded trains to handle the available business. But true efficiency of operation involves such frequent train service that the average number of passengers hauled per train in the United States in the year ending June 30,1909 , was only 54 , or less than enough to fill an average day coach.

If one is disposed to question whether speed and safety are, from the standpoint of the public, as 
important elements in efficiency of operation as economy let him consider what is taking place daily on our railways. They have over 2,135,000 freight cars. Perhaps one-half of these are always under load. The average value of their loads is perhaps $\$ 500 .^{1}$ There is, then, at any given time about $\$ 530,000,000$ worth of goods in transit. The average rate of commercial profit in this country is perhaps 12 per cent., and 12 per cent. on goods of this amount is over $\$ 60,000,000$ a year. The more speedily these goods are moved the smaller is the economic loss on them from their being kept unavailable for use, sale or consumption. Nor is this all. The manufacturer need keep on hand smaller quantities of raw materials, and the jobber and retail merchant smaller stocks of goods if each knows that when he places an order he can rely on the railway to bring it to him within a time both short and certain. To whatever extent speedy and dependable transportation releases capital that otherwise must be kept tied up in goods in transit, in manufacturers' raw materials and in jobbers' and retailers' stocks, to that extent it increases the amount of capital available for other uses.

We commonly think of safety in operation as of importance only in the passenger service. This is

1 "Railway Corporations as Public Servants," by Henry S. Haines, page 154. 
far from true. The railways of the United States pay out annually about $\$ 30,000,000$ for loss of and damage to property. This is economic waste, a large part of which can be eliminated only by increasing the safety of operation.

Of course, however, those most interested in safe operation are not the shippers. There are on the pay rolls of the railways of the United States almost 1,700,000 men. The number of passengers transported by them in the fiscal year 1910 was $971,683,199$. On the average every inhabitant takes over ten railway trips a year, riding a total distance of about 350 miles. Regarding the matter from a purely economic standpoint, enormous waste was occasioned by the unsafety of operation which resulted in 3,602 employees and 356 passengers being killed in the fiscal year 1911, and in 126,039 employees and 13,433 passengers being injured. Still further economic waste was caused by 6,438 other persons being killed and 10,687 others being injured, a total of 10,396 killed and 150,159 injured. ${ }^{1}$ We want economical operation. We want low rates. But they are of little importance compared with the increased efficiency needed to make transportation safe, almost regardless of what attaining this end would cost.

Bearing in mind, then, that railway efficiency

${ }^{1}$ For details regarding the causes of railway accidents see page 166 . 
consists, first, of economical construction and working, and, second, of the rendering of good service, let us consider some facts indicating how efficiently our railways are operated and what ought to be done to increase their efficiency.

Have they been produced in their present condition economically? The cost of road and equipment up to June 30, 1909, of railways having 221,679 miles of line was, according to their reports to the Interstate Commerce Commission, $\$ 60,679$ a mile. The average capitalization of all the roads in the country was $\$ 59,259$ a mile. It is quite generally believed that they are overcapitalized. This is due to the known facts that in their earlier history many were overcapitalized and that the stock of some has been freely watered since. But, considering them as a single system, the water probably has all been absorbed by increases in the value of their real estate and by the making of permanent improvements from earnings without capitalizing them. Probably to have constructed them and put them in their present condition by an aggregate expenditure equal only to their outstanding capitalization, if every expenditure for capital account, and only expenditures for capital account had been charged to capital account, would have required rigid economy. The fact that the capitalization of our railways is less than that of the railways of any other first-class country supports this view. The railways of the United 
Kingdom are privately owned. Most of those of France are privately owned. Practically all of those of Germany and Switzerland are owned by the governments. The capitalizations (or costs of construction) per mile of the railways of these countries compare with that of our railways as follows: ${ }^{1}$ United Kingdom, $\$ 275,040$; France, $\$ 139$,237 ; Switzerland, $\$ 110,740$; Germany, $\$ 109,788$; United States, \$59,259.

American railways have not paid as much for land for right of way as have those of Europe. But they have paid more for the labor used in construction. They have not so many miles of second, third and fourth tracks and yards and sidings as some European railways; but their capitalization per mile of track, as well as per mile of line, is much less than that of any foreign railways with which it is fair to compare them. For example, the capitalization per mile of track of the railways of the United Kingdom is $\$ 118,000$; of the Prussian-Hessian railways, $\$ 76,217$; and of the railways of the United States, $\$ 40,052$.

In comparing the relative capitalizations (or costs of construction) of American and foreign railways one pertinent fact is often overlooked. This is that the European railways were built

${ }^{1}$ The figures are for the following years: United States, 1909; United Kingdom and Germany, 1908; France and Switzerland, 1907. 
through settled countries that could afford them a large trafic from the beginning and were, therefore, originally very substantially constructed, while those of the United States usually have been originally built through thinly populated territory where the traffic immediately available has been small. In consequence, they have been at first very cheaply constructed; and then, when increased business has justified, have been partially or wholly reconstructed in order to reduce grades and curvature, and to shorten their lines. The original right of way has in many cases been entirely abandoned for many miles. This method of developing our railroads has been suited to the peculiar conditions of this country; but obviously it has tended in the long run to enlarge, rather than to restrict the cost of construction and the resulting capitalization. The railways of New South Wales have been built by the government. They were constructed under conditions similar to those of pioneer days in the United States. They are physically much inferior to our railways. Yet their cost of construction has been $\$ 64,000$ per mile. ${ }^{1}$

As I have already shown in the chapters on "Railway Valuation and Profits," the valuations

${ }^{1}$ I have given the capitalizations per mile of the railways of a number of countries in one of the chapters on "Railway Valuation and Profits." 
of railways that have been male by the various state commissions and courts tend to show that our railways could not now be reproduced for an amount equal to their capitalization. The conchusion is hard to escape that, however it may have been in individual cases, comparative economy has been used in the development of our railways as a whole.

In considering whether any railway, or number of railways, is operated with reasonable economy we should not fix our attention on any part or parts of them, as, for example, their shops or their station service. We should consider the results of their entire operations. For the railway is a complexus of numerous industries and professions. None of its parts can with exact justice be compared with similar concerns not connected with the transportation business. It might be shown, for example, that the cost per unit of doing many different kinds of work in a railway's shop exceeds the cost per unit of doing the same kind of work in factories engaged in purely commercial business. But this would not prove that the shops of the railways are inefficiently managed. When business gets dull the manager of a factory may close down entirely until enough orders accumulate to enable him to resume operations on a scale on which he can turn out each unit of product economically. But the railway must operate its trains continuously, whether traffic is light or heavy; the 
capacity of its shops should be the maximum that the maximum business may require; and, therefore, they will, necessarily, when business is light, be operated with relative want of economy. The agents at a good many country stations have only enough work to keep them busy part of the day. Proper service to the public requires that they be kept on duty throughout the day. To train them to do their work in one-third less time would, therefore, be merely to give them more hours of idleness, which would not measurably increase the economy of operation!

But while the economy with which a railway is managed can be judged only by its entire results, it is exceedingly difficult, owing to the great differences between the conditions under which railways are operated, to devise any standards for measuring the comparative economy of their management. The business of railways is that of producing transportation for the public. The units of their service are one passenger hauled one mile and one ton hauled one mile-the "passenger" mile" and the "ton mile." The expenditures that they make to produce passenger miles and ton miles are of two classes. These are (1) the fixed investment in their plants, represented more or less accurately by their capitalization; and (2) their operating expenses. If we had two roads built and operated under precisely similar conditions, and handling the same kind and amounts of 
traflic, the number of passenger miles and ton miles that they prociuced for each dollar of investment and each dollar of operating expenses would be a very satisfactory test of the economy with which they were constructed and are operated. But the conditions required for such exact and satisfactory comparisons of the results secured by different companies can seldom be found.

Take, for example, the railways between whose capitalizations I have made comparison-those of the United Kingdom, Germany, France, Switzerland, and the United States. As I have said elsewhere, the railways of the United Kingdom collect at, and deliver from, their stations much of the freight they transport. The railways, both of the United Kingdom and of other countries of Europe, themselves handle the business which in this country is handled by express companies. The average distances that freight and passengers are hauled there are much less than they are in the United States.' The density of passenger traffic - that is, the number of passengers hauled one mile per mile of line per year-is much greater in

${ }^{1}$ The average hauls of freight are as follows: United Kingdom (estimated), 25 miles; Switzerland, 70 miles; France, 80 miles: Germany, 85 miles; United States, typical haul of the average railway, 141.87 miles, typical haul of all railways regarded as a system, 251.1 miles. The average journeys of passenger's are as follows: United Kinglom (estimated), 7.8 miles; Switzerland, 12.8 miles; Germany, 14.31 
Europe than in the United States. On the other hand, the density of freight traffic-that is, the number of tons hauled one mile per mile of line per year-is greater in the United States than in most of the countries of Europe and very much greater than in many of them. Now, while either a dense passenger traffic or a dense freight traffic may be handled more economically per unit than a light one, freight traffic is much more susceptible to the introduction of economies of operation than is passenger traffic. All these conditions tend to make it practicable for the railways of the United States to render more units of public service per dollar of capital and of operating expenses than can those of Europe. On the other hand, the prices of materials and equipment are as high here as, or higher than, in Europe, and the wages of labor are fully twice as great. On the whole, the American railways have enjoyed more favorable conditions for economical operation, and the statistics bearing on the subject disclose that they have taken advantage of them to a very marked degree.

miles; France, 20.75 miles; United States, 32.85 miles. The average journey of first-class passengers in Europe, who are charged rates as high on the average as those in the United States, is longer than the average journey in the United States. On the Prussian-Hessian railways, the average journey for first-class passengers in 1908 was 79.17 miles, and in France it was 40.5 miles. 


\section{THF AMERICAN TRANSIORTATION QUESTION}

The following talule shows in detail the relation between capitalization, operating expenses and public service rendered:

Ton miles per mile of road

Passenger miles per mile of road....

Total units of public service per mile of road................

Capitalization (or eost of construc- $\}$ tion) per mile of road ..........

Ton miles per dollar of cupital.....

Passenger miles per dollar of eapital

Total units of rublic service per? dollar of capital ..............

Operating expenses per mile of roul Ton miles per dollar of operating ? expenses ...................

Passenger miles per dollar of operating expenses ..............

Total units of publie service per? dollar of operating expeuses...

\begin{tabular}{|c|c|c|c|c|}
\hline $\begin{array}{l}\text { United } \\
\text { States. }\end{array}$ & $\begin{array}{l}\text { Uniterl } \\
\text { King:- } \\
\text { lom. }\end{array}$ & Germany. & France. & $\begin{array}{l}\text { Switz- } \\
\text { esfindel. }\end{array}$ \\
\hline 1909 & 1908 & 1908 & 1907 & 1907 \\
\hline $\begin{array}{l}953,986 \\
127,299\end{array}$ & $\begin{array}{l}529,622 \\
580,041\end{array}$ & $\begin{array}{l}827,400 \\
540,045\end{array}$ & $49 \%, 939$ & $\begin{array}{l}4.12 .012 \\
45,651\end{array}$ \\
\hline $1,081,285$ & $1,109,666$ & $1,367,445$ & $877,29 \cdot]$ & 893,666 \\
\hline$\$ 59,259$ & $\$ 275,040$ & $\$ 109,788$ & 8139,207 & $\$ 110,740$ \\
\hline $\begin{array}{r}16.09 \\
2.14\end{array}$ & $\begin{array}{l}1.92 \\
2.11\end{array}$ & $\begin{array}{l}7.54 \\
4.92\end{array}$ & $\begin{array}{l}3.5 \pi \\
2.73\end{array}$ & $\begin{array}{l}4.09 \\
4.18\end{array}$ \\
\hline 18.23 & 4.03 & 12.46 & $(6.30)$ & 8.24 \\
\hline 80,851 & $\$ 16,036$ & $\$ 13,394$ & $\$ 7,352$ & 89,603 \\
\hline 139 & 33 & 62 & 67 & 46 \\
\hline 14 & 36 & 40 & 51 & 48 \\
\hline 158 & 69 & 102 & 118 & 94 \\
\hline
\end{tabular}

The above table shows that in proportion to capitalization the railways of the United States handle 1.47 per cent. more passenger traffic than those of the United Kingdom, 56.50 per cent. less than those of Germany, 21.61 per cent. less

'Attention should here be called to the fact that railway statisties are very incompletely compiled in the United Kingrom, and that such figures as the average passenger haul, the average freight haul, the average revenue per ton and per passenger per mile can be estimated only after rather olatorate investigation, and that even then any statements of these averages cannot be made more than approximately correct. The figures here given are those that are aecepted by the best authorities as most nearly correct. 


\section{EFFICIENCY AND ECONOMY}

than those of France, and 41.81 per cent. less than those of Switzerland. On the other hand, in proportion to capitalization, they handle $738.02 \mathrm{per}$ cent. more freight than those of the United Kingdom, 113.39 per cent. more than those of Germany, 350.70 per cent. more than those of France, and 296.30 per cent. more than those of Switzerland. In proportion to their operating expenses they handle 47.22 per cent. less passenger traffic than do the railways of the United Kingdom, 52.5 per cent. less than those of Germany, 62.74 per cent. less than those of France, and 60.41 per cent. less than those of Switzerland. On the other hand, in proportion to their operating expenses, they handle 321.21 per cent. more freight than those of the United Kingdom, 124.19 per cent. more than those of Germany, 107.46 per cent. more than those of France, and 202.17 per cent. more than those of Switzerland. ${ }^{1}$ Now, while unquestionably the difference between the results got from each dollar of investment and each dollar spent for operation here and abroad can be largely accounted for by differences in conditions, it cannot by any means be wholly so accounted for. It is very largely due to the superior courage, enterprise and skill with which the railway managers of the United States have so developed the facilities of their lines as to

${ }^{1}$ As I have shown elsewhere, the average passenger rate in European countries is somewhat lower, and the average freight rate very much higher than in the United States. 
make economical operation practicable. ${ }^{1}$ The caparity of freight cars in Europe is usually from 10 to 15 tons. The average probably does not exceed 12s tons; and there has been but a small increase in many years. In the United States the average capacity in 1909 was 35 tons, an increase of 25 per cent. over that of 1902 . The differences between the tractive powers of locomotives, and between the sizes of the car loads and train loads in which traffic is handled, in Europe and the United States, correspond to the difference in the capacities of

${ }^{1}$ In an article entitled "The Position of British Railways," in the North American Review" for November, 1909, W. M. Acworth, the leading English authority on railway economics, said: "If an outsider might criticise, I should say that I am startled at the ingratitude which the American public has displayed in return for the marvelous skill and energy with which American railway men revolutionized the speration of American railways in the years when traffic began to recover after the panic of 1893 . New capital being practically unobtainable, they made one dollar do the work of two, and turned out with the old plant an output that would have been inconceivable to the same men ten years before. Regarding the matter from an operating side, American railways have had enormous difficulties to face, and on the whole have surmounted them. . . U Undoubtedly, British railways have had great difficulties to face. With a revenue increasing but slowly. they have had to meet the demands, constantly more exacting, of the public and the legislature. But I am bound to say that the conditions they have had to face have not been as difficult as those that have been faced successfully in America. The British legislature has interfered to require shorter hours of labor, larger expenditure on safety appliances, and in some cases even lower rates. But the sum total of it all has not been 
freight cars. The average tractive power of locomotives in the United States in 1902 was 20,485 pounds. In 1909 it was 26,601 pounds, an increase of 30 per cent. ${ }^{1}$

The number of passengers hauled one mile per passenger locomotive increased between 1889 and 1900 from $1,474,765$ to $2,185,877$, or 49 per cent. The number of passengers hauled one mile per passenger car increased from 431,059 to 638,586 , or 48 per cent. The tons of freight hauled one mile per freight locomotive increased from 5,966,-

very serious, and I think an American railroad official would breathe a sigh of content if he could exchange the whips of Louisiana or the scorpions of Texas for the gentle parental suasion of the British Parliament. Wages on British railways have gone up and hours of labor have gone down. The same thing has happened in the States. But in the States organization has enabled one man to do the work of two, with the result that, per ton handled, wages are down, not up. That result has, unfortunately, not been attained in Great Britain."

${ }^{1}$ There are no statistics regarding car capacity and locomotive tractive power for the railways of the United States earlier than for the year 1902. Mr. J. Kruttschnitt, Director of Maintenance and Operation of the Union Pacific Railroad and the Southern Pacific Company, in a lecture to the students of Harvard University, on April 26, 1911, gave much earlier figures for the Southern Pacific Company. They showed that the average capacity of freight cars on its lines increased from 18.5 in 1889 to 37.6 in 1909 , or 102 per cent. ; that the average driver weight of locomotives increased during the same period from 27 to 58.8 tons, or 117.77 per cent., and that the average tons of dead weight per ton of car carrying capacity decreased from .60 to 1.43 , or 38 per cent. 
1933 to $6.447,708$, or 8 per cent., and the tons hauled one mile per freight car increased from 95,458 to 105,518 , or 11 per cent. The ton miles and passenger miles moved per employce, largely in consequence of improvements such as these, increased from 113,915 in 1889 to 148,837 in 1899 , and to 164,946 in 1909, an increase for the latter year over 18s!) of 45 per cent.

Meantime, innumerable other improvements were made tending to increase the economy of operation, such as reductions of grades, eliminations of curvature, the laying of heavier rail, strengthening of bridges and other structures, building of more main tracks, side tracks, yards and terminals, adopting of more refined methods of operation, such as carefully regulating locomotives, running them at the most economical speeds for the train loads they haul, etc. The average tons per train increased in the ten years from 1899 to 1909 from 244 to 363 , or 49 per cent. ${ }^{1}$ The average freight train load in Europe is certainly not more than one-half of what it is in this country. From a study of the meager data available, I believe that in England it is not more than one-third. Of course, the larger car loads and train loads are,

' Meantime, the average number of passengers per train insieased only from 41 to 54 , or 32 per cent., although the percertage of increase in the density of passenger traffic was greater than in the density of freight traffic. This shows how much more susceptible to the introduction of economies of handling freight traffic is than passenger traffic. 


\section{EFFICIENCY AND ECONOMY}

the more economically, other things being equal, traffic can be handled. ${ }^{1}$

\section{W. M. Acworth ${ }^{2}$ is the leading authority on}

${ }^{1}$ Perhaps the tendency to take advantage of improvements in roadway and rolling stock to increase the train load can be best illustrated by some striking examples, all of them afforded by the year 1909. The New York Central hauled with a Consolidation locomotive a train consisting of 105 cars of coal, the gross weight of the train-including both freight and dead weight-being 7,381 tons. The Lake Shore a little later, with a Consolidation engine, hauled a train load of ore containing 100 steel cars and having a gross weight of 7,433 tons, from Ashtabula, Ohio, to Youngstown, a distance of 65 miles, in 5 hours and 15 minutes. On the Pennsylvania Railroad a Consolidation engine pulled a train composed of 105 steel cars, which contained 5,544 tons of coal, from Altoona, Pennsylvania, to Enola, a distance of 127 miles, at an average speed of 17.6 miles per hour. The train was 3,600 feet long, or a little more than two-thirds of a mile. The steepest grade met was 12 feet to the mile. On the Virginian Railway a Mikado engine hauled 100 steel cars, containing 5,500 tons of coal, 125 miles in 8 hours. The engine was 73 feet 8 inches long. The cars were 43 feet over couplers and the caboose, which weighed 18 tons, was 30 feet long. The weight of the train behind the engine was 7,562 tons. The grade on which it was hauled was easy, but there was some opposing grade. Later a Mallet engine hauled on the Virginian a train composed of 120 steel cars, which, with the engine and caboose, was 6,286 feet long, or 6 feet more than a mile. The weight of the coal in the train was 6,000 tons, or $12,000,000$ pounds. In such trains as these the cost of hauling one ton of freight one mile seems reduced close to the practicable minimum. Perhaps, however, a few years will see developments by which the cost can be made still less.

2Author of "Elements of Railway Economics," "The Railways and the Traders," etc. 
transportation in England. He has studied railways and their operations extensively and is probably as competent to judge of their relative efficiency as any other man. In a recent newspaper. interview, 'given as he was starting to England after two months in this country, Mr. Acworth said:

It has always been my opinion that in actual economy of operation the railways of the United States are the first in the world. In the number of tons per car, cars per train; in the fullest utilization of locomotives; in the obtaining of the greatest measure of result for each unit of expenditure, they are not equaled by the railways of any other nation. When the Greek commanders after the battle of Salamis voted who should receive the prize for valor each put his name first, but all put the name of Themistocles second. And Themistocles received the prize. So, too, though German, French and English railway men would, I dare say, all put their own railways first in efficiency, they would all, I am sure, put yours second, and on the voting of the experts your railways would come out first.

Mr. J. Kruttschnitt has pointed out ${ }^{2}$ that between 1894 and 1909, a period of fifteen years, the average wages of labor and prices of commodities

${ }^{1}$ New York Evening Sun, February 1, 1911.

${ }^{2}$ Lecture to the students of Harvard University, April $26,1911$. 
in the United States increased 32 per cent., as shown by bulletins of the United States Bureau of Labor. Meantime the average freight and passenger rates in the United States slightly declined, the average rate per ton per mile in 1894 being 8.6 mills and in 1909, 7.63 mills; the average rate per passenger per mile in 1894 being 1.986 cents, and in 1909, 1.982 cents. Mr. Kruttschnitt calculated that if railway rates had increased as much in proportion during this period as the prices of commodities and the wages of labor, the country's bill for transportation during the period would have averaged $\$ 1,300,000$ per day more than it actually did; that for the year 1909 it would have averaged $\$ 2,760,000$ per day more than it did; and that for the entire period it would have been $\$ 7,844,343$,000 more than it actually was. This is the reply of the railway managers to the statement which has been made that by more efficient management they could reduce the cost of transportation a million dollars a day. They say that these figures show that by efficient management in the past they actually have saved the country more than a million dollars a day; and that this shows they can do so in future if given a chance; but that they must be given a substantial amount of time and the coöperation of other interests in order to accomplish these results.

To say that our railways are operated with comparative economy is not equivalent to saying they 
ano operated as economically as they could be, or, perhaps, ought to be. There is constant complaint from railway officers that the efficiency of labor has not increased with its wages, but has declined. The Interstate Commerce Commission, in its opinion in the "rate advance" cases in the spring of 1911, intimated that the fact that the same men are dominant in the affairs of some concerns making and selling railway supplies and equipment and some railways, has caused railways to pay higher prices for some kinds of supplies and equipment than they would have paid in a market where all buyers and sellers dealt at arm's length. Ground is not entirely wanting for this charge. It can be shown that the amount of work done by engines and cars has not increased as much as their capacities. ${ }^{1}$ The efficiency of labor, the number of

${ }^{1}$ While the average tractive power of locomotives increased 30 per cent. between 1902 and 1909, the average number of passengers per train increased only 20 per cent., and the average number of tons per train only 22 per cent. The consequence was that the number of passengers hauled one mile per pound of tractive power decreased 25.6 per cent., and that the number of tons hauled one mile per pound of tractive power decreased 30 per cent. The average capacity of freight cars increased 25 per cent. between 1902 and 1909 and the average tons rnoved per car mile, including both empty and loaded cars, increased less than eight-tenths of 1 per cent., and the average tons moved per loaded car mile increased less than 3 per cent. The result was that the average number of tons moved one mile per ton of car capacity decreased 20 per cent. 
miles made by each car and locomotive daily, ${ }^{1}$ the tons hauled per car and locomotive, ought to be increased wherever this can be done without impairing the service. Probably the railway mana-

${ }^{1}$ The fact that on the average a freight car moves only 24 miles a day frequently has been cited as evidence that railways are inefficiently operated. But to say that because the railways on the average move a freight car only 24 miles a day they are inefficiently operated is like saying that because a man walks only 4 miles a day-when, in fact, he puts in only an hour a day at walking-he is a poor walker. The average speed of freight cars when in motion is not 24 miles a day, but about 10 miles an hour. The only way to form a correct opinion as to how efficiently freight car's are handled on the avelage is to consider in detail the average car's movement from the time it is started to be loaded until it has completed its trip and been unloaded. The average time required for the loaded and empty car movement involved in the average haul of freight in the United States is about 12 days, and the average distance the car moves about 330 miles. Two days' free time is usually allowed for loading and also for unloading (not including Sundays and holidays, for which additional free time is allowed) and the statistics of the demurrage bureaus show that the delays of the ear at terminals by the shipper and consignee for loading and unloading average about $4 \frac{1}{2}$ days for each movement. This leaves an average of $7 \frac{1}{2}$ days during which the car actually is in the possession of the railway and gives an average movement of about 44 miles per day. This time during which the ear is in the possession of the railway includes all legitimate detention of it, such as for switching in yards en route, for rigid inspection and frequent shoppings, and for occasional transfer of lading by reason of enforcement of the stringent safety appliance regulations. It includes the period during which cars are held for reconsignment to accommodate shippers, and also the periods during which cars are in shops; and, on the average, about: 
gers cannot effect these economies without the coöperation of employees, shippers and public authorities.

They must have the coöperation of shippers, be-

per cent. of the total number of cars are in the shops at any given time. It also includes the movement not merely of loaded cars, but also of empty cars; and, of course, the average movement of empty cars is much less than of loaded cars, because the empty car stands on the sidings for much longer periods, which periods of idleness are included in the average movement. The effect of a heavy reduction in traffic and consequent proportionate increase in the number of idle cars on the average movement of all freight cars was strikingly shown just after the panic of 1907. In October, 1907, when traffic was very heavy, the average movement of all the cars in the United States was 24.8 miles per day. In April, 1908, there were substantially 700,000 idle cars, including those in shops; and in that month the average movement per day was but 19.6 miles, or 20 per cent. less than in October, 1907. Now, there are four months in every year when practically all the freight cars in the country are busy, and eight months when a large part of them are not in service, and, of course, the great number of cars idle during these eight months pulls down the figure showing the average movement.

When all these conditions are taken into consideration it does not seem at all surprising that the average movement of a freight car is but 24 miles a day. It also appears perfectly evident that those who are best situated to increase this average movement are the shippers, who have actual yossession of the car for loading and unloading more than one-third of the time, who have practical possession of it for a considerable time for reconsignment, and whose failure to provide a more uniform traffic throughout the year makes it necessary for eight months of the year to have thousands of cars standing idle on the side tracks. 
cause without it they cannot secure such prompt loading and unloading of cars, and such large car loads and train loads, as are necessary to the most economical operation. They must have the coöpcration of the public authorities because, as I have sought to show in the chapters on "Railway Valuation and Profits," the adoption of a policy of restricting all railways to the same return would deaden enterprise and prevent the introduction of improvements in methods and plants. Another reason why they need the coöperation of the public and public authorities is to prevent legislation which increases the cost of operation without conferring any real benefit on any one. Of this class, for example, are the laws that have been passed in several states prescribing the number of men that must be employed in train crews. Ten or fifteen years ago two brakemen were sufficient for a freight train, although then the cars had to be coupled and the brakes applied by hand. There has been since then a very substantial increase in the tonnage hauled per train. This is partly because the number of cars per train has been increased, but it is also largely because cars of greater capacity are now used. In spite of the increased size of train loads there is not-owing to the fact that all engines have now been equipped with train brakes and all cars with automatic couplers - any more work for brakemen to do now than there was then. Nevertheless, the state 
laws referred to commonly require three brakemen on a train. The eflect of such legislation is to increase needlessly the number of men the railways must employ, and thereby raise the cost of transportation.'

Most important of all, the railways must have the coöperation of their employees; without it all efforts from whatever source to increase the economy of operation will be nullified. The wages annually paid by the railways of the United States now amount to over $\$ 1,000,000,000$. This is 60 per cent. of their total operating expenses. Unfortunately, the relations between the roads and many of their employees are not such-nor is there now any promise of their becoming such-as to promote the greatest reasonable economy in opera-

${ }^{1}$ A full crew bill was pending recently before the legislature of one of the Northwestern states. The management of one of the railways got one of its most experienced conductors to appear before the committee to which the measure had been referred, to oppose it. We will call his name Murphy. The following colloruy took place between the chairman of the committee and Mr. Murphy:

Chairman-Mr. Murphy, don't you think the passage of this bill would be beneficial?

Murphy-.. Yes, sir, I do.

Chairman-Will you please state to the committee what advantage would be derived from it?

Murphy Well, if you passed this bill there would be enough of us to get up a grood game of pitch back in the caboose.

This is, perhays, as sincere and convincing an argument for such legislation as ever has been made. 


\section{EFFICIENCY AND ECONOMY}

tion. Scientific management requires the training and compensating of each employee so as to get the maximum reasonable results, both in quantity and quality, from his labor. Where wage scales are wisely and fairly adjusted this means at once relatively high pay for the employee and a low unit cost of production for the employer. The leaders of the labor unions very generally oppose any scheme of wages under which one man doing a given kind of work is paid more than another man doing the same kind. One objection made by them to piece work and bonus wage systems is that after employers, by the use of such systems, have increased the average output per employee, they often have reduced the piece rate or the bonus, the consequence being that the employee has to do more work than before the introduction of the piece work or bonus system to earn the same pay. There is much ground for this complaint. Employers often have been guilty of this injustice. Another reason why labor unions often oppose schemes of wages designed to increase the work done by each man is their belief that this would tend to reduce the number of men employed.

Of course, every economist knows that this is a fallacy. The amount of work to be done in the world is not a fixed quantity. Work is done to produce things. The nominal wages of labor are money, but its real wages are not money, but what money buys. The things money buys are the 
products of labor. The less labor, as a whole produces, therefore, the less, in the long run, it tends to make its own wages-not its nominal, or money, wages, which by limitation of production may be actually increased, but its real wages-the products in which it is paid-which by the very same process are reduced. Therefore, by limiting the amount it produces labor is apt simply to bite off its own nose to spite the capitalist employer's face.

But while the antagonism of labor unions to any system of wages that tends to increase the amount of work done by each employee is unreasonable, it is very real; and nowhere is it more real, or more vigorously manifested, than on the railways. Railway train employees are paid on a sort of piecework basis. Under this scheme either ten hours' labor, or work on a train during the time that it moves 100 miles, is counted a day. If the employee works more than ten hours, or his train runs more than 100 miles, he is entitled to "overtime." He may run only 90 miles in 10 hours; if so, he has worked a day. He may run 110 miles in 3 hours; if so, he has worked 10 per cent. more than a day and is entitled to credit for a proportionate amount of "overtime." This wage system originally was adopted for the purpose, and no doubt had the effect, of expediting the movement of trains. But in consequence of the development of the railway business it has become an irrational and unduly 
expensive method of compensation. The wages of the employee should depend only to a limited extent on the speed of the machine he operates. They should depend mainly on results due to his own efforts. Now, under this system of paying railway trainmen, doubling the speed of a locomotive that pulled a train might double the wages paid to every man employed on it. The speed of engines and trains has been in very many cases greatly increased since this scheme of wages was adopted; and in consequence many employees are now earning very high wages for doing a comparatively small amount of work. For example, a locomotive engineer may make a three or four hour run out of Chicago, and then in a short time make the same run back, covering 200 miles in six or eight hours. He thereby earns two days' pay in this short time, not because he is a specially skilful workman, but because he has a fast train. Another just as good engineer may run another train over the same division the same day, and because he pulls a train that is scheduled slower may earn but half as much. A piece-work system that is based so largely upon what machines do, and to so very slight a degree upon what the men do who run them, is extravagant, and, as a means to stimulating individual effort, almost worthless.

But while the railway brotherhoods defend this system and would resist the substitution of some more equitable and economical one, they fight 


\section{THE AMERICAN TRANSPORTATION QUESTION}

every effort to introduce any method of fixing wages that is designed to reward each employee according to the quality and the quantity of the work that he does. The managers of the railways have introduced and retained piece work and bonus wage systems in various places. But before they could put the wages of all, or even of any considerable part, of their more than a million and a half workmen on an individual effort basis they probably would have to have and win a great strike. The public, before it criticises the railways for being less economically managed than they might be, should know these facts and look them squarely in the face. 


\section{CHAPTER VIII}

RAILWAY EFFICIENCY FROM THE STANDPOINT OF PUBLIC SERVICE

WE have now considered at some length the economy with which the railways of the United States are operated. In this respect they probably will bear comparison with any others. But, as has been pointed out, economy is not the sole measure of efficiency. Unfortunately, quality of service, unlike economy, is not susceptible of admeasurement and comparison in terms of comparative statistics. Furthermore, good service in one country may not be good service in another. It is the duty of railways to supply the kind of service the public demands and needs; and it may demand and need a different kind in one country from what it does in another. So the truest measure of the quality of the service in any country is not how it compares with that in others, but how it fills the requirements of the public served.

The traveler is most interested in the quality of the passenger-the shipper in the character of the freight--service. Travel ever has been deemed one of the principal diversions of leisure and chief 
means of culture. In our country of magnificent distances and intense commercial activity much of it is also necessary to the transaction of business. Under rather unfavorable conditions railway travel usually affords some pleasure; and under the most favorable conditions it has its pronounced discomforts. There are few ways in which we can add more to the pleasure and welfare of all than by increasing the convenience, comfort and speed, and ameliorating the inconvenience, discomforts and danger, of passenger transportation. Much has been done along this line; but there is yet much to do.

The typical railway station in the United States has been ugly, dark and dirty. Within recent years numerous fine and some truly magnificent stations have been built. Every one knows of the great Pennsylvania and New York Central terminals in New York City; of the Union terminals in Washington and St. Louis; of the Chicago \& Northwestern terminal in Chicago; of the Union terminal now under construction in Kansas City. The tendency to improve station architecture is not restricted to large cities; comfortable and attractive structures are being built at many towns and small cities. It is a tendency meriting emphatic and generous public encouragement. It does not increase railway efficiency from the standpoint of the owners of the railway. As much business can be done in a station costing 
$\$ 500,000$ as in one costing $\$ 5,000,000$. But it does increase efficiency from the standpoint of the public, for a commodious and beautiful station contributes to the comfort, delights the eye and improves the taste of all who use it. In every city and town, for both practical and esthetic reasons, the railway stations should be among the most sanitary, commodious and artistic buildings.

It is generally agreed that the best passenger trains in the United States are the best in the world. There are usually three classes of service on European railways. Theoretically, we usually have only one, except on certain railroads. In fact, however, on long runs we have three: first, that rendered on standard sleeping and parlor cars; second, that on tourist cars; and third, that on ordinary day coaches. For the last named only the regular fare is charged. For the others additional tourist car, or parlor, or sleeping car, rates must be paid. Mr. Edwin A. Pratt, ${ }^{1}$ an English writer, who has studied American railways, says that in proportion to the rates charged our ordinary day coach service is not as good as the third class service on English railways, but "comparing the ordinary American service, plus the charge for sleeper, with the English first class service, plus the charge for sleeper, the advantage is in favor of the former." On the other hand, Mr. Logan

1 “'American Railways," page 103. 
G. McPherson, ${ }^{\text {' }}$ one of the most intelligent American students of European transportation, says:

The accommodations provided for first and second class passengers on the European railways, are, as a rule, almost identical; a principal difference seems to be in the color of the upholstery; usually, however, there are fewer seats in the first-class carriages, so that the traveler has more elbowroom. The accommolations for third-class passengers are sometimes nearly as good as those for second-class, but generally they are much worse, so deficient in ordinary comfort that they would not be tolerated in the United States by any person able to buy a railway ticket. On the early morning and late evening trains that carry workingmen into and out of the large cities, the thirdclass cars have hard wooden benches upon which their occupants may be seen huddling together, each passenger supporting the person next to him as they smoke and sleep in the stifling atmosphere. There is no such rude equipment in the United States, not even in the trains in the mining and lumbering regions. ${ }^{2}$

The suburban dweller, or the farmer riding only 10 miles from his home to the nearest county seat

1 “'Transportation in Europe," page 89.

"Very low rates are made for workingmen's trains in England and on the Continent, and the traffic handled by them is very large. It is these rates which are paid for what $\mathrm{Mr}$. McPherson describes as very poor service and which largely draw the average passenger rate in Europe down to a level so much lower than the average passenger rate in this country. 
town, does not expect or need the comforts provided for those journeying from Chicago to the Pacific coast or from New York to Florida. Mr. McPherson indicates that the local service in Europe is poor. "On local trains and in the backward regions," he says, "the passenger service is an abomination." While we have some of the best suburban service in the world, it is hard for me to believe there is any local service in Europe that is worse than a good deal of the local service in the United States. The only excuse for the very wide difference between the kind of service given on our good through trains, and on most of our local trains, is that the traffic available for the latter is so small that even the most economical service is apt to be unprofitable. Of course, this, again, is largely explainable by the fact that the density of the passenger traffic of our railways is much less than that of most European railways, being about one-fifth that of the German and British railways and about one-fourth that of the French railways.

In point of frequency of passenger service none of our steam railways, outside of New England and a few other parts of the East, will compare with those of the leading countries of Europe. The passenger service in England is $2 \frac{1}{2}$ times as frequent as in New York, Pennsylvania, New Jersey, Delaware and Maryland, the region of the densest railway traffic in this country. It is de- 
sirable that passenger service shall be made as frequent as practicable; for frequent service contributes greatly to public convenience. Where the density of population is considerable increased service creates a large amount of new local business. Even where the rates of the electric interurban lines have been substantially as high as those of the steam roads the conveniency and frequency of their service have enabled them in many cases to take 75 to 90 per cent. of the local business from the steam roads, and to create a vast amount of new business.

Passenger service often could be made better with a reduced expenditure. Four different railways operate four trains daily each way between Chicago and St. Louis. Four times a day a quartette of trains departs and arrives at almost exactly the same time. Many of them run half empty. If half of the sixteen were taken off and the schedules of the rest were arranged so that they would arrive and depart at eight different hours the service rendered to the public would be improved, while the cost of rendering it would be reduced. But if the railways should enter into an agreement to take off part of the trains and start the rest at such hours as would better serve the public convenience they would be more apt to be criticised than commended for doing so- and might be prosecuted under the Sherman antitrust act for combining in restraint of trade! There 
are hardly two large cities in the country between which the service could not be improved, and at the same time its cost and the economic waste involved in rendering it reduced, by taking off some passenger trains and spacing the hours of departure and arrival of the rest farther apart. It is no advantage to the traveler for four trains to leave for his destination at the same hour; he can ride on only one at a time.

One of the chronic nuisances on American railways is the late passenger train. Its frequent causing of long waits at uncomfortable stations, and of the missing of train connections and business and social engagements, has been an important provocative of public irritation. It is not confined to sections where population is sparse and traffic small. One of the first duties done by the Public Service Commission of the Second district of New York after its creation in 1907 was to investigate the passenger service of the railways of that state. Some of the facts disclosed were very discreditable to railway management. The Commission found a train on one road which never reached its destination on time in July or August. It found a train on another road which was never on time from October 20 to December 1. It found still another on another road which was never on time in November; and yet another on another road that never was on time in December. 
The unavoidable shortcomings of a highly complex machine such as the steam locomotive, and the more avoidable shortcomings of the men who run trains, are to blame for many of them being late. Competition, the prolific mother of so many evils in the railway business, is responsible for many more. Competing railways differ in their lengths between large centers, in their grades, in the condition of their roadbed and equipment, and, consequently, in the time they can make. If they advertised different schedules while charging the same rates the roads having the faster trains would get all the business. Threats by the weaker roads-sometimes executed-to cut the rates unless the stronger roads hold down the running times of their trains result in tacit agreements under which all make practically the same schedules. The result is that the stronger lines do not run their trains as fast as they could, and yet set a pace that the weaker roads cannot keep. The public does not get as speedy service from the stronger roads as it is entitled to, and suffers from trains being chronically late on the weaker ones. The best remedy ever applierl, perhaps, is the arrangement under which the railways between Chicago and New York are divided into two classes, "standard" and "differential," the latter charging a lower basic rate than the former; the rates via different trains on the same road varying with their running times, and the excess fares 
on the faster trains being paid back if they fail to make their scheduled time.

The general incivility of railway employees to passengers always has been one of the worst shortcomings of American railway service. The ticket agent whose answers to travelers' questions are curt and whose manner is supercilious; the churlish conductor; the waiter and porter who inspire every one with a desire to break their heads; the information clerk who tries more to make the traveler feel his want of knowledge than to give him information-are among the railways' worst enemies. ${ }^{1}$ We have all met them. Recently the higher officers have become acutely aware of the extent to which such employees irritate public sentiment, and numerous roads have been conducting campaigns for the education of employees on the subject of courtesy. These efforts are having good results; but much more will be done before the traveler on American railways will get the sort of treatment which he has a right to demand and for which he pays.

In the interest of more economical operation it is desirable that in the freight service of American railways there should be substantial increases in the tonnage hauled per car and per train load. Both cars and engines are able to handle much larger average loads than they do. But, as I have

1 “Railroad Administration," by Ray Morris, page 210. 
pointed out elsewhere, economical operation, whether in the passenger or freight service, is not necessarily efficient operation. From the standpoint of the shipper increased efficiency would in many cases consist in speedier, more regular and more frequent service. Probably the service rendered in hauling the higher classes of commodities between the larger commercial centers of the United States compares well with the similar service rendered in other countries. The railway tariffs in the leading countries of Continental Europe contain two sets of rates, one for ordinary, the other for specially expedited, service. In Germany the railways are required to dispatch quick-service freight from the station within one day after receipt, and to carry it at the rate of 198 miles a day. I have no information as to whether they customarily give merely the minimum service required or better service. Fast freight trains run on regular schedules between Chicago and New York, a distance of 1,000 miles, in 57 hours. Similarly, time freight trains run on regular schedules between Chicago and East St. Louis, a distance of 280 miles, in 15 hours and between Chicago and Kansas City, a distance of 500 miles, in 36 hours. This is typical of the fast freight service rendered between all our large business centers.

The German railways are required to dispatch ordinary-service freight from the station within 
two days after receipt, and to transport it within one day to a distance of at least 66 miles. A further allowance of one day is made for each additional 132 miles. If there is delay for more than twelve hours beyond these requirements portions of the freight charge are refunded unless the railways can prove that no loss has been sustained by reason of the delay.

The fastest and most regular freight transportation in the world is that of England. Consignments of merchandise received at the freight stations in London up to 4 P.M. are delivered throughout the country by 9 o'clock the next morning. To give this kind of service it is necessary to haul very much smaller car loads and train loads than those of our railways, to run many more trains in proportion, to have many more double track and four track lines over which to run them, and to charge the shippers very much higher rates. An engine cannot pull as much at high speed as at low speed, and cars and trains cannot be loaded as heavily on the average when they have to be forwarded on regular and frequent schedules as when they do not.

It is a matter for serious consideration if American railways have not increased the capacity of their equipment unduly, and if the public is not pressing too hard its demands for low rates. Is not the sort of transportation efficiency the need for which our commerce will feel with increasing 
force that consisting, not in relatively slow, infrequent, irregular and economical service, but in faster, more frequent and more regular service? The former can be rendered at less cost to the railway and lower rates to the shipper. But it is not improbable that the difference in service is worth the difference in cost. As our country grows more densely populated, and the amount of short haul traffic in the more valuable commodities increases in proportion to the long-haul traffic in the less valuable, we may conclude that a mean between the extremes of our present comparatively slow and economical freight service and the relatively fast and costly service of England is best adapted to our commercial needs.

Under normal business conditions the traffic of the railways of the United States increases more than 100 per cent. in each decade. ${ }^{1}$ 'To keep pace with this wonderful growth it has been, and will continue to be, necessary for the roads to enlarge the capacity of their plants greatly and at a very rapid rate. The increases in facilities, and in the effriency with which they were operated, did not keep up with the growth of traffic between 1897 and 1907. In consequence our transportation system broke down. The farmer was unable to ship

${ }^{1}$ The increase in passenger traffic between 1897 and 1907 was 125 per cent., and the increase in freight traffic, 136 per cent. 
his wheat and saw it rot on the ground; the manufacturer could not bring raw material to his plant or send finished goods from it; the people of the Northwest were threatened with starvation and freezing-because means were not available for moving the country's commerce. The volume of freight traffic decreased after the panic of 1907. Just about that time the many cars and engines of large capacity which the railways had bought when it was growing so fast, the many new sidings that they had built, and the enlargements of yards and terminals that they had made became available. They have, therefore, been able since then to handle their business-including that of 1910, which exceeded in volume that even of 1907 -without the costly trouble and delays of 1906 and 1907. But when prosperous conditions return commerce will again grow as it did before 1907; and new railways will have to be built; much more equipment will have to be bought; and the mileage of second, third, and fourth track, and of sidings, yards, and terminals, will have to be rapidly and largely increased. The greatest, most necessary and most expensive task of all will be the providing of adequate terminals in cities where the cost of real estate runs from $\$ 100,000$ to $\$ 1$, 000,000 an acre. One has but to realize that the railway managers of the United States must make both their passenger and freight service fastel and more regular and dependable, and at the same 
time provide adequate facilities for satisfactorily handling so swiftly augmenting a traffic, to form some notion of the big task before them. To do that task satisfactorily they must not merely improve railway operation in the United States; they must revolutionize it.

While our railway service has a great many needs, the greatest is that for increased safety. As I have already said, during the fiscal year ending June 30, 1911, 10,396 persons were killed and 150,159 were injured on the railways of the United States. Nor is that record, dark as it is, the blackest. In 1907 the number killed was 11,839, and the number injured 111,016. These figures tell their terrible and pitiful story in terms needing no emphasis. There is a common impression that not only is our railway accident record bad, but that it has been steadily growing worse in proportion to the number of employees and to the amount of traffic handled. This, at least, is not true. Between 1900 and 1910 the passengers killed, per 1,000,000,000 passengers carried one mile, decreased from 15.56 to 13.03 , or 17 per cent., and the employees killed, per 10,000 employees, decreased from 25.07 to 19.9 , or 21 per cent. These figures indicate an improvement. Comparisons of figures for one year with those for another, however, seldom throw satisfactory light on the extent to which changes are taking place in railway affairs. Comparisons of period with period are much more apt 166 


\section{EFFICIENCY AND PUBLIC SERVICE}

to be profitable. Taking the most recent statistics of the Interstate Commerce Commission regarding accidents, ${ }^{1}$ we find that in the four-year period ending June 30, 1907, the number of passengers killed was 2,002 and in the four-year period ending June 30,1911 , it was 1,513 , a reduction of 25 per cent. Similarly, in the former period the number of employees killed was 16,810 , and in the latter, 13,875 , a reduction of 18 per cent.

The Commission's statistics show a larger proportionate increase in injuries than in fatalities since both ten and twenty years ago; but this is rather because a proportionately larger number of injuries is reported now than that a proportionately larger number occurs.

There is, however, no room for question that the accident record of our railways is still very bad. It is the worst made by the railways of any first-class country. But candid analysis of the facts is prerequisite to understanding of them or intelligent suggestion of remedies; and while they are the subject of much denunciation, they are the subject of very little discriminating analysis.

The following table gives the total railway accidents in the United States in the year ending June 30, 1911, as reported by the Interstate Commerce Commission:

'Accident Bulletin No. 40. 
Total, RaH,WA ACODENTS, Ylak ENDED JUNE 30, 1911.
I. Train accidents:
killew.
Injured.
Passengrers
356
13,433
'Trespassers
5,284
5,614
Employees.
3,163
Other Persons
1,154
46,802
9,957
5,073
439
70,922
II. Industrial accidents to employees.
10,396
79,237
Totals
150,159

The significant column in the table is that headed "killed." An injury may mean the loss of a leg, or merely the bruising of a thumb. Whether it shall be reported at all may depend on the judgment of the person making the report as to what really is an injury; the criterion usually applied in the case of employees is whether the employee is disabled for work for three days out of the ten immediately following the accident. On the other hand, a fatality is a constant quantity and therefore is sure to be reported. In our analysis we shall, consequently, confine ourselves to the statistics for persons who were killed.

It will be seen that 51 per cent. of those killed in all accidents were reported by the Interstate Commerce Commission as "trespassers." As the Commission says, they were persons who were stealing rides on trains or walking on railway tracks. These unlawful intruders on the property of railways usually make more than one-half of the number killed. On the average fourteen trespassers are killed on the railways of the United 
States every day in the year. In European countries trespassers are arrested and fined or imprisoned, both to protect the roads and in the interest of public safety. For the casualties to this class of persons in the United States the public is chiefly responsible. As individuals it has persisted in using railway tracks as highways, despite the fact that this is obviously hazardous; and in its collective capacity it has persistently refused to pass and enforce laws to stop trespassing, although this is the only way it can be done. It is a stigma on the American public that it has denounced and attacked every abuse for which the railway managers have been responsible, but has refused to do anything to stop this great evil of trespassing, for which it is responsible. The streets of Jerusalem are said to have been kept clean by each man sweeping before his own door. The American people in their dealings with railways might well follow this venerable example.

It is a common impression that most of the persons who are killed in railway accidents are passengers, and that most passengers are killed in true train accidents, such as collisions and derailments. The table shows that only 356 , or but 3.4 per cent. of the total persons killed were passengers. The railways annually carry almost 1,000,000,000 passengers an average of about 33 miles. This is equivalent to hauling every inhabitant of the country about 350 miles. The total number of 
passengers killed in collision and derailments in 1911 was 141 , or only 1.3 per cent. of the total persons killed in all accidents, and but 2.6 per cent. as many as the number of trespassers killed. One hundred and thirty-one passengers were killed while getting on or off trains, locomotives or cars, or by falling from them. Thirty-nine were killed by being struck or run over by engines or cars at stations or yards. The deaths of the rest were due to miscellaneous causes. Only 142 of the total of 356 were killed in true train accidents.

About 33,000,000,000 passengers were carried one mile in 1911 . Therefore, the average passenger could travel 60 miles an hour for 216 years, or around the earth 4,584 times, without meeting with a fatal train accident. On this showing, the perils of riding on American trains are not so great as newspaper accounts of accidents would indicate.

About 30 per cent. of the fatalities on railways are suffered by employees. The total number of them killed in 1911 was 3,602 . Of these, 209 were killed while coupling and uncoupling cars, in spite of the fact that 99.3 per cent. of the locomotives and cars in service have been, at heavy expense, equipped with automatic couplers. One thousand four hundred and twenty-nine were killed by being struck or run over by engines or cars, which, of course, were being operated by their fellow employees. One hundred and ninety-seven were killed while getting on or off cars or engines. 
Three hundred and ninety-one were killed by falling from trains, locomotives or cars. The deaths of 439 , and the injuries to 79,237 , or a majority of the total number injured, were due to "industrial accidents," resulting from the handling of tools, machinery, supplies, etc., getting on or off locomotives and cars while at rest, and from other causes not at all connected with the movement of trains. The foregoing figures account for over 70 per cent. of the fatalities to employees. The total number whose deaths resulted from collisions and derailments, from locomotives and cars breaking down, etc.-in other words, from true train accidentswas 633 , or but 17 per cent. of the total. The number of persons killed at highway grade crossings was 992 , of whom 124 were described by the Interstate Commerce Commission as "trespassers."

The injuries and fatalities, aside from those to trespassers, are due to three general causes: (1) Shortcomings of railway operating rules and methods; (2) defects of railway plants; (3) lack of proper discipline, manifested by failure of employees to obey the rules of the companies and the orders of their superiors.

Probably the smallest number is owing to the first-mentioned cause. The American Railway Association has developed a code of operating rules which, if employees would obey them, would make most accidents impossible. There are, however, some serious shortcomings in the rules used. 
The block-signaling rules, for example, are not as nearly uniform as they should be. Trainmen often go from the employ of one road to that of another; and owing to this lack of uniformity, and consequent mistakes on their part, accidents sometimes result. There are places where as many as three railways are operating under trackage rights over the same track under three different sets of rules. The danger of this is plain. Sometimes, too, the companies have good enough rules but impose requirements for the movement of trains that make it very difficult for employees at once to meet these requirements and obey the rules.

Again, many accidents are due to defects of railway plants. The Master Car Builders' Association, by years of intelligent and earnest work, developed an excellent set of standard safety appliances for cars, but a good many individual roads, for one reason or another, refused to equip their cars according to one or more of these standards. The result was the passage in 1910 of a federal law requiring the Interstate Commerce Commission to specify the standards to be used. Similarly, every one knows that the only way to stop accidents at highway crossings is to protect them with watchmen, gates or electric bells, or, better still, especially where the traffic is dense, entirely to eliminate the crossings by separating the grades; but the railways are slow to do these things voluntarily. The block signal system-i.e., 
the system of maintaining in one way or another a space interval between trains-is the best means yet devised to prevent collisions, and block signals ought rapidly to be installed on every railway; but while the total mileage operated in the United States is about 240,000 miles, the mileage operated with block signal protection on January 1,1911 , was only about 72,000 miles, or about 30 per cent. of the total. Of this, about 18,000 miles was automatic and about 54,000 miles non-automatic.

We shall never have safe transportation until all these and numerous other shortcomings of the operating rules, methods and plants of the railways have been remedied. But improvements in plants and rules of operation will not alone make transportation safe. Failures of the human element cause most accidents; and you cannot abolish the human element in railway operation, nor prevent its failure from causing accidents, with any number of automatic devices. There is a vein of recklessness in Americans; we chafe under restraint; we like to "take a chance." This leads many employees to disregard rules and orders, and "take a chance" with the limbs and lives of others, as well as with their own. To check this tendency several railways have made use of "surprise signal tests"; that is, one or more officers go out on the line and set signals against the enginemen and note the vigilance with which they observe them and the 
promptitude and strictness with which they obey them. The result usually has been to cause much stricter obedience and increased safety.

Unfortunately, however, while discipline is as essential to safe operation on a railway as to victorious fighting by an army, it grows increasingly hard to enforce it on American railways. The brotherhoods of train employees are the strongest labor unions in the world. They are composed of the most intelligent and best paid workingmen in the world. In many ways they are the best labor unions in the world. But, unfortunately, they have not heretofore exerted themselves to promote the efficiency and safety of railway operation. Indeed, their influence has been in the opposite direction. They have insisted on the rule of seniority in promotion, the effect of which is to put the oldest employees in the most responsible places in the service, whereas the public welfare requires, in the interest both of efficiency and of safety, that the most competent shall be given such positions; and it does not follow in any trade, business or profession that the most experienced will be the most competent. The brotherhoods have been very successful in getting ever higher wages for their members, and I, for one, would be glad of it if only their influence tended to increase the quantity and quality of the work done for these high wages. Similarly, they have made concerted and successful efforts to get legislation requiring rail- 
ways to install safety appliances, to increase the number of men in train crews, to limit the hours of labor; but they have made no concerted efforts to get their members to so act as to increase the safety of transportation. On the contrary, when an employee has committed a violation of rules or orders that has, or might have, caused an accident, and the railway superintendent tries to administer exemplary punishment, he is sure to be waited on by a committee from the man's brotherhood who will, if needful, carry his case to the highest officers of the road; and over and over, because either tacitly or by express words a strike is threatened, the management weakly yields, although it knows that thereby discipline will be impaired. Repeatedly strikes have been not only threatened, but declared, to protect men whose indefensible conduct has endangered the limbs and lives of hundreds; and usually a misguided public opinion has sided with the men instead of with the management which was acting in the public interest.

To educate the public about the true causes of accidents the operating departments of the Union Pacific System and the Southern Pacific Company -the "Harriman Lines" - have adopted the policy, when an accident occurs, of impanelling a board of inquiry, composed of their division officers and representative citizens-local newspaper men being preferred--of having this board make a searching investigation of the cause of the acci- 
lent, and of then giving widespread publicity, on bulletin boards at stations, shops, etc., and through the press, to the facts disclosed and the identity of those at fault, whether officers or employees. This is adapted both to educate public sentiment, and to cause employees, because of fear of disclosure of their misconduct and public condemnation of it, to be more careful.

The Chicago \& North-Western, for the purpose of removing the causes of accidents, has organized "Committees of Safety" on every division, composed of both officers and employees, whose duty it is to go over the line at frequent intervals and investigate both the condition of the railway plants and the conduct of employees. This is bringing about needful coöperation between management and men which must have wholesome results.

No one who investigates the subject of railway accidents, intelligently and without bias, can reach any conclusion but that coöperation between the public, railway managements and railway employees is essential to their reduction. The public should first perform its duty of passing and enforcing laws against trespassing. It should allow the railways to earn enough money to make needed improvements in their plants and should then compel them to make them. And, it should hold railway employees to a stricter accountability for the performance of their duty. 


\section{EFFICIENCY AND PUBLIC SERVICE}

The railway owes special duties to the public because it is a public service corporation. It is not merely the superintendents, the general managers, the presidents and other officers who assume a part of this duty when they enter the service; every employee, from the conductors and locomotive engineers to the track laborers, does so; and when employees organize themselves into brotherhoods these become morally, although not legally, just as truly "public service" institutions as the railway corporations. They have no more moral right to cause a cessation of the railway's public service by striking than the management has by locking them out; they have no more moral right to make the railway's service unduly expensive by insisting on unreasonable conditions of employment or excessive wages than the management has by charging excessive rates; and it is just as much their duty as that of the management to do all they can to make transportation safe and to refrain from doing anything that will make it unsafe. The railway brotherhoods have become a powerful imperium in imperio; and the public will not be as economically, efficiently and safely served as it ought to be until it clearly recognizes the duty of the brotherhoods to it, and makes them recognize that duty and strictly live up to it. 


\section{CHAPTER IX}

RAILWAYS AND INLAND WATERWAYS: COSTS OF RAIL AND WATER TRANSPORTATION

WATERWAY routes may be roughly divided into two classes: (1) Transoceanic routes which afford the only means of transportation between countries or parts of countries entirely, or almost entirely, separated by the sea; and (2) coastwise and inland routes, which may be used alternatively with railways. ${ }^{1}$ The railways are naturally connections, rather than competitors, of the transoceanic routes. While they are often connections, they are more commonly competitors, of the coastwise and inland water routes. ${ }^{2}$ The transoceanic

${ }^{1}$ This classification is not exact, for transoceanic routes afford the only practical means of transportation between some countries which are connected by land; such, for example, as the United States and Argentina, or France and China - but it is sufficiently accurate for my purpose.

$\because$ There is, however, much more competition between the railways and the transoceanic routes than is generally known. For example, goods originating at New York and other points on the Atlantic seaboard may move to the Orient either eastward across the Atlantic Ocean, through the Mediterranean and through the Suez Canal, or westward by rail aeross the United States and then across the Pacific Oce:an. There formerly was active competition between the 
routes being the only means for handling most of our foreign commerce, it follows that if we desire that commerce handled satisfactorily we have no choice but adequately to develop our harbors and otherwise give necessary encouragement to transoceanic traffic. Coastwise and inland water routes, being alternative and competitive with railways, it is an important question of public policy to what extent the public, to secure good and ample facilities for transportation between the different parts of the United States, should give encouragement to the development of coastwise and inland water

transatlantic steamship lines and the transcontinental railways of the United States for this traffic; and the railways and the Pacific Ocean steamship lines often made as low or lower rates from the Atlantic seaboard to the Orient as the railways made for the transportation of the same commodities from New York to the Pacific coast. The Interstate Commerce Commission ruled that the roads must publish separately in their tariffs the amounts that they received for hauling to the Pacific coast goods destined to the Orient. All of the railways in the United States which then reached the Pacific coast replied that they ought not to be required to do this, contending that all the shipper was interested in was the combined through rate of the railways and of the steamship lines; that the proportions of the through rates received by the roads barely covered their operating expenses; and that if they were published they would be invidiously compared with the rates that the roads were receiving for the transportation of goods locally to the Pacific coast. As the Commission insisted on obedience to its ruling the roads withdrew their low proportions of the through rates on Oriental traffic, naking them the same as their domestic rates to the Palcifi: cuast. The Chicago, Milwaukee 
routes, on the one hand, and rail routes, on the other. There has been recently much demand for additional development of inland waterways by the federal government. A project for the construction of a waterway 14 feet deep, or more, from the Great Lakes to the Gulf of Mexico has received widespread support. This main project is supplemented by numerous minor ones, including the deepening of the Mississippi River to St. Paul and of its various tributaries, and of other rivers in all parts of the country; the construction of a ship canal to connect the lower end of Lake Michigan

\& St. Paul Railway, after it built its extension to the coast (the Chicago, Milwaukee \& Puget Sound), made low through rates to the Orient in connection with the steamship lines and published its inland proportions of these rates. But the other transcontinental railways continue to charge the same rates to the coast on export business as they do on domestic business.

Again, a large amount of grain is carried from the Pacific coast via the ocean around Cape Horn to Europe. On their return trips the vessels engaged in this trafic make very low rates on numerous commodities in order to get at least enough lading for ballast. Among the commodities on which these rates are made are cement, and iron and steel artieles. The railways have to fix their rates on these commodities from points in the United States to the Pacific coast with reference to this transoceanic competition in order to enable the American shipper to sell his goods on the Pacific eoast in eompetition with the European shipper.

I should like to hear some alvocate of the distance and the cost-of-service bases of ratemaking tell how the roads could make rates on these bases and meet this sort of competition! 
with Lake Erie; the construction of a ship canal from Lake Erie to the Atlantic Ocean, etc. To finance these great works it has been proposed that Congress shall vote a bond issue of $\$ 500,000$,000 , which amount shall be spent at the rate of $\$ 50,000,000$ annually until exhausted.

The three chief arguments made for this plan are (1) that it would cheapen transportation; (2) that it would regulate railway freight rates; and (3) that it would provide in the best way needed additional facilities of transportation. There are various incidental benefits that it is contended waterway development would confer. It is perhaps not necessary to notice them here, however; for if it can be shown that development of waterways is desirable for transportation reasons, no citation of incidental advantages it would bestow is necessary to make out a case for it; and if the opposite can be shown, it must follow that the incidental benefits it would confer, such as the reclamation of overflowed land along our rivers, should be sought by some less expensive means than the digging of 14 or 20 foot channels.

When it is said that the proposed works would cheapen transportation it is usually meant that they would furnish means by which commodities could be carried at less cost than they can now, or probably can in future be carried by railway. In support of this, the freight rates of boats on the ocean and the Great Lakes, which are much less 13 181 
than those of the railways of the United States, are frequently cited. The most costly parts of a railway's plant to build and maintain are its roadway and terminals; and the physical limitations they put on the size and capacity of the vehicles that can be used cause a large part of the expense of operating railways. Nature provided for ocean and lake boats roadways which have none of the physical limitations of a railway's roadway; and nature, aided - and properly so-by government, provides and maintains the harbors which serve as their terminals. There can be no question that, in consequence, well-managed steamship lines in our coastwise and Great Lakes traffic can generally haul goods more cheaply than railways. The case of artificial waterways, including under this term both canals and improved rivers, is very different. Expenditures analogous to those for the construction and maintenance of a railway's roadway must be made on them; and the expenses of operation caused by the physical limitations of their channels are comparable to those caused by the limitations of a railway's track.

It follows, that data about the cost of transportation on the ocean and the Great Lakes has no bearing on the expediency of digging canals or canalizing rivers. The question to be determined in the consideration of that problem is, not the relative cheapness of transportation by rail and on natural waterways, but the relative cheapness of 
transportation by rail and on artificial waterways.

Nor is the question whether transportation on waterways can be made cheaper than on railways to the shipper the one properly to be considered, as is very commonly assumed. The true question is whether the total cost of transportation can be made less. The rates that shippers pay to the railways cover the total cost of rail carriage. The rates that shippers pay to boats cover only the cost and profit of operating the boats. To arrive at the total cost of water transportation, to the charges of the boats must be added what the public expends on the waterways. It might be that the average rate by rail on commodities adapted to water transportation would be 5 mills per ton per mile, and by boat only 4 mills, and yet that, because of taxes paid by the public to defray interest and maintenance charges on the waterways amounting to 2 mills per ton per mile, the total cost of transportation by water would be greater than the cost by rail. Transportation would not then have been cheapened by waterway development. It would merely have been cheapened to the shipper. And it could have been cheapened equally to the shipper with 50 per cent. less expense to the public, if the government, instead of developing waterways, had paid a bounty of 1 mill per ton mile on shipments sent by rail equal in amount to those carried by water. 
We can best arrive at a rational conclusion as to whether further development of rivers and canals in the United States would cheapen transportation here by studying the past experience of this and other countries. Now, while the traffic of the coastwise routes, the Great Lakes and the railways of the United States has grown rapidly, that of most of the canals and river's of this country has for some years declined. The commerce on all our inland waterways, except the Great Lakes, in 1889 was 40,600,000 tons; and in 1906, only $31,800,000$ tons, a decrease of $21 \frac{1}{2}$ per cent. ${ }^{1}$ The advocates of waterway development reply that the canals and rivers of the United States have not been able to hold their own because they have not been suf-

${ }^{1}$ lt is often said that our merchant marine is declining. This statement is not exactly correct. The tonnage of American vessels engaged in foreign commerce declined from 1,269,681 tons in 1883 to 878,523 tous in 1909, or over 30 per cent. Meantime, the tonnage of vessels engaged in coastwise traffic increased from 2,838,354 tons to $6,451,042$ tons, or 127 per cent. ("Statistical Abstract of the United States," 1909, page 302). The net tons of freight carried by coastwise vessels on the Atlantic coast and the Gulf of Mexico increased from $52,712,124$ tons in 1889 to $140,512,043$ tons in 1906, or 166 per cent. ; and on the Pacific coast, including Alaska, from $11,249,927$ tons to $17,622,816$ tons, or 56 per cent. The vessel tonnage on the Great Lakes and the St. Lawrence River increased from 920,294 in 1889 to $2,392,863$ in 1906 , or 160 per cent. Meantime the net tons carried increased from $25,266.974$ to $75,609,649$, or 199 per cent. ("Special Report on Transportation by Water, 1906," by the Bureau of the Census, pages 14 and 33.) 
ficiently developed, and because the railways have used unfair methods of competition. They call attention to the fact that while the traffic on our rivers and canals has been declining, the commerce on the rivers and canals of Europe has been growing faster than on the railways of Europe. The principal inland waterways of Europe are those of Belgium, Germany and France. The tonnage carried on the waterways of Belgium increased 115 per cent. between 1888 and 1905, while the tonnage on the railways increased only 62 per cent. The ton-miles of traffic carried on the waterways of France increased 154 per cent. between 1880 and 1905, while the ton-miles of traffic on its railways increased only 72 per cent. The ton-miles of traffic on the waterways of Germany increased 211 per cent. between 1885 and 1905, while the traffic on German railways increased only 168 per cent. ${ }^{1}$ Data such as these, it is ar-

${ }^{1}$ The following tables, compiled from Volume VI of the Report of the Royal Commission on Canals and Waterways, show the comparative mileage and the comparative tonnage of the railways and waterways of Belgium, France and Germany. It should be noted that these figures are for tonnage and not ton miles.

\section{Belgium.}

\begin{tabular}{|c|c|c|c|c|}
\hline YeAR. & $\begin{array}{r}\text { LENGTH (I } \\
\text { Waterways. }\end{array}$ & $\begin{array}{l}\text { MILEs). } \\
\text { Railways. }\end{array}$ & $\begin{array}{l}\text { TONNAGE (IN } \\
\text { Waterways. }\end{array}$ & $\begin{array}{c}1,000 \text { Tons) } \\
\text { Railways. }\end{array}$ \\
\hline 1888. & 998.4 & $2,364.7$ & 24,836 & 40,352 \\
\hline 1890. & $1,018.2$ & $2,378.4$ & 25,242 & 42,990 \\
\hline 1895. & $1,009.7$ & $2,407.8$ & 30,242 & 46,664 \\
\hline 1900 . & $1,015.6$ & $2,881.2$ & 38,178 & 55,108 \\
\hline 1903. & $1,015.6$ & $2,874.4$ & 49,020 & 59,297 \\
\hline 1905. & $1,015.6$ & 2.873 .8 & 53,345 & 65,319 \\
\hline
\end{tabular}


gued, show that wherever inland waterways are properly developed and not subjected to unfair competition they furnish service and rates that attract most of the bulky commodities.

On the other hand, some students of the subject contend that the more thoroughly rail and water transportation in Europe and in the United States are investigated the more we shall be convinced that the experience of Europe affords no evidence, at least, that the total cost of canal or river transportation can be made less than the cost of rail transportation is in the United States.

The British Royal Commission on Canals and Waterways issued late in 1909 a comprehensive

France.

\begin{tabular}{|c|c|c|c|c|}
\hline YEAR & $\begin{array}{l}\text { LENGTH (IN } \\
\text { Waterways. }\end{array}$ & $\begin{array}{l}\text { MiLES). } \\
\text { Railways. }\end{array}$ & $\begin{array}{l}\text { TonNAGE (IN } \\
\text { Waterways. }\end{array}$ & $\begin{array}{l}\text { 1,000 Tons) } \\
\text { Railways. }\end{array}$ \\
\hline 1880. & 6,782 & 14,315 & 18,000 & 80,774 \\
\hline $1885 \ldots \ldots$ & 7,676 & 18,500 & 19,573 & 75,192 \\
\hline $1890 \ldots \ldots \ldots$ & 7,670 & 20,634 & 24,167 & 92,506 \\
\hline 1895. & 7,614 & 22,469 & 27,174 & 100,834 \\
\hline $1900 \ldots \ldots \ldots$ & 7,533 & 23,436 & 32,446 & 126,830 \\
\hline $1903 \ldots \ldots \ldots$ & 7,589 & 24,149 & 33,340 & 129,305 \\
\hline $1905 \ldots$ & 7,483 & 24,459 & 34,030 & 139,000 \\
\hline \multicolumn{5}{|c|}{ GERMANY. } \\
\hline 1875. & $* 6,200$ & 16,430 & 20,800 & 167,000 \\
\hline 1885. & 6,200 & 22,940 & 27,600 & 200,000 \\
\hline 1895. & 6,200 & 27,780 & 46,700 & 331,000 \\
\hline 1900. & 6,200 & 30,750 & 73,000 & 487,000 \\
\hline 1905. & 6,200 & 33,730 & 103,400 & 588,700 \\
\hline
\end{tabular}

* Although new waterways, with a length of several hundred miles, have bech constructed since 1 nis, other waterways, aggregating about the same length, have .ntirely Jost their importance and are therefore excluded, so that the tolal length is accepted as unchanged. If all abandoned or insignificant lines are included, the total length of German waterways may be estimated at from 7,709 to 8,500 miles. 
report of its investigation of the waterways of Continental Europe. This, in conjunction with the report on the proposed Lakes-to-the-Gulf Deep Waterway, issued a short time before by a board of United States army engineers, and other official reports of the United States government, ${ }^{1}$ makes possible a tolerably up-to-date comparison of the more important waterways of Europe, those of France and Germany, with those of the United States.

The waterways of France, which are considerably used, include about 4,500 miles of rivers and 3,000 miles of canals. The maximum depth which has been obtained on them is 8.5 feet, while most of the traffic is carried on water varying in depth from 1.5 to 5 feet. The largest estimate of the mileage of the waterways of Germany is 8,500 miles; the mileage on which the traffic is considerable is 6,200 . The depth of the "free rivers" varies from 3 or 4 feet on those such as the Oder, Elbe, and Vistula, which have unstable beds, to 5 or 6 feet on those such as the Rhine and Upper Main, which have stable beds; and on the lower sections of some of the larger rivers the maximum

"“Transportation by Water, 1906," issued by Bureau of the Census; "Preliminary Report of the United States National Waterways Commission:" "Statistical Abstract of the United States, 1909, ' pages 301-322. “'Transportation in Europe,' by Logan G. MePherson (Henry Holt \& Company, New York), contains extremely interesting and valuable information about the waterways and railways of Europe. 
depths are 8 to 10 feet. The depths of the canalized rivers are 2.6 to 7.5 feet; and of the canals, 4 to 10 feet, the latter being very rare, and 4 to 6 leet being most common.

Practically all of the traffic is carried in shallow barges varying in capacity from 100 to 1,000 tons. The great bulk is handled in barges 2 feet to 6 feet deep and having capacities of 150 to 600 tons, which are commonly towed in trains at from $2 \frac{1}{2}$ to 4 miles an hour. Barges of 1,000 tons capacity are confined almost exclusively to the Rhine in Germany and the Seine in France. ${ }^{1}$

The United States government had spent, up to 1907 , over $\$ 208,000,000$ on the improvement of the

${ }^{1}$ Regarding the operation of the water craft in France, L. G. MePherson ("Transportation in Europe," pages 1617) says: "In exceptional cases only does the proprietor of the merchandise transported own the craft. The industry is still that of the small enterprise. Of the boats, other than steamboats, two-fifths both as to number and tonnage belong to boatmen, each of whom has only one boat and sails that boat himself. This proportion, however, has fallen; 10 years ago it was one-half. Another fifth belongs to boatmen, each of whom owns two or three boats and almost always sails one of them himself. Really important cnterprises, each possessing 20 boats or more, scarcely represent more than one-tenth of the total tonnage. The boatmen live on their boats with their. families. Thirteen thousand three hundred boats are provided with cabins which were shown by the last census to be inhabited by 18,600 inen, 10,500 women and 16,200 children, this floating population having no other home. Nearly 3,000 of the boats are provided with stables sheltering their draught animala, 188 
Mississippi Valley waterway system alone; and the Mississippi River now has in its lower section a minimum depth exceeding that of any river in Europe. During seasons of low water boats having drafts of 25 to 30 feet can easily be taken from the Gulf of Mexico 270 miles to New Orleans, Baton Rouge and Bayou Sara. Boats of a draft of 9 feet can always be taken from these points 840 miles to Cairo, Illinois; boats of 8 feet from Cairo to St. Louis, 182 miles; and boats of $4 \frac{1}{2}$ feet from St. Louis via the Mississippi River and Illinois River and the Illinois state canal to Chicago, 365 miles. There is a channel of at least $4 \frac{1}{2}$ feet at low water (7 feet during 1907-8) from the mouth of the Illi-

2,400 horses, 150 mules and 1,950 donkeys." In the Netherlands, says the same authority (page 29), "In a large number of cases the boatman owns his boat and lives upon it with his family; but there are two companies which own about 700 craft each. About 150 separate lines of small steamers give regular service between the numerous towns. Ferry lines and lighters are owned by the railloads, and many of the manufacturing companies own and operate craft engaged especially in their service." In Belgium (page 31): "In nearly every case the boat is navigated by the owner and his family, who live upon it. The boatmen make somewhat more money than the ordinary workingmen, but never a very high profit. These men are helped by an association, which is permitted by law to loan money on mortgages on a boat after it has been built. Because of a certain movement of traffic on the inland waterways between France, Holland and Belgium, there is an agreement as to the size of the boats, in order that those of either country may go through the canals of the others." 
nois River 620 miles up the Mississippi to St. Paul, Minnesota; and a channel of at least 4 feet up the Missouri River to Kansas City, and of $2 \frac{1}{2}$ feet to Fort Benton, 2, 285 miles from St. Louis. At mean stages of water there is a depth in the Ohio of 9 feet from Cairo, Illinois, to Pittsburgh, 1,000 miles; and the Monongahela, a tributary of the Ohio, has a depth of 5 feet into the Pennsylvania coal fields. The Kanawha, another tributary of the Ohio, has a depth of 6 feet into the West Virginia coal fields. Other streams in the Mississippi River system which have channels as good as those of most of the navigated rivers of Europe include the Allegheny, Little Kanawha, Muskingum, Kentucky, Cumberland, Tennessee, St. Croix, Minnesota, Osage, Gasconade, St. Francis, Yazoo, Arkansas and Red. ${ }^{1}$

There are 295 navigable streams and 45 canals in this country having an aggregate mileage of 28,600 miles; and of these, 40 streams, with a length of 2,600 miles, have a depth of 10 feet; and 70 , with a depth of 3,200 miles, have a depth of 6 to 10 feet. $^{2}$ Over 67 per cent. of the total waterborne commerce of Germany is carried on the Rhine and Elbe, yet these two rivers together

'Report of the Special Board of Army Engineers on the proposed Lakes-to-the-Gulf Deep Waterway, mare 24.

"Part I of the Report of the Commissioner of Corporations on Transportation by Water in the United States, pages 28 and 29. 
have only 617 miles of channel with a depth of $4 \frac{1}{2}$ feet or more, while $4 \frac{1}{2}$ feet is the minimum depth on the present waterway of 1,657 miles from Chicago to New Orleans.

We must look elsewhere than to the comparative conditions of the rivers and canals of Europe and of the United States for an explanation of the fact that while on the former commerce has grown, on the latter it has declined. One explanation advanced is that municipalities and private corporations in Europe have provided excellent terminal facilities for boats at cities and large towns, and the concerns running water lines have developed types of towboats and barges which can be operated at the minimum cost, while in the United States there has been almost no improvement in river or canal boats or terminal facilities for 30 years. But, it is replied, the failure to provide good facilities in the United States has perhaps been as much an effect as a cause of the decline of water traffic; would they not have been provided by private enterprise had there been profits in sight to justify it?

An important reason, undoubtedly, why our water-borne traffic has not grown is that our principal waterway system, except the Great Lakes, viz., the Mississippi and its tributaries, is not so situated with reference to the main currents of commerce as to be able to command a large amount of traffic, no matter what rates may be made on it. 
In order that either a waterway or a railway may get traffic and actually cheapen transportation by carrying it, it is not enough that it should be willing and able to make low rates. It must also run in the same general direction as currents of commerce large enough to afford it a substantial business. The general direction in which commerce moves is determined by the economic law of supply and demand. People ship goods to make a profit; they can only make a profit by shipping them from where they are less valuable to where they are more valuable; and where they shall be less valuable or more valuable is determined, since the coming of the railway, by conditions independent of the way in which waterways run. In this country, owing to historic and economic reasons, manufactured goods are shipped mainly from east to west, and the products of the farm, mine and forest mainly from west to east. The amount of traffic which moves north and south, although absolutely large, is relatively small; and there seems no ground for anticipating any substantial change in this respect. As the Mississippi and its tributaries run mainly north and south, it is hard to see where a heavy traffic for them could be obtained for some years to come, even though the boats on them were able to compete successfully in rates against the north-and-south railways.

The situation of the principal waterways of Europe relatively to the main currents of commerce 192 
is more fortunate. The Rhine in Germany, for example, like the Great Lakes in this country, is ideally located relatively to the sources of production and consumption of coal, iron ore, etc., to get a large traffic in them. In Europe, also, commerce grew up before the advent of the railway, and the direction of the currents of traffic has been influenced more by the way the waterways run. Here industry and the more flexible railway have grown up together, each determining where the other should go in substantial disregard of most of the waterways. $^{1}$

${ }^{1}$ The United States National Waterways Commission in its preliminary report (pages $30-31$ ) says: "The increase in traffic on the waterways in Europe, in contrast with the decline on the streams of the United States, is due in large part to the very great difference between conditions in Europe and those in the United States." The following is an abstract of its summary of these differences in conditions:

1. In 1909 the estimated population of the United States was 46 inhabitants per square mile, while that of Germany was 290 per square mile; that of Belgium, 620 ; and that of all Europe, 107. The greater density of population in Europe tends to increase the quantity of freight in a given area; while the railway mileage per square mile in the United States is equal to or greater than that in Europe, and the mileage per 1,000 of population is five times as great.

2. In Europe the waterways were developed and in very general use before the introduction of railways, and factories and warehouses were located with reference to them. It is more difficult to provide railways in Europe because of the very high costs of rights of way; and the opportunity for betterment by eliminating grades and curves is much 
While the fact that the Mississippi Valley waterway system runs transversely to the main currents of commerce tends to show why it has not developed a heavy commerce, it does not explain why its traffic has actually decreased, while that on the competing north-and-south railways has grown. Nor does it explain why the traffic on other waterways having more favorable situations, such as the Erie Canal and the Hudson River, has declined.

Another important reason why the rivers and canals of the United States have been unable successfully to compete with the railways has been the comparative inefficiency and inconveniency of

less. The carrying capacity of the European freight car is but a fraction of that of the United States.

3. Shifting of centers of population, arising from the development of new coal mines and new centers of manufacturing as well as from the growth of population, is much less common in Europe than in the United States. This makes it possible to utilize an established waterway with greater assurance of profit and greater dependence on it as a means of transportation.

4. One social condition which the commission said is entitled to very considerable weight is the existence in Europe of the class of boatmen who for generation after generation apply themselves to the handling of boats in river or canal traffic. They live with great economy on their boats and are contented with very small gains and with conditions which would not be regarded favorably in the United States.

5. "Engineering difficulties, as a rule, in those rivers which are most utilized are less serious on the rivers of Europe than in the United States. The most notable example of this is the river Rhine. Its sources are in the Alps, 
the service rendered by the boats. The railways have soliciting staffs engaged constantly in beating the entire country adjacent to their lines for traffic. The larger systems have traffic representatives in all the big cities, whether their lines reach them or not. If a shipper has a consignment of freight to send he can always find a solicitor of the road over which he wishes to route itif, indeed, the solicitor does not find him first. When he delivers goods to the railway it issues to him a merchantable and bankable bill of lading which almost absolutely protects him against loss of and damage to his goods. On the other hand, if a shipper desires to make a shipment by even

where the melting of snow and ice during the hot weather of summer furnishes a constant supply for the water flow of the river at the very season when rivers are likely to be lowest in the United States. Furthermore, it should be said that conditions as regards alluvial banks and shifting bars due to deposits of silt, are on the whole more favorable to river improvement in Europe than in the United States, and especially so upon rivers whose improvement would be most useful.",

6. "Military conditions have been much more regarded in Europe, not only in the construction but in the management of transportation lines than in the United States. Railways are laid down to connect the center with the frontier, or, at any rate, are located with a view to the mobilization of troops and to the carrying of supplies to places where they may be needed, and with a less uniform regard for serving great manufacturing centers or populous cities. Waterways are located mainly with a view to the development of trade at all times and to relieving the railroads in time of war." 
an inclependent boat line on the Great Lakes he has first to hunt up a captain who may have two or three boats available or who may not. On delivering his goods he gets a mere receipt which affords him little or no protection against loss and damage. The inconveniencess and hazards of shipment by river or canal are similar to, but much greater than, those of shipment by independent lake boat lines. The result of these conditions on the Lakes has been that while the total traffic has increased, the amount of it handled by independent boat lines has remained stationary or declined. ${ }^{1}$ Of course, conditions such as these have put the river and canal lines at still greater disadvantages than the lake lines in competing with the railways.

Undoubtedly the main reason why the waterborne traffic of the United States has decreased while that of Europe has increased is the wide

${ }^{1}$ The total shipments on the Lakes in 1906 (Census report on Transportation by Water, 1906, page 34), excluding bunker coal, were about $75,000,000$ tons. Of this about $41,000,000$ tons were iron ore or its products belonging to, and carried in vessels owned by, the large steel corporations. Very much the greater part of the rest of the traffic was carried in vessels belonging to railways, and to coal companies, lumber companies, oil companies, etc., which also owned the cargoes. Practically all of the shipments of package freight are carried by railway boat lines. The lake lines operated by the large industrial corporations are not common carriers; they do not hold themselves out to serve the public. It is estimated that not to exceed 20 per cent. of the freight 
difference between railway freight rates here and abroad. The average railway rate per ton per mile in Belgium is almost 15 mills; in France, 12.8 mills; and in Germany, 12.7 mills. In the United States it is 7.53 mills, or 50 per cent. of what it is in Belgium, 59 per cent. of what it is in France, and 60 per cent. of what it is in Germany. Mere averages which take no account of differences in conditions and methods of transportation may mislead, but, allowing for all such differences, it is quite safe to say that railway freight rates here are lower than in Europe, especially for long hauls and for cheaper and bulkier commodities. In fact, the rates of American railways compare favorably with those of European waterways. On the Rhine in France the rates vary from 7 mills to 14 mills per ton per mile; on the Seine, from 2.3 mills to 5 mills; on the Canals du Centre and du Midi from 5.5 to 7 mills; on the canals in the north-

transported on the Lakes is carried by common carriers, of which a large majority are railway boat lines. The railways, and even large industrial corporations, sometimes have been criticised for having got control of so many of the lake steamship lines. But it is doubtful whether, if all the lake steamship lines were operated by independent companies, the traffic would be as large as it is. The traffic of the large industrial corporations cannot, of course, be attracted from lines owned by them; and the railway boat lines get a good deal of business that independent boat lines would not get because their traffic is solicited for them in the same way that it is for the railways, and often by the same staffs. 
aast and east of France fiom 3.4 to 4.1 mills. The arerage rate on a wide variety of commodities moving to Paris, where the traffic is very dense, is 5.17 mills. ${ }^{\prime}$

The average rates per ton per mile on the waterways of Europe have never been officially ascertained; but from a careful study of the figures given by the British Royal Commission I think it is safe to conclude that the average rate on all the waterways of France is certainly not less than 6 mills; on the waterways of Germany, about 5 mills; and on those of Belgium about 6.5 mills.

Before these rates can fairly be compared with those of railways several facts must be considered. A waterway usually is longer between any two points than a railway. This makes its rates seem lower than they are. If the distance by rail between two points is 100 miles and by water 150 miles, and the rate by both rail and water is $\$ 1$ per ton, the average per mile by rail will be 10 mills, and by water only 6.6 mills; but the greater distance which makes the waterway's average rate per mile lower will also hinder the waterway from getting traffic. Now, the distances on which these average rates for the waterways of Belgium, Germany and France are computed are at least one-third greater than the distances by rail. Computed on the distance by rail, the average rate by

1 These rates are all reduced to the basis of the short ton of 2,000 prounds. 
water in Belgium and France would be about 8 mills and in Germany about 6.5 mills.

Furthermore, the average railway rate for an entire country includes the comparatively high rates on many high grade commodities which seldom can move by water and the rates on many roads running through mountainous territory where operating expenses are greater and rates are apt to be more than on the low grade railways with which waterways mainly compete. While the average railway rate per ton mile in the United States is (1910) 7.53 mills, the averages are much lower on many American roads having low grades or handling traffic consisting largely or mainly of cheap and bulky commodities. For example, the average rate per ton per mile of the New York Central in 1909 was 6.2 mills; of the Erie, 6.1 mills; of the Pennsylvania Railroad, 5.67 mills; of the Illinois Central, 5.96 mills; of the Lake Shore \& Michigan Southern, 5.21 mills; of the Big Four, 5.56 mills; of the Norfolk \& Western, 4.6 mills; and of the Chesapeake \& Ohio, 4.1 mills.

It would seem from the foregoing that the cost of water transportation in Germany and France to the shipper is on the average no less than on American railways. ${ }^{1}$ The total cost is substantially

The United States National Waterways Commission says in its preliminary report: "The average European freight rates on railways paralleling water routes are higher than those on lines similarly situated in the United States, 
greater than the cost to the shipper. The expenditures of the French government for maintenance of canals and improved rivers and for interest on the money laid out in their development amounts to 3.6 mills per ton per mile for all water-borne traffic.' The similar expenditures of Belgium are 4.1 mills; and those of Germany, seven and sixtenths of a mill per ton per mile, including the Rhine and the Elbe on which the traffic is very large; excluding them, 1.8 mills per ton per mile. This makes the total average cost of water transportation in France, estimated according to waterway mileage, 9.6 mills per ton per mile; and, estimated according to railway mileage, 11.6 mills. It

and European rates for water-borne carriage, in some instances, even where the traffic is very large, are as high or higher than on railways in the United States where traffic is likewise large."

In spite of the comparatively shallow depths that have been secured the expenditures on European waterways have been very large. The expenditures of Franee on its navigable rivers have averaged $\$ 30,000$ a mile, and on its canals $\$ 102,675$ a mile. Germany has spent on its navigable rivers an average of $\$ 30,300$ a mile, and on its eanals an average of $\$ 42,250$.

Where unusual engineering difficulties have been encountered, or considerable depths have been obtained, the cost per mile of building canals or canalizing rivers abroad has greatly exceeded the figures given. The expenditures on the river Rhine have been $\$ 61,600$ a mile. The canalization of the Main in Germany, a distance of 22 miles, cost $\$ 95,000$ a mile: the building of the Teltow Canal, $\$ 390,000$ a mile. "The new works on the Seine" (in France), say's the Brit- 


\section{RAILWAYS AND INLAND WATERWAYS}

makes the total average cost of water transportation in Germany, estimated according to waterway mileage, very close to 6 mills; and, estimated according to railway mileage, not less than 7.5 mills. It makes the total average cost in Belgium, based on waterway mileage, 10.6 mills; on railway mileage, 12.6 mills. In Germany it just about equals, and in France and Belgium very greatly exceeds the average cost of rail transportation in the United States.

It is not possible to estimate what is the average rate per ton per mile on the rivers and canals of the United States. A careful computation' ${ }^{1}$ indicates that the cost of transportation per ton per

ish Royal Commission, “cost $\$ 90,500$ a mile; but existing works were partly utilized, so that the entire cost would have been somewhat higher. The cost of the further canalized rivers varies in round figures between $\$ 27,350$ for smaller rivers and $\$ 83,500$ for those with less favorable conditions."

The Kaiser Wilhelm Canal, 61 miles long and $29 \frac{1}{2}$ feet deep, cost $\$ 656,000$ a mile. The Manchester Ship Canal, $35 \frac{1}{2}$ miles long and 26 feet deep, cost $\$ 2,113,000$ a mile. The Suez Canal, 90 miles long and 31 feet deep, cost $\$ 1,100,000$ a mile. Our own canal at Sault Ste. Marie, 2.7 miles long and 25 feet deep, has cost $\$ 4,800,000$ a mile. Some persons advocate converting the Mississippi and connecting waterways into a ship canal from Chicago to the Gulf of Mexico, a distance of 1,657 miles. The figures given show that the longer it is necessary to make a ship canal the more dubious becomes the expediency of building it.

${ }^{1}$ Bulletin No. 21, Bureau of Railway Economics, Washington, D. C. 
mile on the Erie Canal in 1909 was: interest on capital, 5.06 mills; cost of maintenance, 1.55 mills; rate paid by shipper, 2 mills; total cost per ton per mile, 8.61 mills. This compares with the following average rates per ton per mile on competing railways: New York Central, 6.2 mills; Erie, 6.1 mills; Lackawanna, 7.4 mills; Lehigh Valley, 6.4 mills.

Computed at $3 \frac{1}{2}$ per cent., the interest alone, on each ton of freight hauled one mile in the Sault Ste. Marie Canal in 1910, was 2.7 mills; and in 1908, when the traffic was smaller, it was over 4 mills. ${ }^{1}$ This does not, of course, indicate that construction of the canal was unwise, for it serves to cheapen transportation on all the Great Lakes, which were provided by nature; but it may throw light on what would be the economic cost of transportation on longer ship canals which might be built, not to connect and make more serviceable such great already existing waterways, but to serve as independent transportation facilities.

Transportation by rail is faster and better than by water. The freight car can move as well into a shipper's warehouse to get goods as on the road's main line, while all goods shipped by water must in some way be hauled to and from the water's side and be transferred to and from the boat. Therefore, to compete successfully with railways,

'Railwa! Age Gazette, August 11, 1911. 
boats must make rates to shippers not only as low as, but lower than those of railways. Experience in Europe and the United States shows that they must ordinarily be 20 to 50 per cent. lower. The conclusion is inevitable that if our waterways and their equipment were in the exact condition of those of France and Germany, and made equally low rates, they would fail as utterly in the future to compete successfully with the railways as they have heretofore.

Some of the advocates of further development of waterways apparently see this fact. They therefore favor the proposed Lakes-to-the-Gulf waterway and other waterways being dug 14 feet deep or even 20 feet or more; and they paint attractive pictures of great vessels loading at Chicago and St. Louis, and steaming without transfer of goods through the country to the Gulf, and thence to all the ports of the world. But if the waterway were deepened to only 14 feet hardly any boats could use it which cannot use it now, for over 95 per cent. of the vessel tonnage on the Great Lakes draws over 14 feet of water, and more than 80 per cent. draws over 19 feet; and, of course, seagoing vessels cannot navigate where lake vessels cannot. Even if the Lakes-to-theGulf waterway were dug 20 feet, or even 30 feet, it is not probable it would be used by lake or ocean steamships. The average cost of an ocean steamship per ton of capacity is $\$ 71$; of a lake steam203 
ship, $\$ 11.50$; and of a river towboat and barges capable of carrying 10,000 tons of freight on an $\$ !$ foot draft, only $\$ 12 .{ }^{1}$ Moreover a lake or ocean vessel is poorly constructed for navigating a canal ol tortuous river with a swift current; its ratio of length to beam is too great and its rudder power insufficient to keep it from frequently running into the banks, except when moving very slowly. Colonel Thomas W. Symons, of the corps of engineers of the United States army, in a report in 1897 on the proposed deepening of the Erie Canal, estimated that the cost to the shipper of transporting wheat in a lake freighter of 7,000 tons capacity through a ship canal would be 38 per cent. greater than with a towboat and barges on a barge canal. ${ }^{2}$

${ }^{1}$ Report of Board of Army Engineers on Proposed Lakesto-the-Gulf Deep Waterway, page 24.

"If the proposed development of waterways woutd reduce what I have called the "total" cost of transportation, it is quite obvious that it would be practicable for boat owners to make rates which would be high enough to cover a return on the government's expenditures, and yet low enough to attract traffic from the railways. When the United States reclamation service builds an irrigation ditch, it requires those whose lands are watered to pay for the water; and there is no more reason why the government should provide facilities of transportation for boat owners or shippers for nothing than why it should provide irrigation for farmers for nothing. In some cases governments have levied tolls on canals and improved rivers; but in no case since the advent of the railway has it been possible to get in this way enough revenue to pay interest and maintenance charges. 


\section{RAILWAYS AND INLAND WATERWAYS}

This took no account of the fact that the esti

- mated cost to the public of building the ship canal would be four times greater than of building the barge canal. The Mississippi waterway system and many other of our rivers and canals could be used as well now by boats such as those on the waterways of Europe as if it were much deeper; and if they were much deeper they could not and would not be used by either lake or ocean vessels. 


\section{CHAPTER $\mathrm{X}$}

INLAND WATERWAYS AS REGULATORS OF RAILWAY RATES

THE second argument for waterway development to which I have alluded is, that it would regulate freight rates. By this is meant, of course, that it would reduce the rates of competing railways. Railway rates in all parts of the United States always have been, and are now, considerably affected by the competition not only of the coastwise and Great Lakes routes, but also of rivers and canals. Along the Mississippi River, all the way from New Orleans to St. Paul, they are lower than they would be if uninfluenced by the river's presence. The rates between Buffalo and New York always have been considerably affected by competition via the Erie Canal and the Hudson River. Between innumerable other points, particularly in the Southeast, railway rates are influenced by minor streams which parallel the railways.

It is possible that by adopting a comprehensive and efficient policy of waterway development the public could considerably increase the number of places where water competition would reduce rail206 
way rates. ${ }^{1}$ It would not be sufficient, in order to make rivers and canals more effective competitors of the railways, for the government to provide the necessary channels. To a railway good and adequate terminals are as essential to economical and satisfactory operation as good roadway. Likewise, to water routes, good and adequate terminals are as essential as good channels. Before the channels the government provided could be utilized to any purpose it would be necessary for the various municipalities on the waterways to either provide good water terminals or give private capital the opportunity and incentive to do so. Many of the municipalities of Europe have themselves provided water terminals, and allow all carriers to use them on equal terms. Finally, after the government had provided the channels and the municipalities had provided, or caused to be provided, the terminals, it would be necessary for those running the boat lines to furnish better boats and to form better organizations for soliciting and handling the

${ }^{1}$ The most efficient policy would by no means involve the digging of deep channels, for, as has already been indicated, a towboat and barges having a capacity of eight or ten thousand tons can be built for less than one-third as much as a lake freighter having a similar capacity, and can be operated much more cheaply on a river or canal with a depth of from six to nine feet than a lake freighter could be on a river or canal having a depth of even twenty feet. To build canals of much length or to canalize rivers to more than nine feet deep would be sheer waste from any standpoint. 
business than have ever been known on any of our inland waterways, excepting the Great Lakes.

Many of the rates heretofore made by the railways to points of water competition have been designed not merely to meet this competition and secure a division of the traffic, but have been war measures intended to destroy competition, and have produced the intended result. Sometimes they have been less than the cost of the service. In numerous cases after the water competition has been destroyed, the railway rates have been raised. For the protection of the waterways from this extreme form of competition the Mann-Elkins act, passed in 1910, put into Section four of the Interstate Commerce Law a new provision. This is as follows:

Whenever a carrier by railroad shall in competition with a water route or routes reduce the rates on the carriage of any species of freight to or from competitive points, it shall not be permitted to increase such rates unless after hearing by the Interstate Commerce Commission it shall be found that such proposed increase rests upon changed conditions other than the elimination of water competition.

This legislation will restrain the railways in future from making any rates to meet water competition which will not in the opinion of their traffic managers be permanently remunerative, and will in a good many cases protect the waterways from 208 
such ruthless competition as they at times have encountered in the past.

But, while waterway development might affect railway rates at a good many points, it seems highly questionable if its results in this respect would be as great as its advocates believe. Waterways cannot compete with railways for traffic in the more valuable commodities. The railway rate is so small compared with their value and the importance of speed in their transportation that no rate which the water lines with their slower service could make would attract them from the railways. To compete effectively with the railways for the cheaper and bulkier traffic our rivers and canals would have to make lower rates than have ever been made by such waterways in any country in the world. For it is precisely in the cheapness with which they can transport these commodities that our railways excel all others. In Europe freight cars have a capacity of only 10 to 15 tons. In the United States their average capacity is 35 tons. The difference in locomotive tractive power is in proportion. Owing to these and other conditions the railways of the United States can haul very much larger car loads and train loads of bulky commodities moving in large quantities than those of Europe; and this reduces the cost of hauling each unit of traffic to a minimum. The average train load in England may not exceed 100 tons; in France it is 177 tons; in Prussia-Hesse it is 
233 tons; in the United States it is 363 tons; and the train loads in which the bulky commodities such as coal, ore and lumber-are handled in this country far exceed this average. Trains transporting 3,000 tons of coal are not uncommon; and occasionally trainloads of more than 5,000 tons are hauled. The Virginian railway in 1909 with a Mallet engine ran a train composed of 120 steel coaches, which was a mile and six feet long and which transported 6,000 tons, or 12,000,000 pounds, of coal. In order that boats may handle traffic most economically it is necessary that they shall handle it in large quantities. In order that they may do this it is necessary to accumulate it until the maximum cargo is secured. If railways are given a chance to handle bulky commodities in the same way, it is not improbable that with low grades and large modern engines they can transport them at as low operating costs as even lake or ocean steamships. The average operating expenses per train mile on the railways of the United States in 1909 was $\$ 1.43$. Suppose it cost the Virginian railway three times this, or $\$ 4.29$ a train mile to haul the 6,000 tons referred to; the cost per ton per mile, thenincluding transportation and maintenance expenses, but allowing nothing for fixed chargeswas but iun of one mill! Of course, this is an extreme illustration. I have given it merely to show how cheaply low grade comnodities can be trans210 
ported by railways under conditions similar to those under which large lake freighters or steamboats drawing barges handle them.

On the whole it seems improbable that boats on most of our inland waterways would be able to make rates which would enable them to compete effectively against the railways, if no restrictions were put on the competitive action of the roads except those designed to prevent them from taking traffic away from the waterways by making rates which would be unremunerative - which, in other words, would add less to their earnings than the handling of the traffic thus secured would add to their operating expenses. A railway ought not to be $\mathbf{p}$ ərmitted to make such unremunerative rates to meet water competition; or, indeed, for any other purpose; for when this is done the road must, if it is to earn a fair return, make good what it loses on the competitive traffic by imposing unnecessarily high rates on other traffic. A railway ought not to be allowed to get, by imposing unnecessarily high rates on some of its patrons, the means for destroying water transportation enjoyed by other patrons.

If the railways are not allowed in the future as in the past, within the limitation just indicated, freely to reduce their rates to meet water competition the waterways will not regulate railway rates ${ }^{1}$

${ }^{1}$ The governments of Continental Europe have firmly restrained the railways from competing effectively with the 
and if the public desires the waterways to regulate railway rates it will have to let the railways reduce their rates to meet the rates of the waterways and take the risk that they will thus attract business from the waterways.

This latter policy would aggravate the discriminations in railway freight rates to different communities about which there is now so much complaint. For the main cause of these discriminations is that where the railways encounter effective water competition they make lower rates than they make elsewhere. With every increase of water competition there would be an increase of discrimination. All the people of the country would be taxed to pay for the development and maintenance of the

waterways, and this has been one of the reasons why waterborne traffic has increased faster there than here. The United States National Waterways Commission says (Preliminary Report, page 31): "Sedulous care is taken by most European countries for the protection of water-borne traffic against railway competition. In France this is accomplished by forcing a differential of 20 per cent. in favor of the waterways as against the railways" (i.e., the railways are required in all cases to make their rates at least 20 per cent. higher than those of the competing lines), "with the evident intention of maintaining both methods of transportation. In a majority of other countries in which water transportation has reached its highest development the railways, wholly or partially, belong to the state. This is true in Germany, Austria, Hungary, Holland and Belgium. The well-established policy in these countries is to secure coöperation between the railways and waterways by oflicial control of railway rates with a view to maintaining profitable traffic on the latter." 
waterways; but only those adjacent to the waterways would get the benefit of any resulting reductions in railway rates. The communities not on the waterways would actually be injured. It is the relation between rates that mainly counts; and a community may be as much harmed by reductions in the rates of a rival community as by advances in its own.

It is sometimes said that such discriminations in rates could and should be prevented by passing a law requiring railways to make rates as low in proportion where they do not encounter water competition as where they do. But the railways cannot afford to reduce all their rates to the level of those made to meet water competition any more than the manufacturer or merchant could afford to reduce all his prices to the basis of those made to get rid of surplus and otherwise unsalable goods. The effect of such legislation would be to force the roads in many cases to quit making rates to meet water competition. This would not benefit places without water transportation; for the communities having water transportation would still enjoy the low water rates. It might actually injure communities without water transportation. For the law will not permit the railway to be denied a "fair return." If it quit meeting the water rates it would lose whatever traffic it had got to points having water transportation; and if this reduced its aggregate profits below a "fair 
return," it legally conld make up the deficit by advances in rates to communities without water transportation. These communities would then have paid taxes to secure for rival communities low water rates and for themselves the privilege of paying higher railway rates.

Up to this time in the discussion of regulation of railway rates by waterways I have dealt only with the question whether the proposed development of waterways would reduce the cost of transportation to the shipper. But, as I have already said, the important question for the public is whether it would reduce the total economic cost of transportation, including the rates the shippers would have to pay to the owners of the boats, and the taxes that the public would have to pay for the development and maintenance of the waterways. It being doubtful whether the proposed waterway development would reduce the cost of transportation to the shipper, it is, of course, very much more doubtful whether it would reduce the total economic cost. It can be said without any hesitation that in all the discussions of the development of waterways no evidence whatever has been adduced that the building of canals and the canalizing of rivers would reduce the economic cost of transportation in the United States. All the data bearing on the subject that I have been able to find has tended to lead me to the opposite conclusion. 
Despite this, if the development of waterways was the only means available for the regulation of railway rates one might be disposed to favor it. But we have 43 state commissions and an Interstate Commerce Commission charged with the duty of making railway rates reasonable, and a Commerce Court created especially to hear appeals from decisions of the Interstate Commerce Commission. If the commissions do their duty they will keep railway rates reasonably low. If waterway development should then further regulate them, its effect would make them unreasonably low, at least at competitive points.

If waterway development reduced the cost of transportation to the shipper without reducing the total economic cost of transportation, and at the same time pulled down railway rates unduly, it would take money out of the pockets of the public and the pockets of the railways in order to put less than the combined sums taken from them into the pockets of the shippers.

The third argument in favor of further development of waterways which I have mentioned is that it would provide in the best way needed additional facilities of transportation. That rapid expansion of such facilities is needed is not questionable. Every fall and winter for some years before the panic of 1907 the country suffered from what were called "shortages of cars," but what were really shortages of railway facilities in general. Owing 
to large increases of facilities and improvements in methods of operation the railways have since handled the heaviest traffic in their history, that of 1910 , without serious general congestion or delays. But commerce soon will be growing rapidly again; and unless means of transportation are increased proportionately periods of "car shortage" will recur.

The object of public policy should be to cause such additional facilities to be provided, whether by the expenditure of public or private capital, as will, at the least cost, move most freely the increased commerce of all parts of the country. I have already sought to show that it is improbable that rivers and canals can be so developed as to make the cost of transportation by water lower than by rail. It is even more improbable that their development would provide as effectually for the free movement of the commerce of all parts of the country as would expansion of the facilities of the railways. It is practicable to develop rivers and canals only in certain sections; and these are not necessarily the parts of the country which most need additional facilities of transportation. As already remarked, the principal river system of this country runs North and South, while the great currents of commerce flow East and West. The most severe congestions of traffic in the winter of 19061907 were on the railways running from the Pacific coast to the Great Lakes, from 216 
the Trans-Missouri country and the Southwest to Galveston, and from Chicago and St. Louis to the Atlantic seaboard. The Mississippi and its tributaries were at that time in as good condition to bear a large commerce as any waterways in Europe; yet they were not resorted to to relieve the situation.

Nor does past experience warrant the hope that any money which may be spent by the government for the improvement of our rivers will be so laid out as to do the most practicable good. Where such expenditures have been made heretofore has been determined, not by broad and statesmanlike consideration of the interests and needs of the whole country, but by log-rolling combinations between members of Congress dictated by the petty motive of local greed. On the other hand, it is perfectly feasible to secure expansion of the facilities of the railways in proportion to the needs of the whole country and of each part.

Most of our railways are but skeletons of what they should be made. Our total railway mileage is over 240,000 miles, and of this only 22,000 miles is double tracked. While it costs much less to build the second than to build the first track, the capacity of the road is thereby quadrupled. The Board of Army Engineers estimates that it would cost $\$ 160,000,000$ to dig a channel 14 feet deep from Chicago to New Orleans, 1,657 miles. This would build and equip almost 2,000 miles of low 217 


\section{TWE AMERICAN TRANSPORTATION QUESTION}

grade, double tracked, well-equipped railway. Or, it would build and equip 3,500 miles of good low grade single track railway. Or, it would double track 5,500 miles of existing single track railway, thereby increasing the capacity of the American railway system the equivalent of 22,500 single track miles. The $\$ 500,000,000$ which it is proposed to spend on inland waterways during the next ten years would build and equip 5,000 miles of good low grade, double track railway. Or, it would build and equip 10,000 miles of good low grade, single track railway. $\mathrm{Or}$, it would double track almost 20,000 miles of existing single track railway, which would be equivalent to an increase of almost 60,000 miles. It should be noted that the figures for railways include terminals and necessary cars and locomotives for handling the passenger and freight traffic, while the figure for the proposed waterways includes nothing for the boats and terminals provision of which to handle a heavy traffic would cost a large sum. As I have already shown, the average traffic per mile per year on the waterways of France is 420,000 ton miles and on the waterways of Germany, 1,500,000 ton miles. The traffic density of the Elbe is $5,800,000$ ton miles and that of the Rhine, which is the greatest in Europe, 11,400,000 ton miles. The railways of the United States, which are practically a single track system, in 1910 hauled 1,085,745 tons one mile and 138,250 passengers one mile per mile of 
line. Numerous single track railways are handling much more traffic per mile than are the waterways even of Germany; and the numbers of ton miles per mile of line handled by some of the double or multiple track railways are as follows: Delaware, Lackawanna \& Western, 3,766,323; Pennsylvania Railroad, 4,409,694; Bessemer \& Lake Erie, 6,498,677. These figures show that the traffic capacity of a well-managed American railway is comparable to that of the greatest inland waterways. Furthermore, when additional railway facilities - whether they consist of improvements in old lines or of new lines-are provided by private capital we may be sure that they will generally - although not always - be provided where they will be of the most public utility. For private capitalists naturally would invest where the largest profits were to be secured; that would be where there was available the largest traficic; and those places where the largest traffic is available are those where there is the greatest need for additional means of transportation. The public can obtain the needed increase of railway facilities by following a policy of regulation, which, while protecting the rights and interests of the public, will not make investment in railways less attractive than in other businesses.

It is sometimes said that while the government should afford every reasonable encouragement to the expansion of railways, it should also develop 
waterways to serve as auxiliaries. But development both of railways and of rivers and canals may often involve wasteful duplication. The river or canal under modern conditions is adapted only to the carriage of cheap and bulky commodities. Each community needs a railway to haul goods requiring faster and better carriage. As, once the railway is built, it requires all the traffic it can get, high grade or low grade, to operate most economically per unit of traffic, it is usually able, if allowed freely to adjust its rates, to underbid the river or canal for even low grade traffic. ${ }^{1}$

It is easily conceivable that, in a country where changes in commercial and industrial conditions

${ }^{1}$ There are facilities of transportation the scientific and systematic improvement of which by the federal and state governments would reduce the congestion of traffic on the railways and lower the cost of trnsportation without involving wasteful duplication. These are the public highways. From about February 1 to October 1 of each year the railways have many thousands of idle cars. Late in September and early in October the traffie sweeps on them in a deluge: and for about four months there is a car shortage instead of a car surplus. These annual alternations of car satiety with car famine are due largely to the condition of the public Lighways. In the greater part of the United States the snows, and the alternate thaws and freezes, of fall and winter, put the highways in such bad shape that it is hard or impossible to pull a heavily loaded wagon on them. In consequence, most farmers rush their crops to market soon after harvest. At the same time the railways have to haul the larger part of the coal traffic; and thus they are swamped. If the highways were put in grood condition the farmers could hatul their crops to the railway stations more 
occur so rapidly as in this, the time might comeeven within a comparatively few years - when additional development of waterways would be justifiable and desirable. But the criterion of whether it is desirable at any particular time should be the extent of the use made of good channels previously provided. The government having provided as good channels as can be found elsewhere, nothing less than such utilization of them as vindicates past expenditures can afford rational ground for inferring that their future improvement or the construction of new channels will be justified by resulting public benefits.

at their convenience, and the annual congestion of traffic would be alleviated. The country's annual bill for transportation would also be much reduced. Mr. Frank Andrews, Expert in Transportation of the Department of Agriculture, estimates, after a thorough investigation, that the average cost per 100 pounds of hauling wheat from the farms to the railway stations is 9 cents; of hauling corn, 7 cents; of hauling cotton, 16 cents; and of hauling oats, 7 cents. The average lengths of the hauls are 5 to 10 miles. The average rail-and-ocean rate on grain from St. Louis via New York to Liverpool is less than 15 cents per 100 pounds. It is obvious that there is a great deal better opportunity to reduce the cost of transportation by improving the public highways than by improving either railways or waterways. 


\section{CHAPTER XI \\ GOVERNMENT REGULATION: WHO SHALL REGULATE?}

That the railroads of the United States always in future ought to be subjected to public regulation every one now concedes - at least in public utterance. The adrocates of laissez faire, if not converted, have at least been silenced. The main question now in issue is, not whether there shall be regulation, but who shall regulate, and how.

Many who hold otherwise very different views agree in fearing that a satisfactory policy of regulation will not be worked out. One class apprehends that regulation will be too weak and ineffective to remedy the shortcomings and curb the abuses that it considers almost ineradicable chalacteristics of private railway ownership and operation. Another class fears that regulation will be so unintelligent, pervasive, drastic, and burdensome, that it will take the life out of railway managers; make rates inelastic and ill-adapted to commercial needs; repel capital from the railway business; and cauce the service rendered. to deteriorate and the facilities provided to he inarlcquale. These two classes of persons, while dnticipating 
such different mediate results of government regulation, concur in thinking that its ultimate result will be government ownership.

The experience of Europe is cited. Germany, Belgium, Italy, Austria, Switzerland have gone from government regulation to government ownership. France, after long owning and operating one small road and exercising strict supervision over six large lines, has taken over one of these big lines-the Western. But European experience, while instructive, is not conclusive. Special conditions have in every case caused public regulation to be succeeded there by public ownership. Our political and industrial history and institutions are different from those of European countries; and in this matter, as in some others, we may, perhaps, find it more expedient to be taught by their experience than to follow their example.

There is, however, some ground for each of the views that have been outlined. What time shall bring forth will depend on both the railway owners and managers, and the public. The internal management of our railways was never so honest and efficient as now. Never did their rates and service merit so much public approval and so little public condemnation. But there are still shortcomings and abuses - numerous unfair discriminations in rates and service; more or less serious deficiencies of operation and service; occasional discreditable manipulations of finances; in some 
places dictation in and corruption of polities. Public sentiment rightly demands the correction of these conditions. The railways ought to correct them without the compulsion of law. Past experience indicates that if they do not, more and more legislation for the regulation of more and more details of their business will ensue. If this be ineffective the public will likely conclude that the only means of establishing satisfactory relations between the carriers and those they serve is government ownership. If this more detailed and drastic regulation be not only adopted, but made effective, the ultimate result may be the same. For there are limits beyond which effective regulation cannot be carried without generating new evils for each it remedies. The public is naturally apt to think - as it usually has thought - that the new evils are due to inadequate, not to excessive, regulation; and, instead of ameliorating its policy, probably would make it more restrictive and burdensome. The result would be that, in course of time, we would have public management of private property.

Now, while public regulation of private property may succeed, public management of private property could not. It would involve divided responsibility of the worst form. There would be incessant struggles between the officers selected to represent the owners, seeking to recover the authority they had lost, and the regulating authori- 
ties representing the public, seeking to keep and increase the authority they had gained. Each side would exert itself more to nullify the work of the other than by its own policies to get good results. The rates made, the facilities furnished, the service rendered, would, while this conflict was on, go from bad to worse; and neither the public nor the owners could fix the responsibility, or hold accountable those responsible. The public authorities would assure the public that they were due to the realcitrancy, incompetency and want of public spirit of the railway officers; the railway officers would tell the owners of the railways that they were due to the meddlesomeness, the ignorance and the incapacity of the public authorities - and each probably would be half right. The capital needed for adequate development and extensions would not be forthcoming; for the public could not lay it out so long as the ownership of the roads was private, and private capitalists would not-probably could not-supply it while the management was public. ${ }^{1}$ The resulting conditions

1 "We can provide by legislation the sort of cars which a railroad shall use and the rates which it shall impose; we cannot by legislation force one single dollar of private capital into a railroad investment against its will.

"This phase of the matter is too little considered. If this government hopes to continue its present system; if we are to look in the future as in the past to private capital for the providing of our railroad transportation, it is fundamentally necessary that confidence in the fair treatmont of 
would be intolerable; and both the owners of the railways and the public might throw themselves into the arms of government ownership as the only haven of escape.

So, if the owners and managers of the railways, and the public, desire to avoid government ownership it behooves the former to give to the public everything to which it is entitled, and to do it public-spiritedly, diplomatically, honestly; and it equally behooves the public to exercise self-restraint, and act in a spirit of justice, according to the owners and managers reasonable freedom of action in the management of the properties, and the opportunity to earn and enjoy reasonable profits.

If only the salutary solution of the railway problem depended on the dealings of the public and the railways with each other, the importance of the nature, and the results, of their dealings would be great. But much more is involved. The development of large railway corporations and combinations has been contemporaneous with the development of equally large industrial corporations and combinations. It is often said that the reason why it is right and expedient for the public to regulate railways is that they are quasi-public cor-

that capital shall be established." From an address on "Transportation" by Commissioner C. A. Prouty, of the Interstate Commerce Commission, at Sheffield Scientific School, Yale University. 
porations; that they exercise the power of eminent domain, and render a public service. But this explanation is purely juridical. It merely tells why the government legally can regulate railways-not why it should and does. That it can do so is no reason at all why it should do so. The only sound reason why it should do so is that the public welfare requires it; and the public welfare requires it, not because the railway exercises the power of eminent domain, not because it is engaged in a public service, but because it is monopolistic in its nature and has a relation to industry and commerce that enables it, if improperly managed, to do measureless evil.

Now, recently many concerns which are not in the technical legal sense engaged in rendering public services have got more nearly complete monopolies of their lines of business than is possessed by any railway or combination of railways. It may be that their monopolistic size and power will be temporary. It is more probable they will be permanent. If they are there will be as good reason for extending public regulation to them as there is for subjecting railways to it. The first steps in this direction have been taken by the creation of the Bureau of Corporations, by the passage of the Sherman Antitrust Law, the corporation tax law, the meat inspection law, ete. The nature and the results of the regulation applied to railways inevitably will largely determine the na- 
ture and the results of the regulation applied to large industrial corporations. And there is just as much reason to bulieve that the success or failure of the regulation of large industrial corporations will determine whether their businesses shall be taken over by government as there is for believing that the success or failure of the regulation of railways will determine whether they shall be taken over. Therefore, the policy of railway regulation adopted, and its results, are apt to play a very important part in settling whether this country shall in course of time-perhaps in course of a comparatively short time-become a social-democratic state. This may appear to some an extreme view; but it is hard to see how it can be so regarded by those who realize the industrial revolution that has taken place in the United States in the last quarter century, and the change in public sentiment which has accompanied it and is still going on, regarding the proper form and functions of government.

The problem of how the railways ought to be regulated probably would be advanced a good way toward solution by settlement of the question of who shall regulate them. Heretofore each railway doing an interstate business has been subject to regulation by both the federal and state governments. The laws passed by Congress and the state legislatures, and the orders issued by the various commissions, have been usually inconsis- 
tent and often directly conflicting, and large railways subject to the laws not only of the federal government but of a number of states, often have found it practically impossible to obey them all. Most persons who have given the matter much thought believe it would be better for both railways and public if practically exclusive control were vested in the federal government. That this would have been done by the framers of our national Constitution, if they had foreseen present conditions, seems most probable.

A good many years ago Judge Cooley, the first chairman of the Interstate Commerce Commission, and one of the greatest of American jurists, said: ${ }^{1}$

It may be that by and by the general government, surveying the field of interstate commerce and taking note how state commerce encroaches upon and intermingles with it, crowding it in the same vehicles on the same roads, sharing with it the same expenses, rates which are imposed upon the one necessarily affecting rates which can be accepted on the other, and being handled at the same time by the same hands, under the same official control, will come to the conclusion that separate regulation of state commerce must necessarily be, to some extent, at least, and may be to a large extent, inconsistent with complete federal regulation of the commerce that is interstate. Should this conclusion be reached the federal legislature is not

1 "Comparative Merits of Written and Prescriptive Constitutions," 2 Harvard Law Review, 341-357. 
unlikely to take unto itself complete regulation of the whole.

The Constitution of the United States expressly confers on Congress authority to regulate commerce among the states. The courts long since held that any state law or regulation expressly intended to regulate interstate commerce, and having that effect, violated this constitutional provision. Suppose, however, that a state law purports to be intended, or, indeed, is intended, solely to regulate commerce within a state. Can it ever produce such effects as to make it conflict with the federal constitution?

This question has recently, for the first time, been directly presented to the federal courts, and passed on by one of them. The state of Minnesota fixed passenger and freight rates for transportation within its boundaries which were lower than the corresponding rates between points within the state and points outside of it. The effect was to compel the railways to reduce their interstate rates; for if they did not, shippers could ship and travelers could travel to the border of the state on the low state rates, and then reship from there, or purchase new tickets there, thus getting the benefit of the lower state rates on what were really interstate shipments and trips. Furthermore, for the railways to have charged lower rates on state than interstate commerce, handled under similar 
conditions, would have been an unjustifiable discrimination against interstate commerce. The railways, therefore, contended that the laws and regulations of Minnesota directly and necessarily interfered with interstate commerce and were unconstitutional. Judge W. H. Sanborn of the United States Circuit Court for the district of Minnesota, in a momentous decision, sustained this contention, ${ }^{1}$ saying that any state regulation which directly and necessarily interferes with interstate commerce is an encroachment on the exclusive authority of Congress to regulate commerce among the states, and therefore null and void. If the Supreme Court of the United States sustains this decision it will narrow and limit the power of the states to regulate even state commerce. It is hard to see how the Supreme Court can do otherwise, for to let the states continue to regulate railway

${ }^{1}$ Judge Sanborn summed up his conclusions in the following words :

"No case has been found in the books in which the facts disclose a more substantial burden imposed upon interstate commerce by the acts or orders of the officers of any state than that which the effect of the necessary operation of these acts and orders entails upon the interstate commerce of these companies. If, in the early proceedings in the Northern Pacific case, the Supreme Court was moved to say of the issue whether the necessary effect of these acts and orders was to interfere with and regulate interstate commerce, 'the question is not, at any rate, frivolous,' how, now, that their necessary effect upon that commerce has been indisputably proved to be not only general and substantial, but controlling, may they escape the ban of the $2: 31$ 
operation and rates without regard to the laws passed and the rates fixed by the federal government would be to let them largely or wholly nullify the policy adopted by the nation.

While the Supreme Court may hold that where a state law or regulation necessarily interferes with ol nullifies a federal law or regulation the former must yield, it is not at all probable- nor, perhaps, is it desirable - that the states will be prohibited from making any reasonable regulations which do not directly interfere with interstate commerce. Congress, then, by setting a good example, and firmly limiting the activities of state legislatures and commissions, can foster a railroad policy that will benefit both the carrier and the public.

Another phase of the question of who shall regulate is whether it shall be done by the law makers directly or through commissions. The nation

Constitution? If one state might by such radical reductions of its local fares and rates below legal and interstate fares and rates constitutionally use the laws of trade and the prohibition of discriminations in the interstate commerce law to force like reductions of interstate rates, all states might do so, and the power of the states to regulate fares and rates in interstate commerce would be supreme and that of Congress and the Interstate Commerce Commission inferior and futile. Such does not seem to be the law.

"Each of the acts and orders challenged has the natural and necessary effect substantially to burden and directly to regulate interstate commerce, to create undue and unjust discriminations between localities in Minnesota and those in adjoining states, and it is anconstitutional and void." 
has had since 1887 an Interstate Commerce Commission whose powers were greatly enlarged by the Hepburn act of 1906 and by the Mann-Elkins act and other legislation in 1910. There are also 43 state commissions. We have wisely adopted the theory that so difficult and technical a subject should be dealt with by a small body of experts in practically continuous session. Unfortunately, the state legislatures, while abstractly indorsing this theory, often cannot be got to act conformably with it. During recent years, in all parts of the country, they have constantly interfered with work they had previously delegated to the commissions. For example, repeatedly, after having given the rate-regulating power to commissions, they have stepped in and themselves fixed rates, sometimes against the open opposition of the commissioners who had been chosen as the most competent persons to do this work. If railroad commissions are to command the respect of railroads, shippers and the public, if they are to perform their duties fairly, intelligently and beneficially, they and their work must be left as free from legislative interference as are the courts and their work.

It is, however, far from enough to make their labors effective, just and beneficial, for them to be given ample power and left to exercise it without undue legislative interference. Their personnel is of the first importance. Their members 
should be men of great ability. They deal with matters vital to the welfare of the country; and only men of first rate ability can properly deal with such things. They should be impartial and disinterested. Only men who are not only able but also impartial and disinterested, can command the respect of railway managers, shippers and others directly concerned; and that they should command respect is as important as that they should have the naked legal power to compel acquiescence in their views. They have to settle questions, all of which are somewhat technical, and many of which are very technical. They should, therefore, have a special knowledge of these matters when chosen, or at least should be allowed to hold office long enough to acquire such knowledge, and after having acquired it to use it for a substantial period in the public service.

The Massachusetts Commission has never possessed extensive legal powers. Yet no commission ever has done work at once so efiective and so salutary as the Massachusetts Commission did in its early history. This was because it was dominated by a man having in preëminent degree all the qualifications mentioned-Charles Francis Adams. As Dr. Hadley has said: ${ }^{1}$

This absence of specific powers was just what $\mathrm{Mr}$.

"“Ethics of Corporate Management," North American Review, January 18, 1907. 
Adams welcomed. It threw the commission back on the power of common sense-which does not seem as strong as statutory power to prosecute people and put them in prison, but which, in the hands of a man who really possesses it, is actually very much stronger. ${ }^{1}$

The personnels of most railway commissions have fallen, and still fall, grievously short of the requirements. About three years ago I made a study of the state commissions as then constituted. ${ }^{2}$ The principal points covered were whether the commissioners were elective or appointive, their previous occupations, the annual salaries paid, the terms for which they were chosen, and the number of years each had served. I secured these data concerning 40 state commissions and the Interstate Commerce Commission. Of the 124 members of state commissions only 13 were former railway officers or employees. None of these had held a higher railway office than that of auditor or assistant general superintendent; most

'Dr. Hadley adds: "And when commissions of more recent years, disregarding the experience of Mr. Adams, have besought over and over again for an increase of their power to make rates, and their power to prosecute offenders, and their power to keep the courts from reviewing their acts, I am reminded of the minister in the country church, who said: 'O Lord, we pray for power; O Lord, we pray for power,' until an old deacon, unable to contain himself, interrupted. ' 'Tain't power you lack, young man, it's idees.',

"Railway Age Gazette, January 15, 1909 ; pages 99 and 123. 235 
of them had been conductors, telegraph operators, road-masters, etc.; and despite the fact that their most important work is to regulate rates, but one had ever had any experience in the traffic depart. ment of a railway or an industrial concern.

The number of lawyers on the commissions, 42 , was much larger than the number of men from any other vocation. Many of these, as active politicians, had energetically participated in agitations against the railways. The previous occupations of other members of the state commissions were reported as follows: Business men, 5 ; merchants, 3 ; cotton factors, 2; real estate dealers, 2; insurance agent, 1 ; mine operator, 1 ; engineers, 3 ; railway contractor, 1 ; farmers, 12 ; manufacturers, 5; lumberman, 1; newspaper men, 2; transfer man, 1; physician, 1 ; assistant secretary $\mathrm{Mu}$ nicipal Art Commission, 1; assistant secretary Interstate Commerce Commission, 1; state land agent, 1 ; bankers, 6 ; coal operator, 1 ; teacher, 1 ; economist, 1 ; commissioner, 1 ; sheriff, 1 .

The commissions, it will be seen, contained a large number of manufacturers, merchants, farmers and other shippers, and a comparatively small sprinkling of former railway officers and employees. Their main duty is to arbitrate between shippers and railways. A shipper who becomes a railway commissioner is apt to have a leaning in favor of shippers, just as a railway man who becomes a commissioner is apt to have a leaning in 236 
favor of railways. However upright the intentions of the state commissions, the previous occupations and affiliations of most of their members gives them a bias, conscious or unconscious, against the railways; many are, in effect, packed courts.

Experience has shown that the fittest men will be secured when the commissions are appointive. In one state whose commission is appointive the governor named a leading lawyer, a distinguished professor of political economy and an expert statistician who was also a good economist. In a state having an elective commission the people chose at about the same time as two of the commissioners a cowboy who had "killed his man" and who, since his election, has been arrested for threateningly flourishing his gun in public, and a man, who, a short time before, had bought a gold brick for $\$ 10,000$. In another state the people elected and have since reëlected to the railroad commission a man whose only claim on their suffrages was that while a railroad brakeman he had lost both his legs in a railroad accident. Cowboys, purchasers of gold bricks and crippled brakemen are not the kind of men who will solve the problem of fair and salutary regulation of railways. While experience has shown that the better commissioners are secured by appointment, of 40 commissions in 1909, 22 were elective and 18 appointive. 
The holding of public office, to our discredit, is not regarded as so much of an honor here as in Europe. To get men of ability to enter the public service it is usually necessary to pay them substantial salaries. The average salary of the chairmen and members of the state cornmissions in 1909 was about $\$ 4,000$ a year. As low as this is, considering the importance of their duties and responsibilities, it is misleadingly large. For the 10 members of the two New York commissions get salaries that aggregate $\$ 150,000$ a year, which would furnish salaries at $\$ 4,000$ a year for $37 \mathrm{com}$ missioners. The large salaries of the New York commissioners greatly raise the average. The salaries range from $\$ 15,000$ in New York to $\$ 1,200$ in North Dakota. Twenty-four states pay less than $\$ 4,000 ; 19$ pay $\$ 3,000$ or less; 12 pay $\$ 2,500$ or less; only 6 pay $\$ 5,000$ or more.

The commissioners are chosen for terms of two to six years, the average being four years. The average time that had been served by the commissioners when I made my investigation was three years. The average service of the incumbents was less than the average length of the legal terms not only because changes in the personnel of the commissions are frequent, but also because a number of commissions had recently been created. That the practice of constantly changing commissioners continues, however, is shown by the fact that within two years after my anal- 
ysis 38 changes had been made in the personnel of the 40 commissions included in it.

Next to choosing experts to do difficult and important work the best way is to keep at work those chosen until experience makes them experts. We do neither. A man of good ability would have to work hard to get reasonably familiar with any one of the leading branches of the railway business in the average time that the state commissioners serve; and they are charged with the duty of regulating not merely one branch, but all.

The facts about the Interstate Commerce Commission are widely different. Its members are appointed for seven years and often reappointed. They are paid salaries of $\$ 10,000$ a year. Most of them have been men of good, and some of them of great, ability. The two members last appointed had served as chairmen of state commissions, B. H. Meyer in Wisconsin, and C. C. McChord in Kentucky. Professor Meyer also long has had an international reputation as an authority on railway economics. Unfortunately, very few of the commissioners have, like Professor Meyer and Mr. McChord, acquired, previously to their selection, either in or out of the railway business, any special knowledge of or qualifications for their duties. They usually have been lawyers and commonly have been chosen, retained and'retired largely for political reasons. Owing to these and other causes it must be regretfully said that many persons, in- 
cluding most railway officer's, lack full confidence in the Commission's expertness and impartiality. Most of its members have been wanting in what Dr. Hadley called the "ethical influence" exercised by Charles Francis Adams when he was on the Massachusetts commission. They have not got their important recommendations adopted by the railways, as $\mathrm{Mr}$. Adams did, "without any authority except the authority of common sense." They have constantly sought and obtained increased statutory authority.

As Dr. Hadley has remarked, when you increase the powers of a commission you often reduce its power. When it has numerous specific statutory powers it is apt to resort to their constant coercive exercise instead of taking the slower course of trying by logic to convince that the changes it favors should be made, and by moral influence to get them made merely because they are right. Changes wrought by the exercise of statutory power may be more numerous and often quicker; but changes effected by the pressure of logic and moral suasion are much surer to be true and lasting reforms.

James Madison, writing in The Federalist in advocacy of the adoption of our federal constitution, ${ }^{1}$ said :

The accumulation of all powers, legislative, executive ${ }^{1}$ The Federalist. No. XLVII. 
and judiciary, in the same hands, whether of one, a few or many, and whether hereditary, self-appointed or elective, may justly be pronounced the very definition of tyranny.

Now, this accumulation of legislative, executive and judicial powers has been made in the hands of our state and interstate railway commissions; and the real shortcomings which the commissions have, and the additional more or less imaginary shortcomings which many think they have, are undoubtedly very largely due to this. It is the function of the legislative department to make the laws. The courts have held that the fixing oi rates to be charged by a public service corporation is a legislative act which may be performed by the lawmakers themselves or delegated by them to a commission. This power Congress and the various legislatures have delegated to the railway commissions. The courts have held that the determination of the reasonableness of rates is a judicial function; and this power has been given to the commissions. The enforcement of the laws is an executive function; and the authority and the duty to enforce the laws regarding railways have also been given to the commissions.

The most serious incompatibility between their functions is that between their executive and their judicial duties. The Interstate Commerce Commission may be engaged at one hour in the $2+1$ 
executive work of enforcing the laws regarding rebating, the equipment of engines and cars with safety appliances, or the inspection of locomotive boilers; or appearing as the defendant in a suit brought to set aside one of its orders. It may in the very next hour turn to its most important work that of arbitrating between shippers and railways regarding the reasonableness of rates. The railways whose rates are in question may be the very same against which the Commission, in the performance of its executive duties, has just been starting prosecutions. Or they may have just made the Commission the defendant in a proceeding to set aside some order issued by it. Now, it is not human nature for men to treat entirely without prejudice those who resist or try to restrict or overthrow their authority, or whom they regard as guilty of violations of the law and against whom they have just set it in motion; the detective does not look with impartial eye upon the suspect, or the prosecuting attorney on the prisoner at the bar, however conclusively he may subsequently prove his innocence; if they did they would be inefficient detectives and prosecuting attorneys. But railway commissioners are human. There is always, therefore, very serious danger that the commission will be haunted in its task of determining the reasonableness of rates by a bias against the carriers generated by its activity in enforcing the laws. This has been most 
clearly conceded and expressed by one of the ablest, fairest and most experienced members of the Interstate Commerce Commission. In a speech before the American Bar Association at Portland, Maine, in August, 1909, Commissioner Charles A. Prouty said:

It has been in the past one of the most serious reproaches against that act [the act to regulate commerce] that the Commission was made by its terms at once a prosecuting officer and judge . . . It is commanded to enforce the provisions of the act to regulate commerce. . These duties are largely executive. They can best be discharged by a single head responsible to the executive and answerable to the spur of popular criticism. Second, this Commission is in essence a judicial tribunal which hears and decides complaints. The qualifications of such a body are the exact opposite of the other. . . . I very much doubt whether the same body can properly discharge both these functions. In the end it will either become remiss in its executive duties or will, in the zeal of those, become unfit for the dispassionate performance of its judicial functions.

He therefore advocated relieving the Commission of all its duties except the determination and fixing of reasonable rates.

The federal bureau of corporations has been created to collect and furnish to Congress and the executive departments information about corporations engaged in interstate commerce which may 
le useful in framing and enforeing laws for their regulation. It could perform the same duty with respect to interstate railways better than can the Interstate Commerce Commission. The federal department of justice exists solely to enforce the federal laws. It could perform this duty with respect to the railways better than can the Commission. It would, therefore, be natural and logical to transfer these duties to the bureau of corporations and the department of justice. This would relieve the Commission of many of the tasks which have been heaped upon it in such numbers that it has become hard for its members, however zealous and laborious, to carry them. It would give it more time for its vitally important duty of regulating rates. It would remove it from an atmosphere in which it is impossible for it to keep its mind entirely clear of prejudice and bias. It would not only tend to keep the Commission impartial, but it would tend to keep railway men from thinking it is not so; those who have just smarted, whether rightly or wrongly, at the hands of a prosecutor cannot, if at the next minute haled before him in the rôle of a judge, think him unbiased in his attitude toward them. And next to having just judges it is most important to the effective and wholesorne application and enforcement of the laws that those within their jurisdiction shall consider them just. Such a change would do much to make federal legislation more effective, and more 
fair and salutary; and similar results would be produced by similar legislation with respect to the state railway commissions. ${ }^{1}$

'It may, perhaps, be said that a step toward separating the executive and judicial functions heretofore belonging to the Interstate Commerce Commission was taken by the creation of the Commerce Court. But the Commerce Court has not been given any of the duties heretofore performed by the Commission. It simply has been substituted for the United States Circuit Courts as the body to which appeals shall be made in certain cases-mainly rate cases-from the Commission. Its creation does not even seem adapted to make regulation much, if any, more expert. Its members are to serve only for a maximum period of five years, after which they must be transferred to the regular circuit bench. This is not long enough to get an expert knowledge of railway affairs. Under the laws as they now stand, however, appeals to the Commerce Court may involve mainly questions of law. The Commission's findings of fact may usually be accepted as final. The Commission has somewhat the same relation to the Commerce Court that a jury has to a court of equity which refers to it questions of fact for determination. That the Commission is concerned mainly with the determination of facts does not, however, make it any less necessary that it should be impartial. We do not think that because juries deal only with questions of fact it is less necessary that they should be impartial than it is that the judges should be. 


\section{CHAPTER XII}

\section{GOVERNMENT REGULATION : UNDERLYING PRINCIPLES}

THE exact matters to which government regulation should relate, and the exact form regulation of each matter should take, are very difficult questions. There are, however, certain underlying principles whose soundness is not successfully impeached because nowadays they are apt to be more honored in the breach than in the observance. One of these is that the sole proper aim of regulation is the promotion of the public welfare--the furtherance permanently of "the greatest good of the greatest number." Sometimes regulation has the direct effect of benefiting some particular class; as railway employees, by limiting the number of hours a day they may be required to work; or shippers, by reducing the rates that they must pay; or railways themselves, by prohibiting the giving or receiving of rebates. If the benefit conferred on the special class is not the only end attained, but is merely incidental to the seeking and attaining of some object beneficial to the public as a whole, the regulation is just and proper. But if the only effect of a particular regulation is 
to benefit one class at the expense of another, or at the cost of the public, it is entirely unjustiniable. If any species of regulation will benefit the public in the long run it ought to be adopted no matter what class it will hurt. If it will not benefit the public in the long run it ought not to be adopted no matter what class it will help.

We have had much discussion of the extent of the power to regulate, and many seem to think that if it can be shown that any measure proposed is within the limits of national or state authority that is sufficient reason for its enactment. But whether the government has the power to do a particular thing, and whether the power's exercise will benefit the public, are two different questions. If the federal and state Constitutions have withheld from Congress and the legislatures any powers that ought to be exercised for the public benefit, whether for the regulation of railways or any other purpose, they ought to be amended; and if the Constitutions have granted any powers whose exercise would not be for the benefit of the public those powers ought to be left dormant. Congress and the legislatures could levy heavier taxes than they do. The power to tax is practically unlimited. That is not considered sufficient reason for exercising it without limitation.

Another principle of great importance is that generally government regulation of business should prescribe the ends to be attained, but not the 247 
means by which they shall be attained. Public authorities are the most competent to say what results railways, for example, should secure for the public. They are seldom so competent as the men actively engaged in the business to say how those results should be secured. Public regulation should be supervisory, not managerial. Its function is to see that the directors and officers do their duty, not to supplant them in doing it. The Interstate Commerce Commission, composed of seven men, can exercise effective and salutary supervision of railway management. But if its members, either because of greed for power or of requirements of the law, seek to constitute themselves the general managers and traffic managers of all the railways, the railways will be neither well regulated nor well managed, nor the public well served.

The railways will not be well regulated because the regulating authorities will neglect their proper regulating function; and they will not be well managed because the managers will be engaged in scuffling with the public authorities or carrying out their orders instead of devising and carrying out new methods for developing traffic or increasing efficiency. I am unable to believe that any seven men, however able and however clothed with statutory power-especially if they lack railway experience-can bring about as great improvements in railway operation as can all the railway managers and owners of the United States, 
if left a free hand, and the stimulus of the hope and expectation of gain.

Again, there are many things which railways, like all other persons, ought to do, but which they ought not to be required by law to do. The limits of wise public policy are not coincident with, but much narrower than, the limits of individual, or even corporate, moral duty. Anglo-Saxon governments have acted on the principle that it is safer to allow too much liberty than to impose too much restraint; and it is still as true as ever that there are many things that cannot be accomplished by law, and many others which can be accomplished but not without causing more evils than are cured.

The regulating laws should be clear, specific, consistent, mandatory. By "mandatory" is meant that they should imperatively require to be done just what it is intended shall be done. Administrative officers should be given little or no cliscretion to enforce or not enforce them. The Hepburn bill introduced in Congress in 1908 to amend the Sherman Antitrust law was typical of a class of measures which are becoming more and more common and which are the very kind that ought not to be passed. It provided that a railway which was a party to any agreement or combination with competing lines might file its terms with the Interstate Commerce Commission, and that body should determine by insinction of the papers 
whether the combination was reasonable or not, and, in its discretion, grant or deny the railway immunity from prosecution. As Judge Cooley has said: ${ }^{1}$

Security can only come from fixed rules which the people, as they become familiar with them, will habitually respect and observe; it cannot come from judgments which are directed by the individual will alone, every one of which must stand by itself on its own reasons, must be submitted to without question, and will be attributed to good motives or bad, to wisdom or malice, to judgment or passion, according to the views which are held by the people or by individuals concerning the ruler who gives it.

Administrative discretion is arbitrary discretion, and arbitrary discretion will be used, when public sentiment is hostile to an industry, to pursue it harshly and oppressively, and when public sentiment is friendly to it, to enforce the laws laxly and foster all manner of abuses.

It is comparatively easy to formulate correct general principles. It is harder to apply them to specific questions of policy. But their correct application and carrying out are much more important than their formulation. In previous chapters I have touched on regulation of various matters. No doubt, regulation should relate - as already it generally does relate - to three broad phases of the

'Cooley on "'Torts," page 10.

250 
railway business: (1) rates, (2) finances, and (3) operation.

\section{REGULATION OF RATES}

Methods of regulating rates vary widely. (1.) The state legislatures sometimes fix maximum schedules for all the traffic in the state. (2.) Some state commissions fix maximum rates for part or all of the state traffic. (3.) The interstate and some state commissions may either on their own motion or on complaint restrain advances in rates pending investigation, and after public hearing enjoin advances or require reductions. (4.) The commissions of some states can take action regarding rates only after formal complaint and hearing. (5.) In some states the commissions can only investigate rates and recommend changes; they cannot issue and enforce orders regarding them.

The question, whether the entire power of making rates should be given to the Interstate Commission, or their initiation should be left with the railways, the Commission being given authority only to correct the traffic manager's mistakes where his judgment goes wrong or he is prompted by bad motives, was discussed fully when the Hepburn act was pending. Public sentiment and Congress decided that the initiative should be left with the railways. This was in accord with the principle that public regulation should be supervisory, not managerial-that it should prescribe 251 
the duties of railway managers and hold them to their performance, not seek to perform them. It is quite generally believed that railway men are ordinarily best fitted by experience and training, and better situated, with their thorough knowledge of conditions along their lines, to say what rates ought to be and ought not to be than any other persons. Usually, also, they have good reason for making them fair and reasonable; for fair and reasonable rates foster commercial and industrial development; and this increases railway traffic and profits. Entire schedules of rates made by legislatures or commissions repeatedly have been held unconstitutional because the authorities, in their zeal to get something of importance done quickly, did not, by patient, thorough and intelligent investigation, ascertain what would be just as between travelers, shippers and carriers, and fixed rates so low as to be confiscatory. In other cases legislatures and commissions have made rates which were high enough, perhaps, to be not actually confiscatory, but so low as to discourage railway development, and, therefore, to be inexpedient.

While the Hepburn act authorized the Interstate Commerce Commission to reduce rates found excessive or unfairly discriminatory, it gave it, and the law now gives it, no power to raise a rate that is unfairly low. The Mann-Elkins act of 1910 also gives the Commission authority, in its discretion, 
either on its own motion or on complaint, to suspend for four months pending investigation of its reasonableness, any advance in interstate rates, and if the investigation be not finished at the end of this time, to suspend it for six months more. The practical effect is to deprive the railways of the initiative in advancing rates. The British Railway and Canal Commission some twenty years ago was given similar power. The result has been practically to prevent any advances since in railway rates in England. W. M. Acworth says it has also practically stopped reductions.

It is commonly assumed that railway traffic managers are always bent on maintaining and advancing rates, because high rates mean large profits, and that, therefore, government regulation is needful to keep rates low. This is but partially correct. The average rate per ton per mile in the United States in 1870 was 18.89 mills. In 1887, when the Interstate Commerce Act was passed, it had been reduced to 9.84 mills, or 52 per cent. Between 1887 and 1906, the latter the year the Hepburn act went into effect, it declined from 9.84 to 7.48 mills, or 24 per cent. Government regulation had almost no hand in the great and innumerable reductions prior to 1887 reflected in the decline in the average rate. They were made by the traffic managers of the railways. It had very little hand in the great and numerous reductions in the period 1887 1906. Practically all were made 253 
by the traffic managers. The traffic managers voluntarily made these reductions for two reasons. First, each of them sought, by lowering his rates, to capture business from competitors. Competitive ratemaking has now been greatly reducedalthough not wholly eliminated-by railway combinations and consolidations, and by legislation requiring the roads to publish all their rates, and to give 30 days notice of proposed changes. The second reason why the traffic managers reduced rates was that they hoped thereby to develop so much additional traffic that the net returns from it on the lower rates would exceed the net returns from a smaller traffic on the higher rates. But the traffic manager never knows when he makes a reduction whether the resulting increase in traffic will be large enough to enable him to derive a larger net return from it than he did from the smaller traffic on the higher rate. If it is not, the reduction in the rate will cause a loss instead of a gain, and he will desire to restore it. If he knows when the original reduction is proposed that if it turns out unprofitably he can later, if he chooses, put the rate back on the old basis, he will make the reduction; and if it turns out to be profitable the lower rate will, of course, be permanent. But if he knows that in case the reduction does not wove profitable he probably, when he attempts to restore the old rate, will encounter a restraining order, and that to get it restored he will 254 
have to go through months of litigation, which may finally be unsuccessful, he will not make the reduction unless he is morally certain that it will be advantageous to the road; and this moral certainty he seldom can have. Now, this is the reason why, as Mr. Acworth says, the exercise of the authority to prevent advances in rates in England has also prevented reductions; and for this same reason the exercise of the same authority in the United States may have the same result.

It may be said that if the traffic managers do not make the reductions they ought to, public authorities can and will. But no commission or legislature can constitutionally reduce a rate to a point where it would not, with present traffic be reasonably compensatory; the courts, in determining the reasonableness of rates fixed by public authority will, and, indeed, can take into consideration only the volume of traffic moved in the past and at present; and the most beneficial reductions are those which are profitable to the railway only because they increase traffic. Consequently, many of those who strongly advocated giving the Commission power to reduce any rate it found unreasonably high, and who would now give it authority also to raise any rate that it may find unreasonably low, still believe that, within these limits, it would be wise public policy to leave to the railways the initiative in ratemaking.

The underlying principles of ratemaking have 255 
been discussed in the chapters on "Principles of Ratemaking" and "Railway Discrimination." The regulating authorities sometimes cannot fix rates in the same way that the traffic manager can. As the Supreme Court of the United States said in one case: ${ }^{1}$

"What the company may choose voluntarily to do furnishes no criterion for the measurement of the power of a legislature. Persons may voluntarily contract to do what no legislature would have the right to compel them to do."

The traffic manager of a railway may reduce a rate much below what, with the existing traffic, would be compensatory in the hope and expectation that the reduction will cause such an increase in traffic as to increase earnings. As I have already pointed out, a commission or legislature cannot do this. But, broadly speaking, the principles which ought to guide the traffic manager in making rates, are the same that should guide a commission in regulating them. Each should fix them with a view to the various conditions which determine the cost of the transportation service to the carriers that render it and its value to those that receive it. Any adjustment of rates that would be unfair to a shipper or a community or to the owners of the railways, if made by their traffic

'Lake Shoje \& Michigan Southern R. R. Co. vs. Smith, 173 U. S., 684, 697. 
managers, would be equally unfair if made by public authorities. It may be that under government ownership it might be equitable and desirable in some cases to make rates in a different way from that in which a fair and enlightened traffic manager will make them under private ownership; but so long as, while the service of the railways is public, their ownership continues to be private, there can, it would seem, be no difference between the way that a fair and enlightened traffic manager would make rates and the way that a fair and enlightened commission would make them. Indeed, it is impossible that under public regulation there should permanently obtain any substantial difference between the way that rates are made by the traffic managers and by public authority. For such is the relationship between and interdependence of rates, not merely in the same territory, but in all parts of the country, that a commission cannot establish the rule according to which a single rate or schedule of rates shall be made without thereby establishing the rule according to which innumerable other rates which it has not touched shall be made; and after it has fixed a substantial number of rates in all parts of the country, it has fixed the basis on which the vast majority of all rates must be made. 


\section{REGULATION OF FINANCES}

The second phase of the railway business to which regulation relates is finance. Every time a rate is fixed by public authority, or a law is passed, or an order issued by a commission, regulating the operation of railways, their earnings are affected. I have discussed in other chapters the amount of profit that they should be allowed to earn. That question should not be determined with reference solely to the circumstances that they are public service corporations, and exercise the power of eminent domain, and that therefore the public may deal differently with them than with concerns engaged in a private calling. It is essentially a question of public expediency. Railways compete in the money market with manufacturing, mercantile and other concerns for capital. Capital is invested where, with allowance for differences in risk, it can get the largest return. The fact that a railway is a public service corporation, and exercises the power of eminent domain, adds nothing to its credit when it seeks to sell its bonds and stocks. The only thing that influences the investor is the prospect of return; and if the probable return in any line of business is by public regulation or otherwise made less than in other lines the amount of capital put into it will be inadequate.

Doubtless there should be some public regulation of the security issues of railways; but the true 258 
ground for this is not the one usually advanced. It usually is advocated on the theory that when railways are overcapitalized they charge excessive rates in order to earn dividends on their watered stocks. If all the railways in any section or in the country were overcapitalized this might be true; but while there are not a few roads in the United States that are overcapitalized there are in every section more that are not; and if the overcapitalized roads raised their rates, while the other roads did not, they would not increase their earnings, but would drive business to their competitors, and reduce them. ${ }^{1}$

The true justification of public regulation of railroad securities is that it is needed to insure good transportation and protect investors. There is always danger that an overcapitalized company, to keep up the price of its securities, will pay out in interest and dividends what ought to be spent in maintaining its property. The Interstate Commerce Commission, with authority given by the Hepburn act, required the railroads to begin the use, on July 1, 1907, of a uniform system of accounting. In several states similar accounting systems have been prescribed. These systems may be defective in details; but they are a step in the right direction. To prevent railroads from being loaded with debt, plunged into bankruptcy,

1"'Railroad Administration,", by Ray Morris, page 216. 
and rendered incapable of performing properly their duty to the pullice, regulation should, perhals, be exereised in future over their issues of bonds and other evidences of indebtedness. It ought, if practicahle, to he seen that every dollar raised by the side of either stocks or bonds goes into the development and improvement of the property, and not into the pocket of some one having no claim to it. The looting of railroads should be guarded against and punished like the looting of banks. Whether any steps, except those necessary to accomplish these purposes, should be taken is a question regarding which there are wide differences of opinion.

A law of Massachusetts provided for fifteen years that securities might not be issued except at their market value; what this value was being determined by the State Railroad Commission. Sometimes after the Commission had fixed the nominal market value the actual market price declined and the road had left a lot of unsalable securities. And when the commissioners fixed the price at which securities should be sold it gave investors a sort of guarantee of the state that the price fixed was their value. The state was, thereby, it has been contended, morally obligated to make no reductions in rates that would impair their value.

Texas prohibits the issuance by any railway of stocks and bonds of a par value of more than 50 per cent. in excess of the value of its property as 
determined by the State Railroad Commission: and the commission has fixed the "true value" of Texas roads at only forty-eight per cent. of their capitalization, and a little less than the amount of their outstanding bonds, thereby making the issue of new securities by some railways impossible.

Railroad officers and competent students contend that the administration of these statutes has hindered railroad development; ${ }^{1}$ and the legislature of Massachusetts, in 1908, amended the law in that state so as to provide that the stockholders of railways may fix the price at which the stock shall be issued, and that the Railroad Commission may refuse its approval only if in its opinion "the price fixed by the stockholders is so low as to be inconsistent with the public interest."

New York and Wisconsin have statutes giving their state commissions power to regulate security issues. That of New York provides that securities may be issued only for the acquisition of property, the construction of new, or the permanent improvement of old, lines, or the refunding of outstanding obligations; and permission to make issues must be secured from the proper state public service commissions.

Commissioner Franklin K. Lane of the Interstate Commerce Commission has advocated legislation by Congress (1) specifying the purposes for

1"Railroad Administration," by Ray Morris, page 221. 18 
which railway bonds and stocks may be issued; (2) requiring a majority of the directors of a railway, when securities are to be issued, to subscribe on the corporate minutes to a full statement of the purposes for which the money is to be used and send a copy of the statement to the Interstate Commerce Commission; (3) requiring the directors to make an annual sworn report to the Commission of how securities were sold, the proceeds and their use; and (4) making it a criminal offense for directors to issue securities for any purpose not authorized by law, or to spend money realized from them for any purpose but that for which it was originally declared it was to be raised.

Probably the main defect of much of the past legislation upon this subject has been that in one way or another it has divided the responsibility for wise and honest financial management. The directors of a railway are its responsible managers. They owe duties to both their security holders and the public. Their duty to the public is to furnish good service at reasonable rates. Their duty to the holders of their securities is to get for them the largest return compatible with the rights of the public. Any law that gives a railway commission power to control the directors in the issuance of securities transfers part of the responsibility for what is done from the directors, who should know thoroughly the conditions and needs of the corporation, to the commission, which must 
know less about its conditions and needs. If the directors act unwisely or dishonestly, and the commission-whether through ignorance or guilty knowledge-permits their act, the directors can defend themselves by saying the commission approved. In this way such legislation may be a cloak for and an incentive to corporate mismanagement. If the directors attempt to do something that ought to be done and the commission thwarts them, stockholders and public are harmed, and government regulation is discredited.

It would seem that, instead of thus dividing the responsibility, regulatory legislation should fix it upon the directors so clearly and firmly that it could not be shirked or evaded. Lawyers know best how hard this is to do. The statutes and reports are full of laws and decisions of the courts defining minutely the duties of directors of corporations and the remedies of public and stockholders for their misfeasances. But the cunning of directors in devising means of prostituting their trusteeship has constantly outstripped the energy and ingenuity of legislatures and courts in devising means of preventing, detecting and punishing their offenses. However, legislation by both the nation and the states, such as is suggested by Mr. Lane, might usefully supplement existing statutes and decisions of the courts regarding the duties and accountability of directors.

The fundamental purpose of all legislation to 2633 
control issues of securities should be to get all the money derived from them spent on permanent inprovements or additions to the property. The good of the property is, in the long run, the good of stockholders, creditors and public. But the value of railway property, like that of other property, is not increased alone by expenditures on it. It is increased, for example, by advances in the value of land used for right of way and terminals. Should legislation such as Mr. Lane proposes permit such increment in the value of railway property to be capitalized? Under the New York law it could not be. But if railways are not allowed to capitalize this increment, or to earn what will include a fair return upon it, as well as on their cash investment, will they not be put at a disadvantage in competing for new capital against concerns that are allowed to capitalize their increment, and also be denied their right, as defined by the Supreme Court of the United States, to earn a "fair return" upon the "fair value" of their property?

My own view would be that, in a broad way, future legislation should, like the New York law, let only actual investment in permanent improvements or additions be capitalized, but that it will be desirable to allow railways to earn such a return on the increment in value of their real property as will make investment in them as attractive as in other concerns. 
Should directors be allowed to invest money derived from capital issues in stocks to get control of competing lines? This is a question that legislation should definitely settle. The trend of economic opinion is rather favorable to railway combination under public control; but public opinion and existing laws are distinctly hostile to whatever restricts competition. The federal and state governments should either frankly permit combination or effectively condemn it; they should not go on ineffectively prohibiting it.

The proposition to make directors record and report what securities are to be issued for is unassailable. Stockholders and public have a right to know this. But is it practicable, as Mr. Lane suggests, to require the directors to spend money only for the purpose originally stated? Directors are not omniscient. Sometimes they might honestly raise more money for some purpose than proved to be needed; sometimes they might need immediately to spend money for capital account that they could not get promptly. In the former case they would have raised money that they could never spend for any purpose. In the latter they would need money that they could not raise.

The plan should be broadened to take in such cases. Probably it should be amended to provide that if the directors raised more money for any purpose than proved to be required, or needed for some immediate purpose capital that had not been 
raised for that purpose, they might, with the approval of the proper state, or the Interstate, Commission, apply receipts from securities to objects for which the securities were not issued.

As already said, the main aim of legislation should be to compel every dollar derived from securities to be honestly spent in construction, additions and improvements. The best means to this end is to define the duties of directors in this regard and to provide for such publicity for their acts and such penalties for violations of the law that evasion of their proper accountability will be practically impossible.

Under the proposed legislation they would have to give publicity to their acts themselves, and if they made false statements the special examiners of the Interstate Commerce Commission, who have lawful access to all railway books and papers at any time, would probably detect the fact, and both publicity and punishment would follow.

The proposed legislation probably will be criticised because it would not prohibit the sale of new stocks and bonds below par. But such a prohibition by the nation, or by the less developed states, would be a serious obstacle to the construction of new lines by any but established railways. New independent lines seldom or never pay at first. By buying their securities below par investors discount the losses they anticipate during the youti of the enterprise. If the securities could not be 260 
sold at a discount they usually could not be sold at all. If, after every dollar derived from them has been honestly spent in construction and additions, securities of new lines sold below par shall rise in value to par or higher, the owners probably will be no more than compensated for the risk taken and the early losses suffered. As for the old, prosperous roads, there would be little incentive to watering their stock if it were known that every dollar realized from the added securities would have to be spent on the property. ${ }^{1}$

${ }^{1}$ The Railroad Securities Commission, whose report to President Taft was made public after the text was put in type, favored a policy in dealing with the issuance of railway bonds and stocks similar to, although more conservative than, that I have advocated. As the Commission said: "Many, if not most, of the abuses connected with railroad securities arise out of an almost universal failure to recognize distinctions which exist and should exist between bonds and stocks. A bond is an obligation to pay a fixed sum of money at a stated time. A stock certificate is merely the evidence of ownership of a share in the property, profits and risks of a corporation... The real value of the stock certificate depends upon the manner in which the money has been invested." The Commission, therefore, expressed itself as "of the opinion that it is far more important to ascertain just what are the facts connected with the issue of securities and what is actually done with whatever money has in fact been realized from the stock which is issued, than merely to make sure that the par value of the stock was paid in at the time of issue." The Commission said that if rates were to be materially influenced by the amount of the outstanding securities it would be desirable for securities to be issued under governmental regulation, 267 


\section{REGULATION OF OPERATION}

Railway managers sometimes have protested against public interference with the physical operation of the roads. Regulation of physical operation is perhaps more desirable and justifiable than any other kind. The primary duty of public carriers is to furnish safe and adequate transporta-

but it believed "that the amount and face value of outstanding securities has only an indirect influence on the making of rates, and that it should have little if any weight in their regulation." "If," the Commission added, "railroad securities were to be issued only after express authorization of each particular issue by the Interstate Commerce Commission or other governmental agency, it is difficult to see how the government could thereafter escape the moral, if not the legal, obligation to recognize these securities in the regulation of railload rates," and "the possible consequences of such a system are too serious to warrant its adoption at the present time." The Commission, therefore, confined itself to recommending legislation to require each railway corporation to file with the Interstate Commerce Commission prior to the date of issuance of any securities a full statement of their character and amount; to furnish to the Commission at such times as it may require full statements of its financial transactions which the Commission may make public at its discretion; and to compile, for the information of its stockholders, such information and in such form as the Commission may require regarding its financial transactions during the fiscal year, and any interests that its direetors may have had in any transaction under investigation; these provisions to he enforced by the Interstate Commerce Commission under appropriate penalties to be fixed by the proposed legislation, including fine and imprisonment. 
tion. When they do not it is a proper function of government to require it. Now, however good the transportation furnished by many American railways may be-and some of them furnish the best in the world-their service, taking them as a whole, is not as safe as it should be, and often has not been adequate. It is usually to their plain interest to make their facilities adequate; without doing so they cannot handle the maximum available business; and without handling it they cannot earn the maximum net return. Legislation to punish people for not doing what it is to their selfish interest to do, and what they are already straining every nerve to do, is futile or harmful. Of this class are the so-called "reciprocal demurrage" regulations adopted in 1907 by several states. Business had outgrown facilities of transportation despite herculean efforts by railway managements. These states in their wisdom fixed penalties to be imposed on the roads for not furnishing needed cars, which did not then exist, but which had been ordered. By the time the cars were built traffic had slumped enormously, and from January to August, 1908, from 200,000 to 400,000 idle freight cars stood upon side tracks. No wise legislature or commission required the shippers to provide freight to load these idle cars; yet it would be just as sensible to require shippers to furnish freight for idle cars when the freight does not exist as to require the railways to fur- 
nish cars to move freight when the cars do not exist.

Regulation has no more important function than that of making railway operation safe. The accident record is the worst feature of railway operation in the United States. Public regulation to reduce it is entirely justified. But knowledge of the causes of accidents is prerequisite to adopting the best means for stopping them; and the national and state governments have done little to get it. The railways are required to report all accidents to the Interstate Commerce Commission, and its statistics are very complete. But the statement that a wreck in which twenty-five people were killed was due to a "butting collision" is not very enlightening. The thing needful to know in order to stop wrecks is not that they occur, but why they occur. Are they due to defects in the rules or equipment of the companies or to disregard or violation of rules by employees? The railway company will naturally blame the employees if it can; and employees just as naturally will blame the company if they can. The only way to get at the truth is through investigations by disinterested government employees. The Interstate Commerce Commission, in the administration of the safety appliances laws, uses inspectors whose duty it is to ascertain if car's are properly equipped; but as they are all taken from the ranks of the railway labor brotherhoods, it is charged that they 270 
cannot be relied on for reports impartial as between employees and employers. ${ }^{2}$ The British Board of Trade uses army officers as investigators; and their thorough and unbiased reports and intelligent recommendations have done much to make the accident record of British railways the envy of the world.

The true causes of accidents being ascertained, the state and federal governments can take salutary action to reduce them. The federal statutes already contain laws intended to promote safety which illustrate both the right and the wrong kind of legislation. In 1893 Congress passed the original safety appliances act. It authorized the American Railway Association to designate to the Interstate Commission the standards of safety appliances to be used, and prohibited any railway engaged in interstate commerce to use after January 1, 1898, any cars or engines not properly equipped. This, it will be seen, put upon the railways themselves the duty of providing safe equipment. The Master Car Builders' Association, an organization composed of railway officers, working in accordance with the spirit of the law, from year to year devised better and better standards which were adopted by most of the roads; and now practically all of the engines and cars on

${ }^{1}$ There is much complaint from railway officers that their reports often are very far from impartial. 
American railways are equipped with good safety appliances. In 1910 Congress amended the law, taking the determination of the appliances to be used out of the hands of the railways and putting it entirely in those of the Commission. It is possible that the Master Car Builders' Association will now discontinue its work of studying and improving the standards. If so, this new federal regulation will prove immediately beneficial, and in the long run very harmful.

Perhaps Congress should pass a law requiring the installation of the block signal system - that is, the system of maintaining a space interval between trains-on all the railways of the United States. Such legislation should not, however, prescribe the kind of signaling system to be used on all roads, or on any; for the specific kind of system that should be used on any road depends entirely on its operating conditions; and therefore the officers of each are best qualified to determine what kind of signal system is best adapted to its needs.

A good deal of the legislation regarding railway operation that is being passed violates every sound principle. This is true, for example, of the laws fixing the number of men that shall be employed in train crews. They originate with representatives of the railway brotherhoods; they are not intended or adapted in any degree whatsoever to promote the public welfare, but are designed to increase the number of men that the railways 272 
must employ; and their effect is directly to in. crease the cost of transportation to the railway and indirectly to increase its cost to the public.

An example of the right kind of regulation of operation is the law regarding the inspection of locomotive boilers passed by Congress in 1911. It does not prescribe in detail how boilers shall be built and kept in good condition. It forbids the railways to use locomotives unless the boilers and appurtenances thereof are in proper condition and safe to operate, and unless they shall be inspected from time to time in accordance with the provisions of the act. The inspections are to be made primarily by the railways in accordance with rules and instructions prepared in the first instance by themselves, but a government chief inspector, two assistant chief inspectors and fifty district inspectors are regularly to check up the roads, and the Interstate Commerce Commission is given authority to exercise general supervision over the carriers to see that the duty of keeping boilers safe, which is primarily imposed on them, is performed.

Laws have been passed within recent years by the nation and some of the states to regulate the hours of service of railway employees. The prohibition by the federal government of trainmen being kept on duty continuously for more than sixteen hours, by a law passed in 1907, was justified; but the insertion in the same act of a provision prohibiting any telegraph operator from being 
kept on duty for over nine hours was absurdly inconsistent. It makes a discrimination between telegraph operators and trainmen that is based on no rational ground. Nine hours, or even eight hours are as many as telegraphers employed in dispatching trains at busy division offices should be kept on duty. But a provision which applies the same rule to station agents in small towns who happen also to perform the duties of telegraph operators, but who are not engaged in telegraph work more than a total of more than two or three hours a day, is not regulation in the interest of public safety, and is just as justifiable, and no more, as regulation to limit similarly the hours of service in banks or stores.

Very different in their nature and effects are the laws and ordinances that have been passed by some states and cities to require the elevation of tracks so as to abolish crossings at grades between different railways, and between railways and highways. Such legislation is in the interest of public safety, and should be enacted and enforced until, in due time, every grade crossing in the country shall be abolished. Inasmuch, however, as highways have been built over railways as often as railways have been over highways, it does not seem fair to make the railways bear all the expense.

A number of states have passed laws to require $t$ te use of locomotive headlights having such great 274 
power that only electric headlights will meet the requirements. Professor C. H. Benjamin, of Purdue University, as a result of an investigation he made, contends that the use of high-power headlights on lines where there are block signals, tends to prevent engineers from properly reading the signals and increases the danger of accident. On the other hand, other experts and many railway officers believe that high-power headlights promote safety both on roads having block signals and on those not having them. The fact that experts so entirely disagree shows conclusively that no legislation should be passed regarding the use of high-power headlights. In the State of South Dakota, in 1910, the question of whether railways should be required to use electric headlights was submitted to a referendum vote of the people! The people, wiser than the legislators, refused to pass the law. The fact that such a measure could be submitted to a referendum vote illustrates the absurd lengths to which regulation of railways is sometimes carried.

A good many laws are being passed which require the doing of things which perhaps ought to be done, but which ought not to be required by law to be done, because the matters with which they deal are of such little public moment that the doing or not doing of them should be left to the discretion of railway officers. The laws passed by the state legislatures in the spring of 1911 contain 
provisions, for example, regarding not only the number of men that must be employed in train crews, but also regarding the railway experience employees must have had. The purpose of this is to strengthen the labor monopolies of the railway unions and embarrass the railway managements in case of strikes. Other provisions relate to the number of hour's per day that railway employees may be required to work; the kind of letters of recommendation they shall be given when they quit or are discharged; the sort of uniforms they may be required to wear; the kind of cabooses the railways shall use; the way they shall inspect their boilers; the kind of headlights and safety appliances on cars that they shall use; the places where they shall stop their passenger trains, and the way that they shall equip them; the speed of iive-stock and "dead freight" trains; the way switchlights shall be set; the minimum clearances between cars and structures near the tracks; the kind of scales that railways shall have and the way that they shall weigh shipper's' goods; the way they shall fence their right of way and burn weeds along it; the way they shall drain their roadway; the construction of double tracks; the equipment of stations, stock yards, shops, etc. In 1909 forty-one State Legislatures passed 664 provisions, and in the spring of 1911 forty State Legislatures passed 276 provisions, affecting railways. When it is considered that Congress and the legislatures had 276 
passed 800 provisions affecting railways in the five years 1904-1908, inclusive, and that numerous such laws have been passed since, one is disposed to wonder if there can be many subjects pertaining to transportation left for the lawmakers to deal with!

This list of statutory provisions regarding railways recalls the striking language used by the German historian Von Holst in describing the allpervading activities of government in France just prior to the Revolution. After referring to the functions of the controller general, who, he said, was the center around which everything turned, he added:

What the controller was for the whole state the intendant was for its administrative subdivision-the généralité. He had his hand in everything and always in the spirit of bustling, distrustful and presumptuous paternalism. ... Surely this government machinery was simple enough, - ay, it was of fearful, paralyzing, nay, absolutely killing, simplicity. . . . The capability for self-government was systematically annihilated. And it was done so successfully that the people at last could not get enough of this kind of paternalism. We meet with bitter complaints that, in regard to one thing or another, the government had not marked out the way with sufficient clearness and strictness. . . . As the government charged itself with attending to everything it was, of course, also held responsible for everything. Commanding, instructing, or at least ad- 
vising, in regard to everything, was it not also its duty to foresee everything, up to the fancies of fashion, the whims of trade, the freaks of the weather? The government became the terrestrial Providence. One of the attributes of Providence is omnipresence. If we merely look at the intendants and their subordinates, who did nearly all the real governing, we get but a very inadequate idea of how far government under the ancient régime came up to this requirement. . . . There was such an innumerable host of all sorts of public officials that one is tempted to say whatever a man did he was almost as sure to have some kind of a public functionary at his side as he was to be followed by his own shadow. If the peasant brought an ox to market the inspector of eattle presented himself; the inspector of calves looked after the calves; the inspector of swine took care of the pigs; and if it happened to be a sow with young he was joined by the inspector of sucking pigs. ${ }^{1}$

Students of history know the great reaction that took place throughout the civilized world late in the eighteenth and early in the nineteenth century against this sort of governmental paternalism. Buckle, in his "History of Civilization in England," published in 1857, expressed the prevalent view of that period.

Every great reform which has been effected, has consisted not in doing something new, but in undoing

1 “The French Revolution," by Von Holst, Vol. I, page 11. 278 
something old. The most valuable additions made to legislation have been enactments destructive of previous legislation; and the best laws which have been passed have been those by which former laws were repealed. ... The whole scope and tendency of modern legislation is to restore things to that natural channel from which the ignorance of preceding legislators has driven them. . . . It is clear that the progress of civilization cannot be due to those who on the most important subjects have done so much harm that their successors are considered benefactors simply because they reverse their policy and thus restore affairs to the state in which they would have remained if politicians had allowed them to run on in the course which the wants of society required.

If we carry government regulation of railways and other industries to an extreme the effects will be so evil that either we will resort to state socialism, or another wave of reaction will sweep the regulatory laws, good as well as bad, from the statute books, and some future historian will say, as Buckle said, that the most valuable additions to the legislation of that time are enactments destructive of the legislation of our time.

"Virtue," says Aristotle, "is a middle state between two faulty states, in the way of excess on one side and defect on the other; and it is so, moreover, because the faulty states on one side fall short of, and those on the other side exceed, what is right." To make government regulation 
of railroads fair and successful, the faulty state on the side of the reactionary that would fall short of, and the faulty state on the side of the radical that would exceed, what is right, must equally be avoided. No right of the public should be left unprotected. But no restriction or burden that the protection of the rights of the public does not clearly require should be placed upon the railroad. 
I N D E X

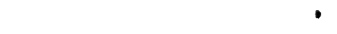





\section{N D E X}

ACcidents, railway, 166.

at highway crossings, 172 . to employees, $128,166$.

to passengers, 128, 166.

to trespassers, 167.

Act to Regulate Commerce, on discrimination, 46.

recommendations for amendments to, 75,76 .

Acworth, W. M., comparison of American and British railway management by, 138 .

on efficiency of American railways, 142 .

Antitrust Act, Sherman, 73.

BELgIUM, costs of rail and water transportation in, 197-201.

length and tonnage of waterways in, 185.

traffic in, rail and water, increase of, 185.

Brandeis, Louis D., on efficiency of American railways, 124.

on railway profits and efficiency, 105.

Buckle, Henry Thomas, on relations of government and business, 278.

Bulk, influence of, on rates, 14 .
CAPACITY of freight cars, 139.

Capitalization of railways, in foreign countries, 112, 130.

in the United States, compared with their cost, 129.

compared with their valuation, 113.

influence of, on rates, 114 .

"Charging what the traffic will bear," $9,22,26$.

examples of, 55 .

Classification, freight, 14. and discrimination, 47.

Commerce Court, 245.

Commissions, railroad, A. T. Hadley on powers of, 234.

personnel of, 235 .

salaries of members of, 238.

Competition, and discrimination, Martin A. Knapp on, 72.

between railways, 58 . between railways and inland waterways, 206.

between railways and transoceanic routes, 178.

influence of, on rates, 28 . Competitive traffic, rates on, 9. 


\section{INDEX}

Cooley, T. M., on conflict of state and interstate regulation, 229.

Copper, rates on, 64.

Cost, of labor and of commoditjes, increases in, 142.

of rail and of water transportation, 181.

of transportation on Erie Canal, 201.

of transportation on foreign railways, 197.

"Cost of Service" in ratemaking, 1, 13.

additional, 6 .

difference between additional and average, 16.

Halford Erickson on, 25. impossible to use as sole basis for rates, 23 .

Cost accounting, use of, in ratemaking, 17.

DENSITY of traffic, on railways, in different sections of the United States, 54.

in the United States and foreign countries, 12 , $218,219$.

on foreign waterways, 218.

Depth, of American waterways, 189.

of foreign waterways, 187 .

Discrimination, Act to Regulate Commerce on, 46 .

hetween commodities, 47 .

between commodities and communities, 42.

between communities, 53 .
Diserimination, between rates on live-stock and packing-house products, 50 . between shippers, 62 . by substitution of tonnage at transit points, 68 . by tap line allowances, 67 . caused by waterways, 213 . difference between fair and unfair, 42.

effect of, 49.

in the railway and other industries, 43.

in rates on copper, 64 .

Martin A. Knapp on, 72. remedies for, 71 .

Distance, basing rates on, 38 . rates not made in proportion to, 8,26 .

ECONOMY, as related to efficiency, 124.

of railway operation in the United States and Europe, 134 .

Efficiency, effect of regulation of profits on, 101, 105, 123.

from the standpoint of economy, 124.

from the standpoint of public service, 153.

of railway employees, 148 .

of railway equipment, 138 . Employees, accidents to, 128, 166.

efficiency of, 148. number of, in United States, 166. 


\section{INDEX}

Equipment, efficiency of, 138. France, operating expenses

Erickson, Halford, on cost of service in ratemaking, 25.

Erie Canal, cost of transportation on, 201.

“Fair Return," limiting earnings to, v, 85, 103, 258.

Railroad Securities Commission on, 123.

United States Circuit Judge Sanborn on, 100.

Finances, regulation of, 258.

Fink, Albert, on variations in cost of service, 23.

Fixed charges, contributions to, from low grade freight, 6 .

France, average freight rate in, 12.

average haul per ton of freight in, 134.

average passenger rate in, 84.

capitalization of railways in, $112,136$.

cost of waterways per mile in, 200.

density of traffic in, on railways, 12.

on waterways in, 218.

freight hauled in, per dollar of capital, 136.

per dollar of operating expenses, 136.

length and tonnage of waterways in, 185. per mile of road in, 136.

passengers hauled in, per dollar of capital, 136.

per dollar of operating expenses, 136.

public service rendered in, per dollar of capital, 136 .

per dollar of operating expenses, 136.

Freight, average hauls of, in United States and foreign countries, 134.

car capacity in Europe and United States, 138.

hauled per dollar of capital in United States and foreign countries, 136 . hauled per dollar of operating expenses in United States and foreign countries, 136.

rates per ton per mile in United States and foreign countries, 12, 197. trains, fast, in the United States and foreign countries, 162.

GERMANY, average freight rate in, 12 .

average haul per ton of freight in, 134.

average passenger rate in, 84.

capitalization (cost of construction) of railways in, $112,136$. 


\section{INDEX}

Germany, cost of waterways per mile in, 200. density of traffic in, on railways, 12.

on waterways, 218.

freight hauled in, per dollar of capital, 136.

per dollar of operating expenses, 136.

length and tonnage of waterways in, $186,187$.

operating expenses per mile of road in, 136. passengers hauled in, per dollar of capital, 136.

per dollar of operating expenses, 136.

public service rendered in, per dollar of capital, 136.

per dollar of operating expenses, 136.

Government regulation, by commissions or legislatures? 232.

Hadley, A. T., on, 234.

of finances, 258.

of operation, 268 .

of rates, 251.

state vs. federal, 228. underlying principles of, 246.

who shall regulate? 222 .

HADLEY, A. T., on "charging what the traffic will bear," 9 .

on railway regulation, vii, 234.
Harrison, Fairfax, on valuation and ratemaking, 116.

Haul, freight, average per ton in United States and foreign countries, 134 .

Hill, James J., and making of Northwestern lumber rates, 30 .

Holst, H. Von, on excessive government regulation in France, 277.

INCREASING returns, law of, 6 . Interstate commerce, T. M. Cooley on future of regulation of, 229.

state interference with, 229.

Judge W. H. Sanborn on, 231.

Interstate Commerce Act, on discrimination, 46.

recommendations for amendment of, 75, 76 .

Interstate Commerce Commission, conflicting duties of, 241.

personnel of, 239 .

power needed by, to prevent unfair discrimination, 76 .

JoHNSON, Emory R., on effects of pooling, 73, 74 .

KAISER Wilhelm Canal, cost of, 201.

Knapp, Martin A., on competition and discrimination, 72. 


\section{INDEX}

Kruttschnitt, Julius, on rail- Passenger rates, in foreign way efficiency, 142. countries and United States, 84.

LABOR, increases in wages of, Passenger service, in United 142.

Long-and-short haul, effects of stringent rule on, in Iowa, 59.

rates on, 58.

States compared with that in foreign countries, 155.

safety of, 128, 166.

terminals and, 154 .

Lumber rates, Northwestern, 30 .

Madison, James, on accumulation of all governmental power in the same hands, 240.

Maximum rate possible to charge, 26.

McPherson, Logan G. , on transportation in Europe, passenger, 156.

waterway, 188.

Monopoly, industrial, 45. railway, 44.

Morris, Ray, "Railroad Administration,"' 259, 261.

NORTHWESTERN lumber rates, 30.

Operating expenses per mile of road in United States and foreign countries, 136.

Operation, differences in average costs of, 24, 54 . regulation of, 268 .

PACKING-HOUSE products, discriminatory rates on, 50 .

Passengers, accidents to, 128 , 166.

hauled, per dollar of capital in United States and foreign countries, 136. per dollar of operating expenses in United States and foreign countries, 136.

Physical valuation, as a basis for fixing rates, 81,122 . Pooling, 72 .

Emory R. Johnson on, 73, 74.

Pratt, Edwin A., on American passenger service, 155.

Profits, valuation and, 123.

Prouty, Charles A., on conflicting duties of Interstate Commerce Commission, 243.

on regulation of railway capital, 225.

Public service rendered, per dollar of capital in United States and foreign countries, 136 .

per dollar of operating expenses, 136. 


\section{INDEX}

IRALROAn Securities Commission, report of, 122, 267.

liatemaking, principles of, 1 , 19.

cost of service, 1.

value of service, 19 .

Rates, effect of unreasonably low, 53.

freight, in United States and foreign countries, 12 , 197.

on foreign waterways, 197.

influence of bulk on, 14 . long-and-short haul, 58. maximum possible, 26. on competitive traffic, 9 . on copper, 64 .

on corn in Illinois, 26.

on grain, 65 .

on live-stock and packinghouse produets, diserimination between, 50 . on low grade freight, 6 .

on Northwestern lumber, 30 . passenger, in the United

States and foreign countries, 84.

regulation of, 251.

similarity of, to taxes, 33 .

Regulation, for increasing

safety of transportation, 270.

government, underlying principles, 246.

who shall regulate? 222. of finances, 258 . of operation, 268. of rates, 251 .
Return, limiting railways to a maximum, 107.

Ripley, E. P., on " charging what the traffic will bear," 10.

Ripley, W. Z., on ratemaking, 26.

SAFETy, railway, 128, 166.

Sanborn, Judge W. H., on "fair return," 100.

on railway valuation, 87,91 . on state interference with interstate commerce, 231.

Sault Ste. Marie Canal, cost of, 201.

interest on investment per ton mile of freight carried, 202.

Securities Commission, Railroad, report of, 122, 267.

Sherman Antitrust Law, 73.

State railroad commissions, A. T. Hadley on powers of, 234.

personnel of, 235 .

salaries of members of, 238 .

Substitution of tonnage at transit points, 68 .

Suez Canal, cost of, 201.

Switzerland, average haul per ton of freight in, 134.

eapitalization of railways in, 112.

freight hauled in, per dollar of eapital, 136.

per dollar of operating expenses, 136. 


\section{INDEX}

Switzerland, operating ex- United Kingdom, public serpenses per mile of road in, 136 .

passengers hauled in, per dollar of capital, 136.

per dollar of operating expenses, 136.

public service rendered in, per dollar of capital, 136. per dollar of operating expenses, 136.

"TAP LINE" railways, allowance of excessive rate divisions to, 67 .

Terminals, passenger, 154.

Transit privilege, abuse of, 68 . Trespassers, accidents to, 167.

UNITED KINGDOM, average haul per ton of freight in, 134.

average passenger rate in, 84.

capitalization of railways in, 112.

freight hauled in, per dollar of capital, 136 .

per dollar of operating expenses, 136.

operating expenses per mile of road in, 136.

passengers hauled in, per dollar of capital, 136.

per dollar of operating expenses, 136.

public service rendered in, per dollar of capital, 136.

vice rendered in, per dollar of operating expenses, 136.

Valuation of Railways, decision regarding, in Minnesota, by United States Circuit Judge Sanborn, 87, 91.

for regulating rates and profits, 81, 123.

Harrison, Fairfax, on, 117. peculiar difficulties of, 116 . views of Railroad Securities Commission on, 122. "'Value of Service," in railway ratemaking, 4, 19, 46 . in ratemaking and pricemaking in other industries, 19.

WATER transportation, costs of rail and, 181.

Waterways, as auxiliary facilities of transportation, 216.

as regulators of railway rates, 206.

competition of, with railways, 206. cost of, in France, 199.

in Germany, 199.

of Kaiser Wilhelm Canal, 201.

of Manchester Ship Canal, 201.

of Sault Ste. Marie Canal, 201. 


\section{INDEX}

Waterways, cost of, of Suez Waterways, length of, and Canal, 201. ber mile, 200.

density of traffic on, in Europe, 218.

depth of American, 189. depth of European, 187. tonnage on, foreign, 185.

rates per ton per mile on foreign, 197.

transoceanic, competition of, with railways, 178 .

(2) 



This hook is I)UI: on the last date stamped below

\section{MAR 191935}

DEC $? 0^{1949}$

Firm L-9-15\%11, 27 
Qtices.Wagne

AA 0010059293

$$
\begin{gathered}
H E \\
203 \\
092 a
\end{gathered}
$$


